\title{
Peter Tomory
}

\section{the New Zealand years, 1956-1968}

Courtney Johnston

A thesis submitted in fulfillment of the requirements for the degree of Master of Arts in Art History

Victoria University of Wellington 2004 


\section{Contents}

Abstract

Acknowledgments

Abbreviations $\quad$ iii

Peter Tomory's principal texts iv

List of illustrations viii

Introduction

I Peter Tomory and the Auckland City Art Gallery 11

II The permanent collection $\quad 41$

III Temporary exhibitions $\quad 73$

IV Peter Tomory and New Zealand art history 111

$\begin{array}{ll}\text { Conclusion } & 169\end{array}$

Bibliography

i Unpublished sources $\quad 174$

ii Peter Tomory's published writings 177

iii General bibliography 186 


\section{Abstract}

This thesis concerns Peter Tomory's nine years as Director of the Auckland City Art Gallery, between 1956 and 1964. The main theme that emerges in this study concerns the emphasis Tomory placed on professional practices, both at the Gallery and in the visual arts in New Zealand as a whole.

The discussion is broken into four chapters. The first chapter sets the cortext for Tomory's directorship: his professional background, the New Zealand art world of the 1950s, and his initial vision for the Gallery. The second chapter is devoted to Tomory's development of the Gallery's permanent collection, and the third explores the ambitious programme of temporary exhibitions undertaken at the Gallery during his tenure. These broad topics are considered with reference to Tomory's policy statements, and through the close study of selected case studies. The final chapter examines the history of New Zealand art that Tomory developed over his twelve years in New Zealand (including both the texts he published while at the Gallery, and those he wrote while lecturing at the University of Auckland School of Fine Arts from 1965 to 1968) and his call for a more professional approach to art writing in this country. A bibliography of Tomory's published texts is included.

A special effort is made in this study to consider Tomory's activities at the Gallery and his writing within their original historical and art-historical contexts, and also with reference to the way these actions and texts have been interpreted and employed by later commentators, especially post-nationalist critics. In this way, it is revealed that the history of New Zealand art formulated in the 1950s and 1960s was less homogenous, more complex and more contentious than it has more recently been portrayed. 


\section{Acknowledgements}

My first thanks go to the Art History staff members and others who have supported me as I undertook this thesis. In particular, I should like to thank my supervisor, Roger Blackley, for his generosity, good cheer and editorial acumen. I would also like to thank Tina Barton (who initially pointed me in the direction of this topic), Robert Leonard, Aaron Lister, William McAloon, Rebecca Rice and Damian Skinner for their interest in and assistance with this project. I am tremendously grateful for my family's encouragement and support.

I was greatly aided in my research by the following people: Catherine Hammond at the Auckland Art Gallery Toi o Tãmaki Research Library; Patrick Jackson at the Auckland City Council Archives; Julia Collieu at the New Walk Museum and Art Gallery, Leicester.

I would like to make particular acknowledgement of Gordon H. Brown, Hamish Keith and Peter Webb. Gordon shared with me his memories of the Tomory era, and his meticulous research into the growing professionalism in art gallery management in New Zealand the 1950s and 1960s has been of great assistance. Hamish's memories of his time at the Auckland City Art Gallery between 1958 and 1970 have given colour and detail to my understanding of the staffing and operation of the Gallery, and Peter contributed his insight as a staff member during both Eric Westbrook's and Tomory's tenures.

My most sincere thanks are reserved for Peter Tomory, who gave me his support for this project and provided me with invaluable assistance. This thesis is dedicated to Peter Tomory, in recognition of his immense contribution to the visual arts in New Zealand. 


\section{Abbreviations}

\section{Footnotes}

As this thesis is concerned largely with the analysis of written sources, there are a significant number of footnotes. For this reason, footnotes are not numbered continuously, but begin afresh within each of the five sections.

\section{Short titles}

When a text is repeatedly referenced, a short title is used in the footnotes in preference to 'op. cit.'. The short title is given at the end of the first full reference.

\section{Abbreviations within the footnotes and bibliography}

Within the footnotes and bibliography, the following abbreviations are used:

$\begin{array}{ll}\text { AAG archives } & \text { Auckland Art Gallery Toi o Tāmaki Archives } \\ \text { ACC archives } & \text { Auckland City Council Archives } \\ \text { AGMANZ } & \text { Art Galleries and Museums Association of New Zealand } \\ \text { Listener } & \text { New Zealand Listener } \\ \text { NZH } & \text { New Zealand Herald } \\ \text { Star } & \text { Auckland Star }\end{array}$

\section{Auckland City Art Gallery}

The Auckland Art Gallery Toi o Tāmaki was known as the Auckland City Art Gallery during the period under study (although it was also referred to as the 'Auckland Art Gallery' and the 'City Art Gallery'). The Auckland City Art Gallery is called 'the Gallery' throughout this text, except on those occasions where for the sake of clarity its full title or the description the 'Auckland Gallery' is used.

\section{Anne Kirker's interview with Peter Tomory, 25 December 1985.}

The original interview (on two cassette tapes) is held at the Museum of New Zealand Te Papa Tongarewa archives. The interview was published in an edited form in two issues of Art New Zealand in 1986. Both the unpublished and published versions are referred to throughout the text, and are differentiated in the footnotes. 


\section{Peter Tomory's principal texts}

A full list of Tomory's published writing is included in the bibliography. Those of 'Tomory's published writings referred to most frequently in this thesis are abbreviated as follows: a short summary of these texts is also provided.

\section{Tomory, New Zealand painting (1956).}

Peter Tomory's catalogue essay for New Zealand painting: an exhibition arranged by the Auckland City Art Gallery and the Auckland Society of Arts on the occasion of the 1956 Auckland Festival of the Arts, Auckland: Auckland City Art Gallery, 1956.

This is Tomory's first text of significant length written in New Zealand, and his first attempt at mapping the development of art in this country. The exhibition brought together New Zealand painting from the mid-19th century to the present, with the goal of determining whether any stylistic trends could be seen to have developed in this hundred-year period. In his catalogue essay, Tomory discussed early artists' attempts to master the new landscape, the exodus of artists to Europe between 1900 and 1930 and the impact of this exodus on the development of modern New Zealand art. He gave his opinion of several earlier New Zealand artists, but did not discuss contemporary art except to express a hope that New Zealand would soon see the development of independent artistic styles and conceptions.

\section{Tomory, Landfall (1958).}

Peter Tomory, 'Looking at art in New Zealand', Landfall 46, vol. 2, no. 2, 1958, pp. 153169.

This essay, broken into three sections but intended to be read as a whole, is the published version of a series of three radio talks Tomory gave in 1957. In the first part Tomory described how aesthetic sensibilities are shaped by visual experience. He argued that New Zealanders had, over the previous century, developed a different aesthetic sensibility to Europeans, through the combination of their lack of exposure to great works of European art and the visual impress of the landscape in this country. The second part dealt with the experience of viewing paintings. In this section, Tomory made clear distinctions between 'serious' art and art which was merely 'illustration'. In the third part Tomory gave his assessment of New Zealand art criticism, asserting that the poor state of criticism in this country, written by amateurs whose main concerns lay with New Zealand literature, meant that viewers had become accustomed to illustrative painting-especially the New Zealand school of neo-romantic painting-and found serious art hard to understand. In addition to criticising the use of conventions drawn 
from British neo-romantic painting in order to depict the New Zealand experience, Tomory also criticised those artists who mimicked European primitivism by incorporating Maori motifs in their work.

\section{Tomory, Connoisseur (1959).}

Peter Tomory, 'Unifying art-in New Zealand', Connoisseur, May 1959, pp. 9-11.

This article was written by invitation of the editor, who in an introductory note expressed sympathy for the limitations that had been forced on the Gallery by the Government's import restrictions of the late 1950s. Tomory here discussed his intention to build a collection at the Gallery that would educate the audience, and would show the development of New Zealand art within the wider context of European art history. Tomory also described the theory (which could broadly be called 'regional') that underpinned his selection of works for the collection.

\section{Tomory, Distance (1961).}

Peter Tomory, 'The visual arts' in Keith Sinclair (ed.), Distance looks our way: the effects of remoteness on New Zealand, Auckland: Paul's Book Arcade for the University of Auckland, 1961, pp. 63-78.

The essays in this anthology were first given as a series of lectures that debated the proposal: 'although New Zealand is/was physically remote, is/was it isolated?' Tomory's contribution opened with an evocation of the negative effect of remoteness on Maori culture, which was purportedly in decline by the time of European arrival. In the body of the essay, Tomory used Theodor Lipps' theory of Empathy to distinguish the 'three distinct strata of attitude' of early settler society and describe the ways in which these attitudes determined distinctly different approaches to the depiction of the new land. Tomory used this theory to separate what he believed to be 'illustrative' depictions of New Zealand subjects from those he believed arose from 'sensuous' or 'feeling' responses to the land.

In this essay Tomory built on the structure he had first outlined in 1956. He described a history of New Zealand art with three periods: the early topographical artists; the emergence of a modern movement (triggered by the arrival of artists such as Petrus van der Velden) in the 1890 s and its subsequent stagnation in the first 30 years of the twentieth century due to the exodus of New Zealand-born artists to Europe and Australia; the re-emergence of the modern movement in the 1930s in the work of artists (led by Angus, Woollaston and McCahon) prevented from leaving the country by first the depression and then the Second World War. 


\section{Tomory, Contemporary painting (1964).}

Peter Tomory's catalogue essay for Contemporary painting in New Zealand, Wellington: Queen Elizabeth II Arts Council of New Zealand, 1964.

In 1964 Tomory assisted in the selection of works for Contemporary painting in New Zealand, the first officially sponsored exhibition of such work to be shown in London. In the catalogue Tomory positioned New Zealand and New Zealand art in relation to the Pacific and particularly to America, arguing that New Zealand no longer looked towards Britain for guidance. He reiterated his three-stage formulation of the history of New Zealand art, but distanced himself from the idea of a national school of painting. He firmly located Angus, Woollaston and McCahon as New Zealand's senior modern artists, but pointed to the selection of a number of younger artists with diverse painting styles as an indication of the maturation of New Zealand painting since the 1940s.

\section{Tomory, Ascent (1968).}

Peter Tomory, 'Imaginary reefs and floating islands: the romantic image in New Zealand painting', Ascent, vol. 1, no. 2, July 1968, pp. 5-19.

Tomory's 1967 lecture to the Auckland City Art Gallery Associates, 'Imaginary reefs and floating islands', was published in Ascent in 1968. In his most complex piece of writing, Tomory used a metaphor drawn from an essay by Ortega y Gasset to examine the romantic image in New Zealand painting. He discussed the theme of the profile in relation to topographical works and the work of the first romantic artists to depict New Zealand, and asked how one could separate topographical works from those that were 'sensuous and imaginative identifications' with the land. The text also includes assessments of the work of McCahon, Angus and Woollaston.

Tomory, Painting 1890-1950 (1968).

Peter Tomory, Painting 1890-1950, Wellington: A.H. \& A.W. Reed, 1968.

Painting 1827-1967 consists of three short books: Hamish Keith's Painting 1827-1890, Tomory's Painting 1890-1950 and Mark Young's Painting 1950-1967, all edited by Tomory. Tomory here undertook a new consideration of the sources of the modern movement in New Zealand painting. In this text, Tomory emphasised the artists already practising in New Zealand before 1890, locating the impetus for the modern movement in their example rather than attributing it to the immigrant artists who arrived in the 1890s. He placed less emphasis on the exodus of artists between 1900 and 1930, instead dwelling on those artists who remained in or returned to New Zealand during this period, and also considered the emergence of an arts infrastructure at this time. In this text Tomory examined the historical development of stylistic responses to the New 
Zealand environment. He described how the artists who arrived in the 1890s adapted their styles in response to the characteristic landforms and light of New Zealand, considered how Perkins' introduction of British neo-romanticism affected painting in this country, and concluded with a discussion of the differences and similarities he saw in the painting of Woollaston, Angus and McCahon.

\section{Tomory, Pattern (1968).}

Peter Tomory, 'Art' in A.L. McLeod (ed.), The pattern of New Zealand culture, Melbourne and New York: Oxford University Press and Cornell University Press, 1968, pp. 176-208.

In this essay Tomory reiterated his three-stage history of New Zealand art, but his narrative reflects the same changes in thinking that inform Painting 1890-1950. Tomory here emphasised the proliferation of styles in contemporary New Zealand art, and described the emergence of a new generation of artists less concerned with depicting the landscape. This is a similar observation to that which he put forward in the 1964 Contemporary painting in New Zealand catalogue. This emphasis on urbanisation and New Zealand's place in the world is significant in that both that catalogue and The pattern of New Zealand culture were intended for an international audience. In the second half of the essay Tomory briefly considered other artistic practices-sculpture, typography and ceramics, for example-and gave thumbnail sketches of the activities and collections of New Zealand's four major public art galleries.

\footnotetext{
1 The pattern of New Zealand culture was the fourth in a series of books published by Cornell University Press that presented the cultures of post-colonial countries. The first three books dealt with America, Canada and Australia.
} 


\section{List of illustrations}

Leonard Mitchell, Portrait of Peter Tomory, 1956

Peter Tomory and Colin McCahon at the

Auckland City Art Gallery, c. 1957

Karl Schmidt-Rottluff, Melancholy, 1914

Installation of contemporary New Zealand

painting, Auckland City Art Gallery, c. 1959

Georges Rouault, Nude in profile, 1936

The sculpture court at the Auckland City

Art Gallery, c. 1957

Installation of Rouault's Miserere series at the Auckland City Art Gallery, 1957

Exhibition of contemporary New Zealand sculpture, Auckland City Art Gallery, c. 1959

J.C. Hoyte, An Auckland panorama, 1869, on the cover of the Auckland City Art Gallery Quarterly, no. 3, 1957 following page viii

following page 33

following page 54

following page 57

following page 67

following page 68

following page ' 77

following page 88

following page 97 


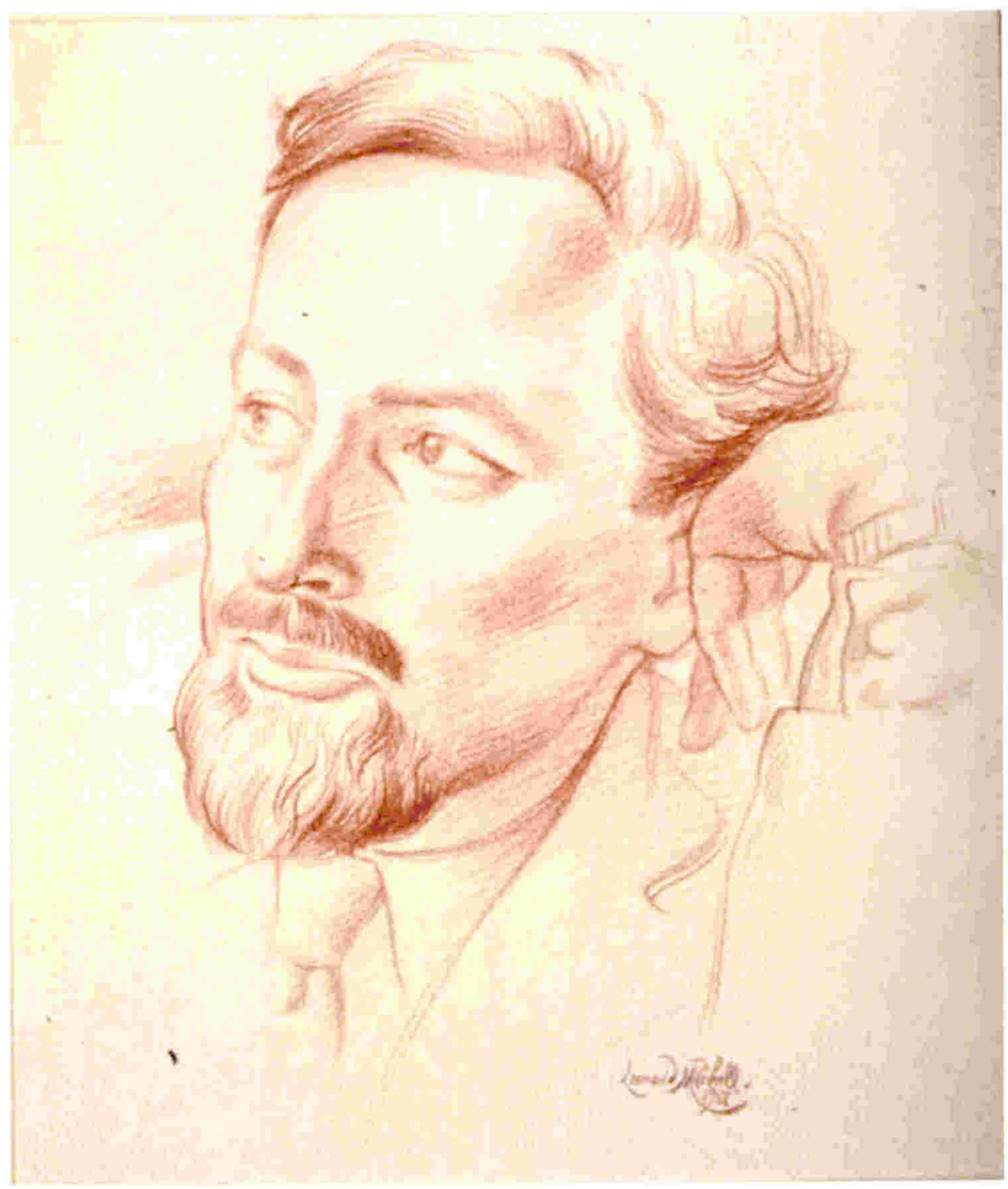

Leonard Mitchell, Portrait of Peter Tomory, 1956, conté, 350 × 300 mm, collection of the Auckland Art Gallery Toi o Tāmaki, purchased 1990. 


\section{Introduction}

In 1951 the Auckland City Council announced that it had decided to form the new position of Director of the Auckland City Art Gallery and to advertise for applicants. The Gallery was opened in February 1888, and since 1913 had been managed by John Barr, Auckland's city librarian, who also had responsibility for the Old Colonists Museum. The successful candidate in 1951 was Eric Westbrook, a young Englishman; trained as a painter, Westbrook had also directed the Wakefield Art Gallery, and had most recently worked for the Arts Council of Great Britain. Westbrook was the first professionally trained director appointed to a New Zealand public art gallery. His aim in Auckland was to make the Gallery a vibrant part of the city's life; highlights of his tenure included securing Auckland City Council funding for acquisitions, the formation of a dedicated Frances Hodgkins collection and the establishment of the Auckland Gallery Associates in 1954. Westbrook left the Gallery in 1955 to take up the directorship of the National Gallery of Victoria, Melbourne; his successor in Auckland was Peter Tomory, who in this way became New Zealand's second professionally trained gallery director.

The Gallery was, and continues to be, principally funded by the Auckland City Council. During his tenure, Tomory reported to the Parks and Library Committee of the City Council, headed in 1956 by Mary Dreaver and from 1957 by F.N. Ambler. The Committee was composed of City Councilors and co-opted members who acted as advisors on artistic matters. In 1956 these co-opted members were Auckland architect Vernon Brown and Pascoe Redwood, chairman of the Auckland Society of Arts. In 1957 Brown and Redwood were replaced by architect Geoffrey Rix-Trott, who was joined in 1963 by another 
architect, John Stacpoole. In addition to the City Council collection, the Gallery also housed the Mackelvie Trust collection, administered by the Mackelvie Trust Board, which was headed at the time of Tomory's appointment by Richard O. Gross, and from 1957 by Rix-Trott. In addition to the ongoing acquisition of works by the Mackelvie Trust, the Art Gallery Associates (now known as the Friends of the Gallery) were at this time, and continue to be, a significant source of support to the Gallery and generous donors to the collection.

This thesis grew out of research conducted in 2001 for my art history honours paper, 'Tomory's texts: a discussion of Peter Tomory's New Zealand writings, 1956-1968', at Victoria University of Wellington. In that paper, I concentrated on a close reading of seven of Tomory's key New Zealand texts, examining his assessment of New Zealand art criticism, his influence on the developing canon of modernist New Zealand artists and his formulation of a history of New Zealand art. ${ }^{1}$ I chose to focus on Tomory's role as a writer and critic, and did not extend my research into his role as director at the Auckland City Art Gallery. My research for this paper left me with a number of unanswered questions, a deep curiosity about the period I had studied, and certain misgivings about the way that it has been viewed in more recent years.

This thesis extends that original research by taking a fuller view of Tomory's time in New Zealand. It focuses on the nine yed that Tomory spent as director at the Gallery, from 1956 to 1964 . The discussion is broken into four

\footnotetext{
1 'Tomory's texts: a discussion of Peter Tomory's New Zealand writings, 1956-1968' is available in the art history disciplinary library at Victoria University of Wellington. The seven texts I examined in this paper are the same as those outlined in the section of this thesis titled 'Peter Tomory's principal texts'. with the exception of the essay published in the Connoisseur, which I became aware of only after Peter Tomory alerted me to it in 2002 .
} 
chapters, the first three of which examine areas that were omitted from my honours paper. The first chapter sets the context for Tomory's directorship: both his own background, and the New Zealand art world that he encountered upon his arrival in Auckland. It discusses Tomory's first reactions to the New Zealand art scene, and his initial vision for the Gallery.

The second chapter considers Tomory's management of the Gallery's permanent collection. In addition to examining Tomory's collection policy, the display of the collection and areas of the collection that show Tomory's influence, this chapter also investigates how the Gallery went about acquiring work, and especially how New Zealand's distance from European art markets was negotiated. A major theme of this chapter-and indeed, of this thesis-is the gradual movement from the direct governance of New Zealand's public art galleries by the municipal body that funded them, via a (usually untrained) committee, to the appointment of professionally trained staff who were given significant autonomy in developing and applying policy. The ramifications of this shift are explored, using as a case study the controversy surrounding the purchase of Barbara Hepworth's Torso II in 1963.

The third chapter looks at the Gallery's programme of temporary exhibitions by way of a series of case studies. During Tomory's tenure, the Gallery assumed responsibility for managing most of the touring shows of visual art which came to New Zealand; these shows are considered, with special emphasis on the influential 1958 exhibition British abstract painters. Tomory was strongly opposed to showing amateur work at the Gallery, and his opinions on this issue are investigated by focusing on his continued opposition to hosting the Kelliher Prize exhibition. Although Tomory appears to have been initially somewhat diffident regarding New Zealand art-and reluctant to allow the Gallery to become the home of the local artist - this chapter traces how the 
Gallery during this period became increasingly supportive of contemporary New Zealand art, and also nurtured the series of shows of historical New Zealand art initiated by Westbrook. The chapter closes with a discussion of the important 1961 exhibition Painting from the Pacific.

The fourth chapter, on Tomory's writing on New Zealand art, is an extension of the research I conducted in 2001. It takes into consideration numerous texts omitted from my honours paper, examines more closely the sources that inform Tomory's writing, and tackles more vigorously the way that Tomory's texts have been characterised by art historians in the 1980s and 1990s. The discussion moves beyond Tomory's time at the Gallery, as it encompasses the texts that he wrote between 1965 and 1968, when he was senior lecturer in art history at the University of Auckland. The chapter begins by tracing the history of New Zealand art that Tomory developed over 12 years of writing on the topic, and examines the theory that shaped it. The reception of Tomory's writing by later art historians (especially by Gordon H. Brown and Hamish Keith in their 1969 book An introduction to New Zealand painting 1837-1967, and by later revisionist writers) is then explored, together with a consideration of Tomory's emphasis upon regionalism. Tomory was also concerned with the quality of New Zealand's art criticism, and his writing on this topic is examined, as is Francis Pound's reading of these texts.

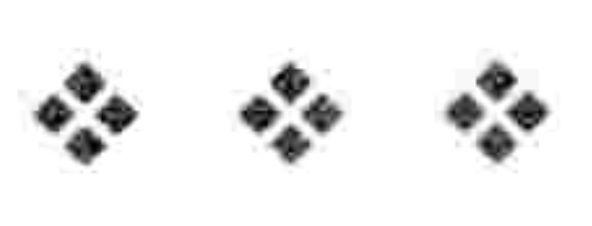

Much of the material presented in this thesis will be known to a reader familiar with the period under study, as it has been re-presented in previous analyses of the period, often undertaken in an effort to revise and de-mythologise what has come to be termed the 'Nationalist' period of our art history. I am part of a 
generation of art history students who learnt of the 1950s and 1960s by way of the revisionism of the 1980s and 1990s. It is impossible to explore this period without taking into account the ways that it has been viewed by 'post-

Nationalist' critics. These critics-led by art historian Francis Pound-speak of the years between 1930 and 1970 as the 'Nationalist' period of New Zealand art and letters, when writers, artists and other cultural figures were engaged in the search for a national identity and a unique culture made of, by and for New Zealanders. As Wystan Curnow has observed, the use of the term 'Nationalist' (complete with capital ' $\mathrm{N}$ ') acts in the same way as the name of a political party or sports team, creating a sense of cohesion. ${ }^{2}$ The impression created is of a single-mindedness and lack of diversity which does not accurately reflect the rapidly changing thinking of the period, or the development from the selfconscious and deeply strategic calls for national schools of art and literature in the 1920s and 1930s to the questioning of the possibility of a single national identity in the 1950s and 1960s. For this reason, although I shall use the terms 'nationalist', 'nationalism' and 'nationalist period', I should like the reader to bear these concerns in mind, and recognise that part of my endeavour here is to show that a story different to that told by post-nationalist critics is also revealed by the records of the time.

It is also important to note at this point that Maria Brown's 1999 MA thesis, "The history and function of the Auckland City Art Gallery in constructing a canon of modernist New Zealand art', covers similar territory to this study. ${ }^{3}$ Brown's thesis is a painstaking piece of research that gives a broad picture of the Gallery's activities during the tenure of its first two professional Directors. In

\footnotetext{
${ }^{2}$ Wystan Curnow, 'Sewing up the space between', Midwest 7, 1995, p. 19. Hereafter abbreviated as Curnow, 'Sewing up the space between' (1995).

${ }^{3}$ Maria Brown, 'The history and function of the Auckland City Art Gallery in constructing a canon of modernist New Zealand art', unpublished MA thesis, University of Auckland, 1999. Hereafter abbreviated as Brown, 'The history and function of the Auckland City Art Gallery' (1999).
} 
order not to replicate Brown's work, I have chosen to focus on particular themes that are explored in detail by way of case studies. For the same reason, I have not attempted to list the exhibitions and acquisitions at the Gallery between 1953 and 1964, which are presented as extensive appendices to Brown's thesis.

Peter Alexander Tomory (born 3 January 1922) entered the field of arts administration at the beginning of the 1950s. During the Second World War Tomory had served in the Royal Navy, mostly in the Mediterranean. After demobilization, he studied at the University of Edinburgh (at the time one of only three institutions in Britain offering degrees in art history) where he completed a Masters in Fine Arts. As Brandon Taylor has noted, the move from service to study can be seen as characteristic of the post-war period, when a perception existed that education was 'both necessary and sufficient; that "a craving to live more through the mind and spirit" was a mark of enlightenment (perhaps of survival) in the hostile post-war world. ${ }^{\prime 4}$

After Edinburgh Tomory began his career in art administration, first as assistant curator at York Art Gallery, then, in 1951, as Keeper of the Leicester Art Gallery. From Leicester he moved to a position with the Arts Council of Great Britain, as an assistant regional director based in Birmingham. When the Council closed its regional offices, Tomory applied for the Auckland job. He was director of the Auckland City Art Gallery from March 1956 to December 1964, when he left to take up a senior lectureship in art history at the Auckland University

\footnotetext{
4 Brandon Taylor, Art for the nation: exhibitions and the London public 1747-2001, Manchester: Manchester University Press, 1999, p. 168. Hereafter abbreviated as Taylor, Art for the natıon (1999).
} 
School of Fine Arts. Tomory left New Zealand for New York and an appointment at Columbia University in 1968.

Tomory's tenure at the Auckland City Art Gallery coincided with a period of significant change in the visual arts in New Zealand-change which was in motion prior to his arrival, but also change which he personally effected in his various roles as a policy maker at the Gallery, as a writer on New Zealand art and art criticism, and as a lobbyist for greater professionalism in the arts sector. The second half of the 1940s had seen the establishment of a range of national cultural institutions, with the Labour Government's founding of the National Orchestra and the State Literary Fund (both in 1946) and the funding through the Department of Internal Affairs of scholarships for New Zealand actors, artists and musicians to study abroad. The Art Galleries and Museums Association of New Zealand (AGMANZ) was established in July 1947, with the objective of 'raising of standards of service, diffusion of knowledge and co-operation between institutions, of improving the qualifications and the remunerations for the personnel employed in these institutions. ${ }^{\prime 5}$

The 1940s also saw the movement of some artists away from the art societies and into other groupings, such as the Rutland Group in Auckland, which offered a more accepting environment in which to show modern art. Some artists, although not sympathetic to the art societies' policies, had joined nonetheless because membership granted an inexpensive means of exhibiting; these new groupings offered an alternative. ${ }^{\circ}$ Although venues other than the art societies existed-Progressive Books in Auckland and Modern Books in Dunedin, and the French Maid Coffee House in Wellington - it was not until the

\footnotetext{
${ }^{5}$ Gordon H Brown, New Zealand painting 1940-1960 conformity and dissension, Wellington: Queen Elizabeth II Arts Council of New Zealand, 1981, p. 33. Hereafter abbreviated as Brown. New Zealand painting 1940-1960(1981).

${ }^{6}$ Ibid., p. 21.
} 
very end of the decade and more particularly the 1950s that dealer galleries devoted to showing modern art would emerge, beginning with the opening of the Helen Hitchings Gallery in Wellington in 1949.

The 1950s saw other firsts: the appointment of the first professional director to a New Zealand public art gallery (Westbrook); the first exhibition consisting entirely of abstract works by New Zealand artists (Object and image at the Auckland City Art Gallery in 1954); groundbreaking exhibitions of international modern art (Henry Moore in 1956 and British abstract painters in 1958). The decade also saw New Zealand's artistic centre shift from Christchurch (the dominant city in the 1930s and 1940s) to Auckland. Gordon H. Brown has described the 1950 s as 'years of incredible pressure and discovery': 'the gradual ascendancy throughout the 1950s of Auckland as the leading centre for the visual arts', he observed, 'can be related to the rise of the Auckland City Art Gallery as the country's most progressive art gallery'.

A detailed discussion of the Gallery's innovative practices and its leading role in the arts in New Zealand at this time appears in a recent report on New Zealand's arts infrastructure. New vision: a critical view of New Zealand's visual arts infrastructure was commissioned by Creative New Zealand and The Chartwell Trust in 1997 to document changes in the arts infrastructure in the 1990s and to evaluate the role and functions of organisations within the arts sector. The report assessed how effectively these organisations developed, presented and promoted the visual arts. In a section dealing with public art galleries and museumsspecifically those which are locally funded but nationally significant - the authors used the achievements of the Auckland City Art Gallery between 1950 and 1970 as a 'model to remember' of the 'potential of such institutions to

\footnotetext{
? Ibıd., p. 89.
} 
contribute to the sustenance and development of the visual arts ${ }^{8}{ }^{\text {The }}$ Theport listed the establishment of the Auckland City Art Gallery Quarterly in 1956, the publication of a summary catalogue of works in the collection in 1964, the introduction of a series of shows of historical New Zealand art and an annual touring show of contemporary New Zealand art, and the creation of a representative collection of contemporary New Zealand art as major achievements at the Gallery in this period.

Contemporary reports show an awareness of the changing nature of the visual arts scene at this time. David Hall, in his 1955 book Portrait of New Zealand, described a 'quickening impulse' in the visual arts in the mid-1950s:

... an increasing boldness in experiment, and an increased self-confidence and disregard of the baser type of 'public opinion'. The public is probably better educated to appreciate art than at any previous time in our history, and public taste has sometimes recently been a step ahead of the cautious conservatism of art societies. ... Public patronage within its limits is increasingly discriminating. Auckland City has in recent years found the funds for the development of its art gallery on a scale which might well be imitated by other towns. Its first director, Eric Westbrook, set a high standard of taste and enterprise which has since been worthily maintained. ${ }^{9}$

Tomory himself remembers the period as one of struggle. In an interview with Anne Kirker in 1985, Tomory recalled that in the 1950 s the Gallery staff were trying to keep the institution 'intact': 'We were the only people doing anything at all ... the most important thing we did in the corporate sort of way was to in fact provide a public institution which supported the contemporary art movement.

\footnotetext{
${ }^{8}$ Michael Volkerling with Christina Barton and Jenny Harper for McDermott Miller Limited, New vision: $a$ critical view of New Zealand's visual arts infrastructure, Wellington: Creative New Zealand, 1998, p. 43 'Locally funded/nationally significant' galleries were defined as those which were principally funded by local government and were dedicated primarily to the presentation of contemporary art.

${ }^{9}$ David Hall, Portrait of New Zealand, [1955] Wellington: A.W. \& A.H. Reed, 1966, pp. 182-83.
} 
And that wasn't simply painting, but we supported poets, playwrights, music and so-on. ${ }^{10}$ In 1993, in an article for Landfall, Tomory again recalled the isolation of the Gallery at this time. Selecting the title 'The Bridgehead Revisited', he wrote:

My title may look like an imaginary Waugh, but it aptly describes the strategic situation of serious art in the second half of the Fifties in New Zealand. It might come as a surprise now to learn that the battle, anywhere, for contemporary twentieth-century art in those years was by no means won. ... My sharpest memories [are of] the conflicts that accompanied first the establishment of a bridgehead and then holding it. I had had some experience of this struggle in Britain, but there one had had the support of other institutions; in New Zealand the Auckland Gallery was on its own."1

This thesis examines how Tomory, as the Gallery's second professional director, went about establishing and maintaining this bridgehead. It records not only the conflicts but also the triumphs and the initiatives that are still regarded as important today, when professional museological practices are considered a given, and the days when boys from the local high school were co-opted to assist with hanging works and cleaning paintings are merely a distant memory. ${ }^{12}$

\footnotetext{
${ }^{10}$ Anne Kirker interview with Peter Tomory, 25 December 1985. Museum of New Zealand Te Papa Tongarewa Archives, MU466/12 [40] 1985/2 P. Tomory. Hereafter abbreviated as Kirker interview, Te Papa version, part 1.

${ }^{11}$ Peter Tomory, 'The Bridgehead revisited', Landfall, vol. 185, April 1993, p. 15.

12 This was the practice at the Suter Gallery in Nelson in the mid 1950s. Susan Butterworth, The Suter: one hundred years in Nelson, Nelson: Nikau Press, 1999, p. 83.
} 


\section{Peter Tomory and the Auckland City Art Gallery}

The new director seems a very good type. Quiet \& most efficient. I think it will be a good thing for the Gallery.

In the 1950s New Zealand's art galleries were almost entirely run by small, untrained staffs, working within tight budgets and administering impoverished purchase funds. The Auckland City Council was the first to employ an individual with a background in art administration to direct their art gallery. In 1948 Stuart Maclennan, a practising artist with no gallery training or experience, had been appointed as the first director of the National Art Gallery. Annette Pearse, after twelve years as honorary curator, was made the director of the Dunedin Public Art Gallery in 1957; likewise, in 1960 W.S. Baverstock was promoted from honorary curator to director at the Robert McDougall Art Gallery, Christchurch. In the mid-1950s, the staff at the Bishop Suter Art Gallery in Nelson consisted of the gallery's trustees and a part-time cleaner, and the gallery was often open without any attendants. The Sarjeant Gallery in Wanganui did not appoint a professional director until $1974 .^{2}$

Most public art galleries were closely associated with their local art society. The bulk of the McDougall's original collection, for example, was presented by the Canterbury Society of Arts; the Art Gallery Committee was comprised of four City Council members (who maintained financial control) and three Society members, who advised on 'artistic matters', including acquisitions. ${ }^{3}$ The National Art Gallery was bound to the New Zealand Academy of Fine Arts

\footnotetext{
${ }^{1}$ Colin McCahon, letter to Ron O'Reilly, 19 March 1956. private collection.

${ }^{2}$ To put this in context, however, regional galleries in Britain did not begin to appoint professional curators until the 1930s.

${ }^{3}$ Robert McDougall Art Gallery, The Canterbury Society of Arts 1880-1980. Christchurch: Robert McDougall Art Gallery, 1980, p. 16.
} 
(the Wellington art society), as the 1930 National Art Gallery and Dominion Museum Act included the provision for 'accommodation in perpetuity for the New Zealand Academy of Fine Arts, which had donated property, works of art and building funds to the National Gallery. ${ }^{4}$ Margaret Garland in 1951 suggested that this close relationship had hamstrung the development of the National Art Gallery's New Zealand collection, which betrayed a bias towards the type of traditional work favoured by art societies. ${ }^{5}$

The Dunedin Public Art Gallery also originated in an art society. The gallery's principal founder was painter William Mathew Hodgkins, who in 1875 established the Otago Arts Society, which began collecting works in 1881. In 1882 the Society approved Hodgkins' plan to begin a public collection of art works for the city. ${ }^{6}$ An entity to manage this collection, the Trustees of the Dunedin Public Art Gallery, was formed in 1890, incorporating new members who (unlike the art society members) were not involved in art in the practising sense. Peter Entwisle characterises the art society prior to the inclusion of these new members as a 'producer's co-operative', which favoured local artists rather than foreign masters; the new members however looked to Europe and Britain for guidance and acquisitions. ${ }^{7}$ Entwisle notes the differences between the Auckland and Dunedin galleries in the 1950s, attributing much of the support for contemporary New Zealand art in Auckland to Colin McCahon's presence at the Gallery. ${ }^{8}$ The Dunedin gallery under Pearse, he writes, was 'less concerned with advancing the claims of a new and unpalatable New Zealand art than with boldly developing a

\footnotetext{
${ }^{4}$ National Art Gallery of New Zealand, A guide book to the National Art Gallery of New Zealand, Wellington: National Art Gallery, 1969, p. 9.

${ }_{6}^{5}$ Margaret Garland, 'New Zealand painting in the National Gallery', Arts Yearbook 7, 1951, p. 131.

${ }^{6}$ Peter Entwisle, Treasures of the Dunedin Public Art Gallery, Dunedin: Dunedin Public Art Gallery, 1990. p. 11.

${ }^{3}$ Ibid., p. 13.

${ }^{8}$ Ibid., pp. 28-29.
} 
collection of acknowledged merit or one at least with the warranty of an overseas origin. ${ }^{\prime 9}$

Charles Brasch was a vocal advocate for the introduction of professional practices in New Zealand's public art galleries. In 1949 Brasch made a withering critique of the Dunedin Public Art Gallery's collection policy, especially its refusal to buy work by Frances Hodgkins. ${ }^{10}$ Brasch concluded that the poor state of New Zealand art galleries came down to the lack of professional direction, as the galleries' (largely amateur) trustee committees were ill-equipped to conceive and carry out acquisition policies. Five years later, in an article on the National Art Gallery, Brasch continued to call for professional directors to replace amateur committees:

\begin{abstract}
Wellington suffers from the same weakness as Dunedin: buying for an art gallery cannot be left to committees. To work out a policy and get it approved, and to buy in accord with that policy, is only possible for a professional director with full power. In the absence of such a policy, and of a director with power to carry it out, the Wellington and Dunedin galleries will never become collections: they will remain the incoherent miscellanies they are at present. ${ }^{11}$
\end{abstract}

Brasch ended on a hopeful note, declaring that 'the Auckland Gallery under Mr Westbrook promises to become a collection, the first in the country. ${ }^{\prime 2}$

During his tenure Westbrook did much to popularise and publicise the Gallery, significantly raising its profile locally and nationally by way of frequent speeches and radio talks and a wide-ranging exhibition programme that brought community groups into the Gallery. Gordon H. Brown has described Westbrook

\footnotetext{
${ }^{9}$ Ibid., p. 30.

${ }^{10}$ Charies Brasch. 'Art gallery policy', Landfall 11, vol. 3, no. 3, 1949, pp. 176-182. Hereafter abbreviated as Brasch, 'Art gallery policy' (1949).

"Charles Brasch, 'Round the galleries: Wellington', Landfall 30, vol. 8, no. 2, 1954, p. 128. Hereafter abbreviated as Brasch, 'Round the galleries' (1954).

?'Ibid.
} 
as a 'man of great charm', and in many ways an 'ideal first director', due to his ability to disarm prejudice and initiate projects which 'utilised a few enlightened individuals and thus made the task of revitalisation seem less daunting. ${ }^{\prime 13}$ Westbrook won financial as well as popular support for the Gallery, developed a clear collection policy and secured funding for acquisitions from the City Council. In a series of articles written for the Auckland Star at the end of his tenure, Westbrook called for more cooperation among New Zealand galleries and greater professionalism, observing that appointments to gallery posts had been to this point 'casual to the extreme', and arguing that staff should not just 'know about art', but also be trained in gallery procedures. ${ }^{14}$

Nevertheless, Brown sees Tomory's appointment as the true beginning of a professional approach to art gallery management in New Zealand. ${ }^{15}$ Tomory himself cast his predecessor as a trailblazer who had carved out a place for the Gallery in Auckland and in New Zealand, and cast himself as a consolidator, who would build upon this progress and ensure the continuation of the Gallery's pre-eminent position. An interesting insight into the differing styles of Auckland's first two professional directors can be found in Brown's 1979 interview with Colin McCahon. In the interview, McCahon recalls the 'last, greatest, most glorious' exhibition organised by Westbrook, the Engineers' Society exhibition:

McCahon: ... we had a train line all laid down properly on scoria, down the whole length of the big City Gallery, and the most astonishing telephone installations, for calling the cops and for doing anything you'd

\footnotetext{
${ }^{13}$ Gordon H. Brown, 'The visual arts' in Ian Wards (ed.), Thirteen facets: essays to celebrate the Silver Jubilee of Queen Elizabeth the Second 1952-1977, Wellington: Government Printer, 1978, p. 326. Hereafter abbreviated as Brown, 'The visual arts' (1978).

${ }^{14}$ Eric Westbrook, 'Public art collections should not be haphazard', Star, 1 December 1955, p. 4. Hereafter abbreviated as Westbrook. 'Public art collections should not be haphazard' (1955).

${ }^{15}$ Brown, New Zealand painting 1940-1960 (1981), p. 33.
} 
like - by the P \& T-and every conceivable thing. The floor had to be all done after this.

Brown: I can imagine with scoria.

McCahon: Ha, ha, ha, it was a ball. Tomory came in and asked; 'Is this an art gallery?'16

McCahon recalled Westbrook as 'absolutely the right person at the right time' to run the Gallery and raise its profile:

he wasn't really in the gallery all that often. He'd be off delivering ovations [sic] to Rotary and Lions and Women's clubs, all throughout the country. ... Yeah, he smothered New Zealand with 'culture'. A lot of it stuck. The Art Gallery Associates for instance came up out of this and of course, so did our theatre - which were done for the Associates. Oh a heap of things came up from it; including among other things the Associates' parties. ... the place was very much alive. Tomory was quite certainly the right person to succeed as Director and clamp down on sanity and organisation-and sort out who could show and who couldn't. ${ }^{17}$

Brown noted in the interview that Tomory gave the Gallery a professional status, but Westbrook had broken in both the Gallery and its public. McCahon agreed with him, and replied, 'If Westbrook hadn't have been there, and somebody like Tomory had come in, he would have cut his throat, he just couldn't have taken it. ${ }^{\prime 18}$

\footnotetext{
${ }^{16}$ Gordon H. Brown interview with Colin McCahon, 14 March 1979. Alexander Turnbull Library Manuscripts and Archives Collection, MS-Papers-2019, tape 3. p. 13. Hereafter abbreviated as Brown, interview with Colin McCahon (1979).

${ }_{17}^{17}$ Ibid., tape 3, pp. 13-14.

${ }^{18}$ Ibid., tape 3, p. 14.
} 
Between the announcement of Westbrook's resignation in June 1955 and the beginning of the search for a new director, a highly publicised attempt was made to establish a committee to advise the director on acquisitions and exhibitions. At a meeting of the Library and Art Gallery Committee in early August, Dr V.J. Chapman moved that a committee be formed to deal with 'all matters concerning the art gallery', which would meet prior to the Library and Art Gallery Committee meetings and make 'recommendations' to the Committee. ${ }^{19}$ The proposed committee would consist of the chairman of the Library and Art Gallery Committee, a member of the Library and Art Gallery Committee and nominees from the Elam School of Arts, the Auckland Society of Arts and the Auckland branch of the Institute of Architects. Chapman moved the proposal at the behest of a deputation made up of A.R.D. Fairburn (as a lecturer at Elam), A.J.C. Fisher (the Elam director), Vernon Brown (an architect and lecturer), and Pascoe Redwood (chairman of the Auckland Society of Arts). As reported by the New Zealand Herald, the deputation was interpreted as an attempted coup, and the motion framed as a threat to the autonomy of the director's position.

Westbrook opposed the establishment of an advisory committee, telling the New Zealand Herald that:

It is astonishing to me that, whereas for many years art interests in Auckland were not able to make any major achievements in connection with the gallery, now that the City Council has enabled the gallery to become a going concern all these people should now wish to advise the council on how to run it. ${ }^{20}$

Westbrook was also concerned over the selection of his successor. He believed that art gallery directors should be professionals, and that a committee could not make useful contributions to gallery policy: 'While artists and architects may be

\footnotetext{
19 'Move to control Art Gallery-Group's "dangerous" bid arouses anger', $N Z H, 9$ August 1955, p. 10.

20 'Mr Westbrook condemns Gallery control bid-Duty to public stressed', $N Z H, 10$ August 1955, p. 12.
} 
perfectly capable of choosing individual works or suggesting an idea for a single exhibition, the gallery director [must be] concerned in presenting over a long period of time a programme of exhibitions which will give the public ... an experience of the arts as full as possible, and one which they will thoroughly enjoy. ${ }^{21}$

The matter received considerable media coverage, indicating that the struggle for control of the Gallery was of public interest. Mayor Luxford described the New Zealand Herald's reporting of the meeting as 'mostly untrue and incorrect' and expressed his disappointment that 'discussion on the Art Gallery which took place in a committee meeting should have been divulged, and that the statements made about appointing a new director should be so misleading to the public. ${ }^{22}$ Richard O. Gross (chairman of the Mackelvie Trust Board) meanwhile congratulated the paper for exposing 'a definite move by outsiders to achieve a certain purpose all wrapped up to look nice. ${ }^{23}$ In a joint statement Redwood and Brown described the proposed changes as simply an extension of the current policy, which would allow the representation 'to be from groups rather than the appointment of individuals. ${ }^{24}$

Allen Curnow, in a letter published in the New Zealand Herald, compared the present argument to the earlier controversy in Christchurch over the purchase of Frances Hodgkins' The Pleasure Garden, noting that in that case 'the city council made a fool of itself on the advice of an art advisory committee composed of qualified persons. ${ }^{25}$ Curnow also questioned whether an art society and an art school were the best sources of objective advice. A director, in Curnow's estimation, should have the 'taste, knowledge, experience, personal

\footnotetext{
21 Ibid.

22 'Mayor's response', $N Z H, 11$ August 1955, p. 12.

23 'Mr Gross says Board is 'not too happy', NZH. 10 August 1955, p. 12.

24 'Art Society will put case to Mayor', Star, 10 August 1955, p. 3.

${ }^{25}$ Allen Curnow, "The Art Gallery controversy-A precedent to be avoided', NZH, 12 August 1955, p. 13.
} 
courage and integrity to keep the public gallery and its affairs above the level of local art factions and their devious, muddleheaded politics. ... A director who could not function in the best interests of the city without [supervision], would not be worth his salary.'26

Fairburn responded in a letter to the City Council stating that he saw the central issue as one of representation:

Should there be an 'art dictatorship'? Or should the City Council adopt a modified form of control, and knit the Gallery more closely into the cultural life of Auckland, by having an advisory committee of people to work with the director? ${ }^{27}$

Fairburn envisioned the committee working with the Director to advise the Library and Art Gallery Committee on purchases and exhibitions, thus protecting against any bias in taste that might arise from allowing one person complete control. Fairburn believed that merely employing an 'expert' would do little to ensure that the gallery reflected 'the life of a particular community, in time and place' as he believed it should. ${ }^{28}$

The debate came to little, however, as the Library and Art Gallery Committee announced on 26 August that a decision on an advisory committee would be deferred until after the arrival of the new director. In the event, the committee stayed much as it was until the issue was reignited in relation to the purchase of Barbara Hepworth's Torso II in 1963, when once again the autonomy of the Director's position was challenged. That such a debate occurred, however, and that it received considerable media attention, indicates that the shift from amateur or committee control of public galleries to management by

\footnotetext{
26 Ibid.

${ }^{27}$ Letter from A.R.D. Fairburn to the Auckland City Council, 14 August 1955. Alexander Tumbull Library Manuscripts and Archives Collection, MS-Papers-1128-099 p. 2.

${ }^{28}$ Ibid., p. 3.
} 
professionally trained individuals who were granted a significant measure of autonomy was not a simple process, but rather one where the concerns of groups who had a vested interest in the running of the institutions had to be negotiated.

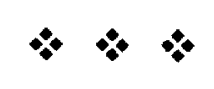

Tomory spent the three years prior to his Auckland appointment in Birmingham, as an assistant regional director of the Arts Council of Great Britain. In the late 1940s the Council began to reduce its activities outside London; by the mid 1950s the Council was heavily centralised and the regional offices were closed. In the interview with Kirker, Tomory noted that 'Britain in those days was so dismal', ${ }^{29}$ and that when the regional offices were closed, it was a question of 'what to do next, and the Auckland job came up. New Zealand sounded like a kind of Arcady. ${ }^{30}$

Established in 1945 and initially headed by renowned economist John Maynard Keynes, the Arts Council of Great Britain evolved from the Council for the Encouragement of Music and Arts, which during the Second World War had established a basis for government subsidy of the arts. ${ }^{31}$ The Arts Council, as the body through which the government subsidised the arts, was part of the same package that introduced the National Health Service, national insurance, nationalised industries and free orange juice. ${ }^{32}$ The new Arts Council was instrumental in the post-war introduction of contemporary art to mass audiences. Brandon Taylor describes the 'new mandarins' - a new generation of arts administrators and writers-as the link between the Arts Council and the

\footnotetext{
${ }^{29}$ Kirker interview, Te Papa version, tape 1.

${ }^{30}$ Anne Kirker, 'Peter Tomory's New Zealand years', Art New Zealand 40, Spring 1986, p. 71. Hereafter abbreviated as Kirker, Art New Zealand 40 (1986).

${ }^{31}$ Bryan Appleyard, The culture club: crisis in the arts, London: Faber and Faber, 1984, p. 24.
Ibid.
} 
battle for the acceptance of modern art in post-war Britain..$^{33}$ Figures such as Keynes, Herbert Read, Kenneth Clark, Phillip Hendy and John Rothenstein had academic rather than practising arts backgrounds and were influential in metropolitan circles and in Britain's national art institutions. They had progressive tastes and promoted international rather than just British art; most were 'ambivalent about radical politics and had their sights fixed upon the reform of the national artistic consciousness and the attitudes to modernism of its institutions. ${ }^{34}$

A 1946 report presented by the Arts Inquiry (the body through which the Arts Council was established) demonstrated the Council's aims and ideology. The intent of the report was, in Taylor's words:

[to] intensify and magnify the campaign that was already underway among the mandarins for the re-education of British taste. Modern art and its appreciation, the formulation and education of democratic and universal values, not only contributed to a vision which purported to connect nations rather than divide them, but on an individual level were to be related to the development of personality and the inculcation of standards of 'beauty' in a world still marred by ugly and dismal homes, streets and schools. ${ }^{35}$

The report, Taylor continues, did not have a 'populist' agenda, but rather 'ultimately [sought] to assist in the formation of a public of discriminating adults. ${ }^{36}$ A nationwide project of 'educating up' the population from childhood was suggested, drawing upon the ideas of Herbert Read, who in his 1943 Education through art argued that art education would result in better individuals and better communities. These beliefs are manifested in the memoirs of John

\footnotetext{
.3 Taylor, Art for the nation (1999), p. 170.

${ }^{34}$ Ibid.

35 Ibid., p. 174.

${ }^{36}$ The Visual Arts (The Arts Inquiry), Oxford: PEP Publications, 1946, p. 152, cited in ibid., p. 175.
} 
Rothenstein, an English museum professional at the forefront of the modernist curatorial revolution:

Among the ugly and disorderly cities of Britain Leeds was amongst the ugliest and most disorderly: surely the proper function of the Art Gallery was to be a place where the standards of beauty and order would be uncompromisingly upheld, a place from which beauty and order should radiate and permeate the minds of citizens and thus effect, even unconsciously, the way they felt about visual things, the way they made them, caused them to be made, the things they bought, and the city they lived in. ${ }^{37}$

Tomory described his role with the Arts Council as consisting partly of being 'evangelical' about art in the region, and partly of being an agent for the Council's exhibitions. ${ }^{38}$ Touring exhibitions were one of the Arts Council's key strategies for encouraging the arts in the provinces, and formed a major part of its work in the visual arts. ${ }^{39}$ The service was targeted at regional galleries who, aware of the shortcomings of their own collections, welcomed the opportunity to show subsidised travelling exhibitions. The exhibitions were of good quality, as was the interpretative material that accompanied them. The remarkable programme of touring exhibitions instituted at the Gallery during Tomory's tenure would suggest that he learnt much from his time with the British Arts Council.

In 1987 Tomory recalled his perception of the Auckland position at the time he took it up:

When I arrived in Auckland in March 1956, I was, as far as I was concerned at the time, about to start my third professional post in art

\footnotetext{
${ }^{37}$ John Rothenstein, Summer's lease: autobiography' 1901-1938, London: Hamish Hamilton, 1965, p. 196. Rothenstein was the director of the Leeds and Sheffield art galleries before heading the Tate Gallery.

38 'New gallery director has the right experience', Star, 8 March 1956, p. 4. Tomory also assembled a show, Subject and narrative, for the Arts Council, which examined the background of the Pre-Raphaelite movement. Kirker interview, Te Papa version, tape 1.

${ }^{39}$ Eric W. White, The Arts Council of Great Britain, London: Davis-Poynter, 1975, p. 177.
} 
museums; that what lay ahead would be similar to what I had been doing at York and Leicester in the U.K., building up the permanent collection, organizing a regular program of loan exhibitions and introducing professional systems for all the various operations, All these, of course, adapted to the particular characteristics and locality of the gallery concerned. ${ }^{40}$

Tomory's previous appointments, and the post-war spirit of modernisation and revitalisation among art galleries in England, appear to have influenced his actions in Auckland. For example, he recalled York Art Gallery before the Second World War as filled with 'rather bad pictures' on permanent display in the main gallery. ${ }^{41}$ After partial destruction in the war a store room was built, meaning works could be put away and drawn on selectively for exhibition. This was a practice Tomory went on to institute in Auckland. At York, under director Hans Hesse, Tomory's job was to catalogue the collection - another procedure he initiated in Auckland. Tomory recalled it as 'an excellent training ground', where he was occupied with 'learning the names and histories of bad painters, sorting out the good from the bad.' 42 In Leicester, Tomory had enjoyed a 'fine building', a gallery with a history of progressive directors, a staff of 20 and ample funding. ${ }^{43}$ These resources lent themselves to large exhibitions and scholarly catalogues; again, these are projects he undertook in Auckland.

Tomory's role with the British Arts Council also seems to have shaped his vision for the Gallery. Tomory's emphasis upon the role of the Gallery in educating the public about visual art and improving viewers' taste is aligned with the Arts Inquiry's intention to 'assist in the formation of a public of discriminating adults.' As Tony Green has noted, under Westbrook and Tomory

\footnotetext{
${ }^{40}$ Peter Tomory, draft of a short text for the 1988 history of the Auckland City Art Gallery, dated 11 May 1987, AAG Archives.

41 "New gallery director has the right experience", Star, 8 March 1956, p. 4.

42 Ibid.

${ }^{43}$ Betty Upton-Hughes, 'At home with Mr Tomory - The incoming man also has ideas', Star, 24 November 1955 , p. 4 . Hereafter abbreviated as Upton-Hughes, 'At home with Mr Tomory' (1955).
} 
the Auckland City Art Gallery was transformed 'from a Victorian mausoleum into a modern art museum. The model was British, the civic galleries of the new welfare state, which exposed contemporary art to the populace at large. ${ }^{\prime 4}$

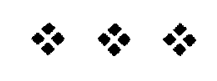

Tomory's appointment was announced on 11 November 1955. He came recommended by Sir Phillip Hendy (director of the National Gallery, London, who had headed the panel that selected Tomory from the four English applicants) with a 'sheaf of testimonials which could not be better in themselves or with regard to the positions of their writers', who included Rudolf Wittkower and Ernst Gombrich. ${ }^{45}$ Mary Dreaver, chairperson of the Library and Art Gallery Committee, told the Auckland Star that Tomory's 'scholastic training, his administrative, technical and lecturing experience made him the outstanding candidate' and that his testimonials 'paid tribute to his tact, personality and energy'. ${ }^{46}$

\section{Betty Upton-Hughes interviewed Tomory for the Auckland Star in} November $1955 .{ }^{47}$ The article gives an interesting insight into Tomory's plans for the Gallery, given that at this point he was forecasting into a situation he expected to be much like that which he was leaving. The article recounts that at

\footnotetext{
${ }^{44}$ Tony Green, 'Modernism and modernization', in Mary Barr (ed.), Headlands: thinking through New Zealand art, Sydney: Museum of Contemporary Art, 1992, p. 152. Hereafter abbreviated as Green, 'Modernism and modernization' (1992).

${ }^{45}$ Minutes of the Library and Art Gallery Committee, 9 November 1955, cited in Brown, The history and function of the Auckland City Art Gallery' (1999), p. 90.

46 The Committee debated whether Tomory should be appointed without a face to face interview; Mayor Luxford stated that he "want[ed] to see if he [Tomory] could operate under New Zealand conditions, under Auckland conditions - and we know there are some barbarous winds in the art world.' It was decided however that the Committee members were laymen. whereas Tomory had been judged by a group of his peers, and as all his referees had 'stressed his pleasing personality and tact' he would be appointed without an interview'. 'Auckland's director-to-be', Auckland Weekly' New's, 16 November 1955, p. 16.

${ }^{47}$ Upton-Hughes, 'At home with Mr Tomory' (1955). The following quotations in this section, unless otherwise noted, are drawn from this interview.
} 
Leicester Tomory arranged 'short courses of four lectures for housewives on the pictures in the gallery and how to look at them', and quotes him as saying that he was 'in favour of an art gallery being made a familiar place to everyone in the community'.

'Mr Tomory', wrote Upton-Hughes, 'is looking forward to the scope offered by the Auckland appointment. "One gets so tired of being weighed down by tradition here," he told me.' Tomory listed some of the initiatives he would like to see at the Gallery, including the establishment of a Friends of the Gallery organisation (in fact already established by Westbrook) and the lending of art works to schools. Tomory also indicated that he wanted to institute something like the York Art Gallery's quarterly publication to publicise new acquisitions and Gallery activities, and with luck bring the Gallery to the attention of expatriates who could then be encouraged to gift works to the collection. Significantly, Tomory added that he was 'keen on gallery publications' - during his tenure the Gallery would become New Zealand's leading publisher on the visual arts, and these publications would go on to play an important role in the construction of a New Zealand art history.

Upton-Hughes also noted that Tomory was enthusiastic about publicity and advertising, and in favour of New Zealand's four main galleries facilitating good touring exhibitions by sharing expenses. When questioned about an acquisition policy, Tomory replied that he would have to see what the Gallery's collection was like, but noted that through his work he was in frequent contact with London dealers, and that the Alfred East Art Gallery in Kettering, Northampshire, had made him their advisor on art purchases. Tomory listed his interests as the baroque, the romantic movement and the post-impressionists, particularly German expressionist painting, Gauguin and Van Gogh. UptonHughes noted that he 'criticized people-often art historians-who had no time 
for any art after the 18th century and who were uninterested in contemporary work.'

Tomory's emphasis upon professional standards was clearly communicated in the article. Upton-Hughes recorded that Tomory was 'particularly keen on an art gallery maintaining high standards-no matter what the size of the city', and quoted his opinion that:

It's no use putting local work in an art gallery alongside the masters unless the local art is as good as it possibly can be. It gives the layman the wrong impression. You can't have one standard for Kettering and another for the rest of the world. After all, there's only one standard for typewriters; why should there be more than one in art?

This statement foreshadows Tomory's repeatedly stated belief that the Gallery's primary role was to educate the public, not to nurture local artists. UptonHughes 'came away convinced that another director of lively ideas has been chosen to follow Mr Westbrook, and that Mr Tomory's experience in English provincial towns provides a good background for his task in Auckland.'

Tomory arrived in New Zealand on 5 March 1956. In an article titled 'New director wastes no time', the Auckland Star admiringly recounted that 'A man walked into the Auckland Art Gallery at 8.30 am today-a quarter of an hour before the staff arrived. The man? Mr Peter Tomory, of Birmingham, the gallery's new director, who only a few minutes before had stepped off the Wanganella, which had brought him from England. ${ }^{\prime 48}$ When asked by the media why he had applied for the position, Tomory replied that after studying art history, there was

\footnotetext{
48 'New director wastes no time', Star, 5 March 1956, p. 1.
} 
little choice. 'Mine is a very crowded profession in Britain', he was quoted in the Herald. 'Either you take a position with an art gallery or lecture on art at a university. These are the only two fields open.' ${ }^{49}$ Tomory stated that he had 'heard a great deal about the art gallery before he arrived', saying that while the gallery was not well-known in England, he had learnt a great deal from visiting Auckland tenor Andrew Gold, and also from Westbrook. ${ }^{50}$

Tomory gave a number of interviews at the time of his arrival, in which he expressed his vision for the Gallery. He declared that Auckland needed more small galleries for local artists to exhibit in, and to attract expatriate artists back to the country. He also made it clear that it was not the Gallery's duty to buy local artists' work: this was a practice, he stated, that normally resulted in such works going into 'cold storage; and that does the artist no good at all.'51 The job of the central gallery, he affirmed, was to 'educate the public rather than the artist. ${ }^{\prime 52}$ Tomory stated that his principal aim in Auckland was to raise the Gallery's professional standards, in order to stimulate the interest of both the public and artists. He felt that for this to be achieved there was an immediate need for the acquisition of an 'enormous number of good pictures. ${ }^{153}$ The situation in New Zealand was no worse than that in English provincial galleries, Tomory continued, with both having a 50-year gap in their collections that had to be addressed. His acquisition policy would be focused on consolidation, and primarily on adding to the groups of works that already existed in the collection.

\footnotetext{
49 'How new director views art galleries' $N Z H .6$ March 1956, p. 13.

50 'New director wastes no time', Star, 5 March 1956, p. 1.

51 'More smalt art galleries: new director's advice', NZH, 28 March 1956, p. 13.

${ }^{52}$ Ibid.

53 'Hothouse of art interest: aim of new director', NZH, 6 Aprll 1956, p. 13.
} 
Tomory was emphatic that it was not the Gallery's role to be the 'home of the living artist. ${ }^{54}$ Rather, he argued:

The gallery should be dedicated to the public, not so much to the artist. I met New Zealanders overseas, painters and others in the arts, and I am now principally concerned with trying to bring these people back. I feel that the only way to do this is to create a sort of hothouse of interest; that those people now overseas can come back assured of a certain amount of patronage and public interest - that the public will buy their pictures.

Now, I can't see that happening if the whole problem is left up to the Auckland Art Gallery to solve. We will buy young artists' work from time to time, but it is much better if we put our money into high, professional work so as to stimulate both the local artist and the public. ${ }^{55}$

Local painters, he felt, should be having their one-man shows in smaller galleries, yet to be established. Work by local artists should be shown only if it was of quality equal to that of the international work on display; anything else, Tomory felt, would 'tend more to cheapen the work of the local painter. ${ }^{\prime 56}$

These are the public records of Tomory's arrival. Other, more personal remembrances are also revealing. Peter Webb, a cleaner-attendant at the Gallery at the time of Tomory's arrival, recalled in 1993 the anxiety as staff awaited the 'ex Royal Navy Commander', fearing he would 'impose a more bureaucratic structure' on the Gallery. ${ }^{57}$ In the event, he recalled, 'Tomory the scholar' was the best possible successor to Westbrook. Fairburn, who disliked Westbrook's urbanity and sophistication, approved of the new director, noting in a letter to Denis Glover: 'The new Gallery Director here, Tomory, is an ex-naval type, and a first-rate bloke from every point of view. Thank heaven. After Pox-Pax. No

\footnotetext{
${ }^{54}$ Ibid. This comment seems somewhat ironic, given that McCahon not only worked at the Auckland City Art Gallery from 1953 to 1964, but also painted in the Gallery's attic.

${ }^{55}$ Ibid.

${ }_{57}^{56}$ Ibid.

${ }^{57}$ Peter Webb, 'Notes from a fifties diary', Landfall, vol. 185, April 1993, p. 19. Hereafter abbreviated as Webb, 'Notes from a fifties diary' (1995).
} 
more stroking or wanting to be stroked. No more whiffs of the east wind from Westfield.'58

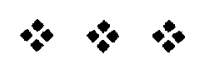

In early May 1956 Tomory presented his first report to the Parks and Library Committee, outlining his ideas for the future of the Gallery and setting the tone of his administration. His emphasis was that although the Gallery was now, in terms of its buildings, on a par with most provincial galleries in England and set to be 'one of the best equipped amongst the smaller galleries of the Commonwealth', fine buildings were of little relevance if the institution's professional standards and collections were not of an equally high quality. ${ }^{59}$

Tomory framed the Gallery as being 'poised at the crucial point of its career [when a] clear decision must be made as to whether it is to continue its career or to remain static, owning a collection of unimportant and mediocre works. ${ }^{60}$ During Westbrook's tenure the Gallery had been integrated into the life of the city by way of frequently changing exhibitions, lectures and concerts and also the attention drawn by the large-scale structural changes to the buildings. Westbrook's policy, in Tomory's words, had been to make the Gallery into a 'living cultural centre' by abolishing the existing 'museum atmosphere', largely by means of a programme of fast-changing temporary exhibitions. ${ }^{61}$ In this way, Westbrook had assumed the role of a reformer, 'instrumental in giving Auckland

\footnotetext{
${ }^{58}$ Lauris Edmond (ed.). The letters of A.R.D. Fairburn, Auckland: Oxford University Press, 1981, pp. 239-240. Hereafter abbreviated as Edmond, (ed.), The letters of A.R.D. Fairburn (1981). Fairburn puns here on the similarity between Westbrook's name and the name of an Auckland abattoir.

${ }^{59}$ Peter Tomory, 'Auckland City Art Gallery director's report April 1956', presented to the Parks and Library Committee 3 May 1956, p. 1, ACC Archives. Hereafter abbreviated as Tomory, 'Auckland City Art Gallery director's report April 1956'.

60 'Director says Art Gallery at crucial stage' NZH, 29 May' 1956, p. 12.

6) 'Sweeping changes at Gallery', Star, 31 May 1956, p. 4.
} 
what is physically one of the best small galleries in the Commonwealth, and to a large extent the cultural centre he foresaw' ${ }^{62}$

The Gallery's collection was Tomory's chief concern. His objective was to increase the value of the Gallery's collections so as to preserve the Gallery's lead over rival institutions. Feeling that the past five decades of unselective acquisition had left the Gallery with many 'worthless pictures' that disguised the better works in the collection, Tomory advised that more care be taken when accepting gifts and bequests, and that the Gallery focus on building up groups which already existed in the collection. He also urged that the Gallery begin collecting works which demonstrated the influence of Oceanic art on European art between 1880 and 1920, a collection which he believed would both be suitable given Auckland's place in the Pacific, and a distinguishing feature for the Gallery. Tomory also sought an increase in the acquisitions budget, which stood at $£ 1500$ per annum for the Gallery and approximately $£ 1000$ for the Mackelvie Trust. Before the Second World War this was an adequate sum, Tomory explained, but in the post-war art market works from particular schools had become increasingly rare, and prices in general had risen significantly. Without a larger budget the Gallery could not improve the quality of its collection, and this, in Tomory's opinion, was the most significant challenge faced by the Gallery.

Tomory, in the role of consolidator, outlined an exhibition policy that was pointedly different to Westbrook's. He acknowledged that the rapid turnover of exhibitions under Westbrook had been strategic while the Gallery had asserted its position in Auckland and in New Zealand. Tomory now urged a new approach, arguing that 'the holding of too many ephemeral exhibitions would turn the Gallery in time into a sideshow, and its proper function [will] become

${ }^{62}$ Ibid. 
obliterated. ${ }^{63}$ By reducing the number of exhibitions, a higher standard could be achieved, and staff would also have more time to concentrate on the collection. Tomory recommended that the Gallery should hold four or five exhibitions of oil paintings each year (sourced primarily from overseas) and a yearly exhibition of contemporary New Zealand painting, selected by Gallery staff. In Tomory's view, the temporary exhibitions should complement rather than outshine the display of the collection works.

In his proposed exhibition policy Tomory sought to limit the presence of local and amateur work in the Gallery. At York and Leicester Tomory had prevented the local art societies showing in the galleries, and he advised that in the interests of raising exhibition standards this should also happen in Auckland, with local art groups using the Lindauer room for their shows rather than the main body of the Gallery. As he vividly put it:

No-one would think of emptying the shelves of the Public Library of its better volumes and replacing them from time to time with amateur works by local writers. Neither should it have to happen in the Art Gallery. ${ }^{64}$

Again, Tomory cited professional standards. As a professional institution, he argued, the Gallery had to adopt professional practices. 'I fully understand from long experience,' he wrote, 'that the Gallery is looked upon by all local art societies as the proper place for their exhibitions, but this tradition took root in the days of non-professional curators and directors, and in England, where more and more galleries are being directed professionally, the practice of holding local art exhibitions has either come to an end, or some room apart from the main galleries has been set aside for the use of local art groups. ${ }^{\prime}{ }^{65}$

\footnotetext{
${ }_{64}^{63}$ Tomory, 'Auckland City Art Gallery director's report April 1956', p. 1.

${ }_{65}^{64}$ Ibid., p. 6.

${ }^{65}$ Ibid.
} 
Tomory's argument reflects his belief that the Gallery's core role was the 'raising and spreading of aesthetic standards amongst the public.' ${ }^{66}$ He wrote that the gallery was no longer the province of the amateur or the part-time connoisseur but the realm of the highly trained and specialised professional. The Gallery, he continued, had an 'international as well as a parochial service to perform', as only by adhering to international standards would it be capable of increasing interest in the visual arts in Auckland to long-term effect. ${ }^{67}$ Tomory's argument bears quoting in full:

Our main concern must be for the public and not for the artist, for true and lasting support for the artist must come from the patronage of the public and not from the Art Gallery. No cultured civilisation has yet owed its existence to an art gallery. This is not to deny the position of the Gallery in the cultural life of a city. It plays, or must play, the part of the preserver of standards and the authority in visual arts matters. Its collections and exhibitions must provide a comprehensive view of all periods of art which will interest and inform the public and stimulate the artist. In fact the heir to the well endowed private patron of the past is the art gallery. It must therefore be well informed so that its authority is unquestioned. It must be well-endowed with works for all to see. It must be host and mentor to public and artists of serious intent. It must be quick to quash the second rate and resist with all its might any attempt to undermine its prestige and weaken its authority. The Gallery must never become the unprotected king on the board of local art politics, nor the Hyde Park of every art orator. For the Gallery has a serious duty to perform and it must be allowed to perform this duty under the care of its professional staff and to follow a policy which will bring with it increasing respect and importance. ${ }^{\circ 6}$

The belief that the Gallery's primary role was the creation of an informed audience for the visual arts underpinned Tomory's approach to directing the Gallery.

\footnotetext{
${ }^{6}$ Ibid.

${ }^{67}$ Ibid., p. 1.

${ }^{\circ 8}$ Ibid., p. 1.
} 
Tomory's report was received with some scepticism in the press. While significant coverage was given to his proposals, some writers seemed dubious about the changes he proposed. A lengthy article in the Auckland Star, for example, summarised Tomory's recommendations in terse one-liners-'Scrap much of the existing collection', 'Drastically prune the number of exhibitions' while the final sentence grumbled 'How this enlargement of the policy of the last three years will appeal to Auckland's art public remains to be seen. ${ }^{69}$

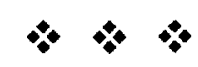

No gallery director ever acts alone, of course, and a consideration of the staffing of the Gallery under Tomory is not only important, but also interesting for what it reveals about what, for lack of a better term, might be described as Tomory's management style.

After the appointment of Westbrook, the next professional position established at the Gallery - in 1954 - was filled by Colin McCahon. McCahon moved to Auckland in May 1953, and began work at the Gallery in July, at first in a temporary role and then, from February 1954, as a permanent staff member with the title 'Display Officer'. In this role, McCahon organised exhibitions, wrote catalogue essays and looked after many of the practical aspects of the running of the Gallery. In addition, he tutored in the summer school art classes, and ran painting workshops and night-classes, activities that he continued in until he left the Gallery in September 1964.

Tony Green observes that McCahon's 'knowledge of art in New Zealand and his commitment to it made him an ideal ally for Westbrook and Tomory,

69 'Sweeping changes at Gallery', Star, 31 May 1956, p. 4. 
neither of whom had had previous experience of New Zealand art and

conditions. ${ }^{\prime 70}$ Peter Webb, who worked for both Directors, recalled in 1995:

While I believe that Westbrook and McCahon had a good deal of respect for each other-McCahon for what Westbrook was achieving by way of opening up the gallery to contemporary influences, and Westbrook for what he would recognize as McCahon's innate creative sensibility-I doubt if either could really bridge the gulf brought about by their totally different backgrounds. ${ }^{71}$

Webb has noted that McCahon was influential in decisions regarding the exhibition of local work, and particularly in reducing the number of exhibitions of art society work shown in the Gallery. ${ }^{72}$ McCahon expressed his own dislike of showing amateur work to Gordon H. Brown in 1979:

I don't like children's exhibitions in art galleries. I don't like strictly amateur people for exhibitions in art galleries, and I was very instrumental in having these chopped out.... When Westbrook was there it was all part of his policy-wang-you have a lot of them. Then you came to the point where you were getting people who had been to Summer Schools, going around yattering to their friends; I've got something hung in the Auckland Art Gallery. Well, okay, they had it hung, for one day at the end of the School. One gallery would be stripped down and they could all hang their own things, so everybody could see what they had done, ... it became distinctly too dangerous, ... they'd go home and there'd be terrific eruptions among the people who hadn't managed to get to the School, that hadn't had work hung in the Auckland City Art Gallery. And relations would come in years later, and say; 'Oh, my aunt's got a painting here. ${ }^{.73}$

McCahon served as acting director in the months between Westbrook's departure at the end of 1955 and Tomory's arrival in March 1956. During this

\footnotetext{
${ }^{70}$ Tony Green, 'McCahon's visit to the United States: a reading of letters and lecture notes', Bulletin of New Zealand Art History, vol. 3, 1975, p. 19. Hereafter abbreviated as Green, 'McCahon's visit to the United States' (1975).

${ }^{71}$ Webb, 'Notes from a fifties diary' (1995), p. 18.

${ }_{72}^{72}$ Peter Webb, personal communication to the author, 10 February 2004.

${ }^{73}$ Brown, interview with Colin McCahon (1979), tape 3, p. 9.
} 


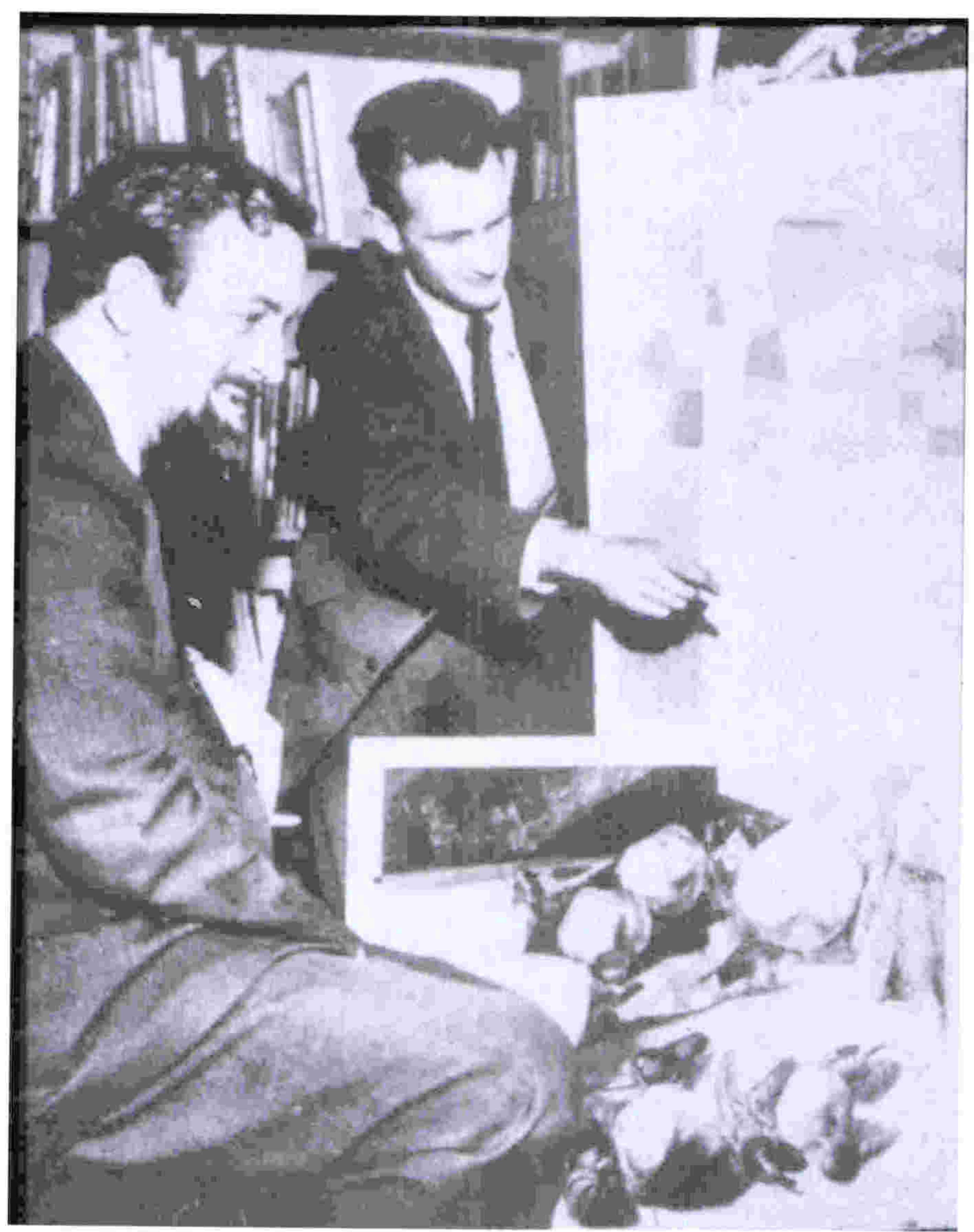

Peter Tomory (left) and Colin McCahon (right) at the Auckland City Art Gallery, c. 1957 
time he attempted - unsuccessfully - to bring 'Works by Paul Klee from the collection of Mrs Hulton', a recent Tate exhibition, out to Auckland. More successful was McCahon's development of a relationship during this time between the Gallery and the San Francisco Museum of Art, through the Museum's director, Dr Grace McCann Morley, when she visited Auckland. Beginning with a publication exchange programme, this relationship grew when Morley assisted in negotiating a travel grant for McCahon's 1958 trip to the United States from the Carnegie Corporation. The Museum also worked with the Gallery on the 1961 exhibition Painting from the Pacific.

Webb suggests that McCahon developed a closer relationship with Tomory than his predecessor, noting that 'Tomory and McCahon had an immediate rapport, strengthened by the former's willingness to socialize with staff at the end of the working day. ${ }^{174} \mathrm{He}$ also recalls that Tomory and McCahon worked together on the planning of exhibitions and the selection of local artists, with Tomory drawing on McCahon's knowledge while he familarised himself with the New Zealand scene. ${ }^{75}$ Gordon H. Brown suggests that later in his tenure Tomory took more control over the showing of New Zealand artists (although continuing to discuss artists and their work with McCahon), especially in the annual touring survey shows, as he recognised the ethical dilemma that McCahon was placed in by including his own work in the Gallery's exhibitions. ${ }^{76}$ However, this precaution may not have been sufficient. As Hamish Keith recalls, McCahon played a significant role in developing Tomory's tastes in New Zealand art, which may have been to the detriment of certain artists. ${ }^{77}$ Certainly

\footnotetext{
${ }^{74}$ Webb, 'Notes from a fifties diary' (1995), p. 19. Webb appended to this statement the note that 'only $\mathrm{McCahon}$ and myself regularly stayed back for a drink.'

${ }_{75}^{75}$ Peter Webb, personal communication to the author, 10 February 2004.

${ }^{76}$ Gordon H. Brown, personal communication to the author, 19 January 2004.

${ }^{77}$ Hamish Keith, personal communication to the author, 9 February 2004.
} 
Eric Lee-Johnson (whose work found more favour with Westbrook than with Tomory) felt this to be the case, writing in his autobiography that:

Tomory ... was more for imported '-isms' and keeping up with the Northern Hemisphere Joneses. He appeared also to be influenced by South Islander Colin McCahon, now on the gallery staff ... The media have always regarded the Auckland City Art Gallery as the oracle in questions of aesthetics, and Colin's powerful hand and narrow view in judging which New Zealand painters should be encouraged could be seen in all directions. Painters not approved by McCahon and Tomory ceased to be invited to submit paintings for major exhibitions, and several left the country in disgust. Colin, with his genius affirmed by writers like Gordon Brown and Hamish Keith, had taken courage to use his gallery position to highlight his own work, having no compunction about giving his paintings the most commanding place in every show. ${ }^{78}$

McCahon's involvement at the Gallery was not only with New Zealand art and artists; his role required him to care for and document all works in the collection. Tomory in 1985 recalled that McCahon knew every old master work in the Gallery 'by heart', and noted that he had learnt much from McCahon, because he had an 'extraordinary objective attitude towards painting. ${ }^{\prime 79}$ That McCahon was familiar with and interested in the international works (both historical and contemporary) is evident in his contributions to the Gallery's Quarterly, where he wrote on a range of artists, from French modernist painter Armand Guillaumian to the contemporary American artist Karl Kasten (one of whose paintings McCahon gifted to the Gallery).

\footnotetext{
${ }^{78}$ Eric Lee-Johnson, Eric Lee-Johnson: no road to follow, Auckland: Godwit Press, 1994, p. 155. It should be noted at this point that Tomory's more lengthy discussions of McCahon's work appeared in texts written after both had left the Gallery (for example, in Painting 1890-1950 and Ascent). Likewise, Keith did not write extensively on McCahon's work while McCahon was at the Gallery, and Brown, although friends with McCahon, did not work at the Gallery at the same time as the painter.

79 Anne Kirker interview with Peter Tomory, 25 December 1985. Museum of New Zealand Te Papa Tongarewa Archives, MU466/12 [41] 1985/2 P. Tomory. Hereafter abbreviated as Kirker interview, Te Papa version, part 2.
} 
Tomory described the staffing at the Gallery as 'a mess' at the time of his arrival, and recalled that he spent the first year rearranging the staffing for a better pay structure. ${ }^{80}$ In his first report to the Auckland City Council, Tomory suggested that staff titles should be altered to conform to European nomenclature, and to reflect the special nature of the duties and the authority attached to the title. McCahon was renamed 'Keeper', with his job description now officially including the practical running of the Gallery and the direction of the professional staff. Tomory renamed Peter Webb and John Henderson 'Student Assistants', rather than 'attendants'. Prompted by the lack of professional staff to recruit in New Zealand, Tomory introduced a new emphasis on training; he hoped that Webb and Henderson would be able, through a combination of on-the-job training and tertiary study, to equip themselves for professional posts in any public gallery. ${ }^{81}$ Tomory envisaged that the Gallery would earn a reputation for the professional training of gallery staff, noting in his first report to the City Council that the importance of this work in maintaining professional standards cannot be overstressed.. ${ }^{82}$ Later in 1956 a professional conservator, C.L. Lloyd, was taken on, an appointment that reflects the emphasis Tomory placed on caring for and documenting the collection. Also on staff were two attendants, two administration assistants (including the longserving Brenda Gamble), a typist and a forecourt technician. Tomory noted in the 1985 interview that this was a larger staff than an institution of Auckland's size would normally have..$^{83}$

In the context of this study, the positions of most interest are those of the Keeper and the two student assistants. In $1957 \mathrm{Webb}$ and Henderson both left the

\footnotetext{
${ }^{80}$ Kirker interview, Te Papa version, part 1.

${ }^{81}$ Green, 'McCahon's visit to the United States' (1975), p. 19.

${ }^{82}$ Tomory, 'Auckland City Art Gallery director's report April 1956'. p. 2.

${ }^{83}$ Kirker interview, Te Papa version, part 2.
} 
Gallery (Webb to found the Peter Webb Gallery, the first dealer gallery in Auckland to specialise in contemporary New Zealand art), and were replaced by Hamish Keith and Ross Fraser. McCahon's role as Keeper (or what now would be called 'curator') included caring for the collection and documenting its use. One part of this role was the creation of a card index system to record the works in the collection. Gordon H. Brown suggests that McCahon would have worked under Tomory's guidance here, as he would have been unfamiliar with cataloguing procedures. Brown suggests that McCahon, personally interested in these topics, would have been a 'quick learner as well as a patient researcher. ${ }^{84}$ Keith and Fraser worked as McCahon's assistants. Hamish Keith, recalling a typical day at the Gallery, said:

We would arrive at the Gallery at nine-ish ... and till ten o'clock we'd help the cleaners clean, and that included Colin as well. At ten o'clock we would have a cup of tea, which really involved long, contested conversations between Ross, Colin, I and Peter, about every subject art historical or otherwise that you could think of, and out of that came a lot of our exhibitions or purchases or whatever. And once that moment had finished we went back to our work which generally speaking was almost everything. We would hang works, we would catalogue works, we would write about works. ... In those days that meant doing everything, you didn't pass things on to another department, ... we did virtually everything; we would select works, write about them, write the biography, research the works, frame the works and hang them on the wall. And then in our lunchtimes we went out to the front desk. ${ }^{85}$

In addition, Tomory, McCahon, Fraser and Keith answered public enquiries, gave lectures and floortalks, and Keith joined McCahon in his teaching activities. Tomory also set Keith and Fraser to work on the British Museums Association's programme in arts administration, reflecting his insistence upon professional training. This insistence is also apparent in his support for McCahon's trip to the

\footnotetext{
${ }^{84}$ Gordon H. Brown, personal communication to the author, 19 January 2004.

${ }^{85}$ Hamish Keith, personal communication to the author, 9 February 2004.
} 
United States in 1958. Although much study and guess work has been devoted to the artistic influences McCahon may have absorbed during his three months in America, the primary purpose of the trip was to study administration and education programmes ('administration, and uninteresting subjects like that', he told Brown in 197986) in North American art galleries and museums. In a letter to the Auckland City Council, Tomory wrote:

I would like to point out that this is not merely a pleasure visit, for $\mathrm{Mr}$ McCahon will be working alongside art gallery staffs in some of the greatest museums in America and thus his professional knowledge will be substantially increased by this tour. This is the first occasion that I know of [that] any professional member of a New Zealand gallery has visited America. The Auckland Art Gallery already holds a fairly high reputation overseas for its purchases and re-building programme. $\mathrm{Mr}$ McCahon will also be giving lectures on New Zealand painting both old and new, and I feel that Auckland can only gain from this visit. In Europe, a tour of this kind would be considered fundamental training for professional art gallery personnel ... ${ }^{87}$

Hamish Keith recalls that although he and Ross Fraser were in training for the first three years of their time at the Gallery (after which they were given the title 'Assistant Keeper') there was 'no sense in any way that we were treated like children.'88 In 1958 - the year of his appointment-Keith was given his first exhibition to manage, a show of the work of the colonial New Zealand artist John Kinder, complete with a biographical catalogue. Tomory called upon outside knowledge for this series of exhibitions on historical New Zealand artists - Una Platts, for example, curated J.C. Hoyte (1957) and Colonial Auckland (1959), and Eric McCormick worked with the Frances Hodgkins collection-but also

\footnotetext{
${ }^{86}$ Brown, interview with Colin McCahon (1979), tape 3. p. 9.

${ }^{87}$ Peter Tomory, letter to the Auckland Town Clerk, cited in Green, 'McCahon's visit to the United States' (1975), p. 20. Gordon H. Brown attributes part of the close relationship that McCahon and Tomory developed to Tomory's support of McCahon in this instance. Gordon H. Brown, personal communication to the author, 19 January 2004.

${ }^{88}$ Hamish Keith, personal communication to the author, 9 February 2004.
} 
encouraged his staff in this work. McCahon, therefore, was responsible for J.C. Richmond (1957), A colonial view (1958), The paintings and drawings of Frances Hodgkins (1959), Six New Zealand expatriates (1962), and James Nairn and Edward Fristrom (1964), while Keith also produced James Preston (1959) and Early watercolours of New Zealand (1963)..$^{89}$

Ross Fraser in 1993 recalled that the Gallery had a 'liberal atmosphere of great creativity and idealism' in the 1950s, especially in terms of its ambition to foster the arts in Auckland. ${ }^{90}$ Fraser was given significant responsibility in the fulfilment of one of Tomory's long-term goals at the Gallery, the publication in 1964 of $A$ summary catalogue of paintings, drawings and sculpture. Gordon H. Brown sees the achievement of this goal as evidence of Tomory's skill in getting the staff at the Gallery - from McCahon to Brenda Gamble - to work together on a single project. There is also Tomory's introduction of the Auckland City Art Gallery Quarterly in 1956, a publication aimed firstly at the Art Gallery Associates but also intended to drum up more attention and support for the Gallery from the wider public. The Quarterly - which profiled events at the Gallery and featured short articles on recent acquisitions and works in the collection - was an endeavour which required input from all members of the professional staff. Brown sees the production of the Quarterly (an eight-page, well-illustrated publication which would have required substantial research as well as typographical skill) as another example of Tomory's ability, through the rapport that he built with his staff, to bring his staff together on a project and simultaneously increase their skills and professional abilities.

\footnotetext{
${ }^{89}$ I am grateful to Gordon H. Brown for providing me with this list.

${ }^{90}$ Ross Fraser, 'Looking back: memories of painting in Auckland through the 1950s', Art New Zealand 66 , Autumn 1993, p. 57. Hereafter abbreviated as Fraser, 'Looking back' (1993).
} 
Hamish Keith describes Tomory as a 'very inspiring and inspired director'. ${ }^{91}$ In addition to his emphasis upon professional practice, Keith remembers Tomory as being 'very, very insistent and thorough about teaching your eye ... we really were encouraged to look and read and consider.' He recalled, when asked how he looked back at this period of his life:

I think it was very formative and very enlarging in the sense that I was changed from the narrow kind of xenophobic views of Christchurch through contact with a larger and more spacious sort of culture. And intellectually it was very, very satisfying. Peter was a very fine man to cross swords with. We were encouraged to think. We weren't encouraged to have theories, but we were encouraged to think, we were encouraged to puzzle, for example, why Albrecht Durer's woodcuts of the Tarot, the so-called Tarrochi, weren't of Tarot at all. Those were the sort of questions we'd find in a magazine and start to talk to Peter about, and say well, how did this happen? And then you'd trace some other object which came from Clutha. ... It was a very stimulating time..$^{92}$

\footnotetext{
${ }_{92}^{91}$ Hamish Keith, personal communication to the author, 9 February 2004.

${ }^{92}$ Ibid.
} 


\section{The permanent collection}

In the gallery we are not interested in parlour trivia, past or present, but in creating for the first time in this country a seriously planned collection of European and New Zealand painting and sculpture which will stimulate, give pleasure and educate not only the present but also future generations of New Zealanders. ${ }^{1}$

The Auckland City Art Gallery's collection has its origins in the late-nineteenthcentury gifts of Sir George Grey and James Tannock Mackelvie. Grey, governor of New Zealand from 1845 to 1853 and 1861 to 1867 , was the founding donor of both the Gallery and Auckland's public library, gifting 53 paintings and a collection of books and manuscripts in 1887. Mackelvie, a Scottish businessman, lived in Auckland between 1865 and 1871 and made a sizeable fortune in the Thames goldfields. After returning to London, Mackelvie began collecting in a wide range of fields - from painting to porcelain - and from 1876 sent regular consignments of artworks to Auckland. Mackelvie died in 1885; he bequeathed his entire collection to four Auckland trustees and the Mackelvie Trust fund was established, which continues to acquire works that are housed and displayed at the Gallery.

The Gallery cannot be said to have had an acquisition policy until it came under Westbrook's direction, when annual funding for acquisitions was secured from the Auckland City Council. Before this, donations formed the bulk of the Gallery's collection - most notably, the donation of the Partridge collection of Maori portraits by Gottfried Lindauer in 1915, Lucy Carrington Wertheim's gift

\footnotetext{
1 Peter Tomory, 'The Art Gallery moves to its goal', undated and unattributed article in the Auckland Art Gallery scrapbook, c. late 1958, probably from the Star. Hereafter abbreviated as Tomory, 'The Art Gallery moves to its goal' (1958).
} 
of work by modern British artists in 1948, and regular presentations of works by the Auckland Society of Arts.

Westbrook had on his arrival described New Zealand's public art collections as a 'sorry lot of stuff', and observed a 'deep distrust of the New Zealand artist, particularly those who have never traveled abroad ... Apparently there is a superstition here, too, that real art ended about 1900. ${ }^{2}$ Westbrook argued that gallery directors should be given greater autonomy in building collections, and stated in an article in the Auckland Star that he could see the 'virtue in pruning the cumbersome buying procedure' which required the director to pass information before 'sub-committees, committees and councils' before a decision could be made to purchase a work. ${ }^{3}$ Westbrook noted that while acquisition committees acted as safeguards they also hampered the speed at which decisions could be made and - combined with New Zealand's distance from the major art markets - this led to galleries missing out on desirable works. Using Auckland as an example of the benefits of placing 'more trust' in directors, Westbrook described an occasion where he was able to secure Frances Hodgkins' Spanish Shrine (1933) from 'under the noses of American rivals. ${ }^{4}$ Westbrook was not simply concerned with streamlining the acquisitions process. He also believed that acquisition committees often made decisions (admittedly unintentional) that detrimentally affected collections. 'Buying by committees', he wrote, 'is a dreary business, and frequently the paintings acquired are precisely those which will offend no one and equally delight no one. ${ }^{5}$ Given the authority to act independently, Westbrook continued, a director could secure works for the collection more effectively, and the collection would in turn benefit from 'the

\footnotetext{
${ }^{2}$ Brown, New Zealand painting 1940-1960 (1981).p. 33.

'Eric Westbrook, 'Public art collections should not be haphazard' (1955).

${ }^{4}$ Ibid.

${ }^{5}$ Ibid.
} 
character and liveliness which would come from an individual informed judgment."6

As noted, Charles Brasch had also identified the need for professional gallery directors - 'men trained for their work, by experience in properly run galleries (which means overseas ones) and as students of the history of art' - who would be responsible for framing policies and making decisions on purchases. ${ }^{7}$ Brasch noted in 1954 that under Westbrook's direction the Gallery was fast leaving the other centres' public art collections behind. The Auckland City Council was the first to create a public gallery that achieved the three things Brasch had called for: the employment of a professional director, the reduction of committee control over purchases, and the development of a clear collection policy. It was also the first to provide funding for acquisitions, and although the director had to pass proposed acquisitions before a purchases advisory committee and then the Council, he was given considerable freedom to follow the policies he instituted. First Westbrook and then Tomory formulated collection policies aimed, despite their different emphases, at building a representative collection that would make the Gallery a useful public resource and educational institution.

Westbrook's collection policy was developed to accommodate limited financial resources. In 1953 he advised that the Gallery:

- Concentrate first on the work of New Zealand artists. Noting that other galleries and libraries had good collections of early New Zealand work, Westbrook suggested Auckland should concentrate on contemporary art,

\footnotetext{
Ibid

'Brasch, 'Art gallery policy' (1949), p. 182.
} 
which would encourage younger artists and optimise the limited funds to build a representative collection for the future.

- Build a representative Frances Hodgkins collection.

- Create a representative collection of 19th- and 20th-century prints as an educational tool for students and the public. These prints were to stand in for the paintings from these periods that the Gallery could not afford to purchase.

- Buy 20th-century British painting and sculpture.

- Aim for a collection of representative works from all periods. This, in Westbrook's opinion, did not necessarily mean collecting the best artists, but obtaining a wide range of artworks that could be used to demonstrate artistic movements and themes.

- Collect New Zealand craftwork. ${ }^{8}$

Westbrook's and Tomory's acquisition policies differ in Tomory's emphasis on collecting good-quality international painting from all periods. Where Westbrook had seen this as financially difficult and was ready to compromise, Tomory insisted that the Gallery had to be able to present the full breadth of Western art history. In 1989, in the introduction to their catalogue of pre-1800 European paintings in Australasian collections, Tomory and co-editor Robert Gaston debunked the notion that 'the only good old master is one that costs six figures' as a 19th-century attitude. ${ }^{9}$ Tomory insisted that through wise buying and knowledge of the market, representative (if not prominent) works could still be acquired for the old master collection. Where Westbrook placed New Zealand art as his first concern, Tomory accorded it a secondary role, and

\footnotetext{
${ }^{8}$ Eric Westbrook, An exhibition of acquisitions 1952-1953, Auckland: Auckland City Art Gallery, 1953.

${ }^{9}$ Peter Tomory and Robert Gaston, European paintings before 1800 in Australian and New Zealand public collections: summary catalogue, Sydney: Beagle Press, 1989, p. 8.
} 
made no mention of purchasing applied art. Tomory's emphasis was on consolidation, and in terms of the permanent collection this meant a radical reconsideration of the way the collection was used in the Gallery, and swift action to reinvigorate a collection that had been allowed (in his opinion) to languish for five decades.

In his first report to the City Council, Tomory had emphasised the importance of developing the Gallery's collection, telling the Council that a gallery's reputation rested largely on the quality of its permanent collection. He noted that the Gallery's international collection included some good old master works, five Italian works, some Dutch pieces, some English paintings and some small pieces of modern sculpture bought by Westbrook, forming a bedrock he considered to be worth developing. ${ }^{10}$ Tomory advised that the Gallery should focus on building up existing groups in the collection, selecting the following for immediate attention: 19th-century English and French paintings, drawings and prints; old master drawings and prints of the 16th, 17th and 18th centuries; 20thcentury English and European painting; 19th- and 20th-century sculpture. ${ }^{11}$ Tomory's discussion of the acquisition of New Zealand art was less detailed; in 1985, Tomory recalled that the New Zealand collection was 'a lot more difficult' to approach. ${ }^{12}$ In 1956 he considered the Hodgkins collection to be almost complete, and summarised his plans for the remainder of the New Zealand

\footnotetext{
i" Kirker interview, Te Papa version, tape 1.

"In his personal correspondence, Tomory was less optimistic about the quality of the collection. In a letter to Ellis Waterhouse in 1956, he wrote: "we have a collection of what the book-sellers label "Curious". Every picture that we have appears to have been cut down, or cut out.' Peter Tomory, letter to E.K. Waterhouse, 23 April 1956, AAG archives. In another letter to Waterhouse, Tomory noted: 'We have several other things here which I hope to get photographed soon, but you never saw such an extraordinary collection of chopped up and chopped down pictures.' Peter Tomory, letter to E.K. Waterhouse, 29 August 1956, AAG archives. One of the main obstacles to cataloguing the collection was the lack of reference books: in the letter of 23 April, Tomory wryly observed 'There are, as you suspected, no books in New Zealand at all, but I have hopes of at least getting together enough to allow us to catalogue our own collection.'

${ }^{12}$ Kirker, Art New Zealand 40 (1986), p. 73.
} 
collection in two sentences: 'Paintings from all periods of New Zealand painting should be acquired when suitable and first class works appear. Good examples by certain of the earlier painters should be sought out and acquired.' ${ }^{13}$ The prioritising of the collection of international works is consistent with Tomory's oft-stated opinion that the Gallery, rather than directly supporting the local artist, should educate and stimulate the public, thus creating an informed audience which would independently begin to support living New Zealand artists. It also indicates an apparent diffidence on Tomory's behalf - at least initially - towards New Zealand art. In 1985 Tomory recalled putting off buying contemporary New Zealand art for two years, stating that he wanted to familiarise himself with art practice throughout the country. ${ }^{14}$ Hamish Keith notes that although Tomory did much for the advancement of New Zealand art (especially by way of his touring shows, as will be discussed in the following chapter) he seemed somewhat uncomfortable with New Zealand art to begin with. ${ }^{15}$ In a recent letter published in Art New Zealand Keith stated that while McCahon and Tomory should be credited for the active interest the Gallery took in contemporary New Zealand art during this time, a considerable number of the contemporary New Zealand works shown in the collection displays were in fact on loan from artists, and that from 1965 onwards (when Keith served as Acting Director) the belated business of purchasing them for the collection was undertaken. ${ }^{16}$

\footnotetext{
13 Tomory, 'Auckland City Art Gallery director's report April 1956', p. 4.

${ }^{14}$ Kirker, Art New Zealand 40 (1986), pp. 72-73.

${ }^{15}$ Hamish Keith, personal communication to the author, 9 February 2004.

${ }^{10}$ Hamish Keith, Letter to the Editor, Art New Zealand 101, Summer 2001-2002, p. 92. The loan scheme was initiated in 1957, when the Gallery began borrowing works from contemporary New Zealand artists. including Toss Woollaston, Doris Lusk, Russell Clark. Milan Mrkusich and Dennis Knight Turner, which were hung in the Gallery with plans for future purchase (see Auckland Citv Art Gallerv Quarterly, no. 5, 1957. p. 7). Hanish Keith recalls that from 1965 he undertook the process of either formally acquiring these works for the collection, or returning them to the artists (Hamish Keith, personal communication to the author, 9 February 2004). An interesting implication of the belated purchase of works is that some of the New Zealand works in the Auckland Art Gallery collection catalogued as entering the collection in the late 1960s may have already been on display in the Gallery for a considerable period of tıme. This makes it
} 
Under Tomory the Gallery's acquisition policy was modelled on practices at modern international art institutions. In an article summarising the first two and a half years of his tenure, Tomory emphasised the modern direction taken at the gallery, noting that 50 years earlier galleries like Auckland had served as convenient shelters 'for as many pictures as can be crammed on the walls, regardless of quality or period' ${ }^{17}$ Now, he declared, Auckland had caught up with international practices; the idea of what an art gallery should be had 'permeated into the provinces from the great art galleries in Paris, Berlin, Rome, London and New York'. ${ }^{18}$ As a result most galleries (including the Auckland Gallery under his direction) by the mid 20th century 'adhere[d] to a general policy of presenting to the public works of art of as high quality as funds permit, and at the same time acquiring these works so that certain periods and schools of art are presented as fully as possible. ${ }^{\prime 19}$

Tomory explained that the Gallery's policy was akin to that of similarsized galleries overseas; rather than specialising in a particular period of art, Auckland directed its acquisitions policy towards building up current holdings. He noted that in order to create a 'more unified' collection the Gallery had purchased 20th-century European paintings and original prints. This idea of a 'unified' collection was very important to Tomory, and he placed much emphasis upon the need to understand the collection as a whole when discussing the collection with his staff. ${ }^{20}$ Regarding New Zealand works, Tomory simply noted

difficult to reach firm conclusions about trends in the acquisition of contemporary New Zealand art during Tomory's tenure simply by analysing acquisition records.

${ }^{17}$ Tomory, 'The Art Gallery moves to its goal' (1958).

${ }^{18}$ Ibid.

19 Ibid.

${ }^{20}$ Hamish Keith, personal communication to the author, 9 February 2004. Ross Fraser observed in 1993 that a 'spirit of democracy prevailed [at the Gallery]. Tomory would ask the advice of all of us in making his choice of, particularly, modern work for the collection.' Fraser, 'Looking back' (1993), p. 57. Keith also recalls Tomory's openness toward his staff's suggestions: 'we didn't have formal meetings, or internal purchasing committees or planning. ... We just went to Peter and said "this this and this" and he'd say 
in this article that this aspect of the collection had not been neglected, with purchases made to fill gaps in earlier decades and the acquisition of contemporary work. ${ }^{21}$

Tomory also noted the benefits of the professional attention that the collection had received over the past two and a half years. Researching the international collection - particularly the holdings of earlier European workswas one of Tomory's first and most important actions at the Gallery. In this way, two works previously attributed to Ruisdael and Hobbema had been exposed as poor-quality copies, while more positively the St Sebastian in the Mackelvie collection had been firmly attributed to Guido Reni. The previous years, Tomory wrote, had seen an 'agonising reappraisal' of the collection, but now the Gallery was creating a well-planned collection, of both New Zealand and European work, which would 'stimulate, give pleasure and educate not only the present but also future generations of New Zealand. ${ }^{22}$

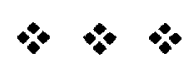

Tomory developed strategies to deal with Auckland's distance from the international art markets, especially the London market which he was accustomed to dealing in. Buying works on the international market had the

\footnotetext{
"yes, do it" or "no, we can't" for that reason or this reason. ' Hamish Keith, personal communication to the author, 9 February 2004.

${ }^{21}$ Between 1956 and 1958, acquisition records show that the Gallery purchased nine contemporary works, by Stewart Maclennan, Rita Angus, Kase Jackson, Colin McCahon, Michael Nicholson, T.A. McCormack, Anne May Smith, Wilfred S. Wallis and M.T. Woollaston. Gifts of contemporary works by Angus, Gabrielle Hope, Lincoln Lee, McCahon, McCormack and Olivia Spencer Bower were also accepted. It should be noted that by the end of this period. the loan scheme for contemporary New Zealand work had been initiated. In the same period. 31 works by earlier New Zealand or New Zealand-based artists were purchased, including works by Frances Hodgkıns, Louis J. Steele, Henry J. Warre, Alan B. Warwick, Grace Joel, Girolamo Nerli, Horatio G. Robley, Alfred Walsh, J.C. Hoyte and Petrus van der Velden; works by Hoyte, Steele, van der Velden, Hodgkins. Vyvyan Hunt and Gottfried Lindauer, among others, were accepted as gifts. See Appendix 6 and Appendix 7 in Brown. 'The history and function of the Auckland City Art Gallery' (1999), for full details.

${ }^{22}$ Tomory, 'The Art Gallery moves to its goal' (1958).
} 
extra fillip of attracting international attention to the Gallery - works bought in the London market, for instance, were often reported in the London papers. Tomory maintained contact with a number of dealers in London, who offered the Gallery first right of refusal. During Tomory's tenure the Gallery did not have a representative in London and instead dealt directly with vendors, informing dealers of the Gallery's needs and using, in Tomory's words, 'photographs and experience' to select works. To keep informed the Gallery received catalogues and price lists from Christies and Sothebys by airmail (with two weeks advance notice of each sale), and subscribed to the Times to keep tabs on exhibitions. ${ }^{23}$ There was also Tomory's network of art historians who could be called upon to check attributions. The Auckland Art Gallery's archives hold a considerable amount of correspondence between Tomory and Ellis Waterhouse (a historian of baroque and English art and at this time the Director of the Barber Institute of Fine Arts in Birmingham) and also between Tomory and Ulrich Middeldorf, a historian of Italian renaissance sculpture and Director of the Kunsthistoriches Institut in Florence, who originally contacted Tomory regarding the Institut's project to catalogue Italian works held in overseas collections. ${ }^{24}$ Middeldorf in turn would occasionally refer tricky works sent to him by Tomory on to the Italian expert Roberto Longhi for attribution.

Potential acquisitions sometimes surfaced when private owners sent works to the Gallery's conservation service for cleaning or restoration. Works were also

\footnotetext{
${ }^{23}$ Peter Tomory, letter to E.K. Waterhouse, 23 April 1956, AAG archives. Tomory notes in this letter that advance notice "will allow us at least to choose what we wanted to buy, rather than having pictures thrust at us by enterprising dealers.' In this letter Tomory also wrote: 'There is a fair amount of money, one way and another, for purchases of pictures and I would be most grateful should you hear of anything worthwhle coming from a country house, or such like, if you would let me know.'

24 The collection of correspondence between Tomory and Waterhouse in the Auckland Art Gallery archives is particularly fascinating. Shortly after his arrival Tomory began to have works from the collection photographed, and would send these photographs to Waterhouse; their letters are robust pieces of connoisseurship, with the two art historians (and friends) battling over attributions based on the photographs of works that they would exchange.
} 
discovered as Tomory travelled around the country scouring public and private collections to put together exhibitions such as Old master paintings from the private and public collections of New Zealand (1959) and Modern European paintings in New Zealand (1960). ${ }^{25}$ It was part of the Gallery's policy to buy old master works from private collections to keep them in New Zealand, but Tomory was quite clear that while he paid fair prices, they were not London prices, and if the owners wanted these they could go to the trouble of shipping them overseas themselves. ${ }^{26}$ Tomory's discovery in 1963 of a cache of drawings by the AngloSwiss artist Henry Fuseli is still one of the most important finds in New Zealand art history, and Tomory himself regarded this as the 'peak discovery' of his tenure. ${ }^{27}$ As Ross Fraser tells the story:

Tomory had gone to a Dunedin house to look at some paintings when, as they were drinking some tea, his hosts told him rather diffidently about some drawings they had that might be worth looking at. He persuaded them to show him the portfolio, which turned out to contain thirty-seven Fuselis, in perfect condition and from most periods of the artist's oeuvre. ${ }^{28}$

For Tomory, the find was 'one of those things that turns up once in an art historian's lifetime. ${ }^{29}$ In 1979 he described the collection as 'astonishing for its chronological representation and the high quality of most of the drawings', which cover all but two periods of the artist's oeuvre and most of his major subject areas. ${ }^{30}$ Tomory successfully negotiated the Gallery's purchase of the drawings for $£ 1500$. Catalogued by Tomory, the collection formed the basis of

\footnotetext{
${ }^{25}$ Kirker interview, Te Papa version, tape 1. The practice of borrowing works from private collections for exhibitions reveals another way in which the Gallery enabled artworks to circulate around a wider audience, in addition to the touring shows that were generated in this period.

${ }^{26}$ Kirker interview, Te Papa version, tape 1.

${ }^{27}$ Ibid.

${ }^{28}$ Ross Fraser, 'The gallery's first eighty years', Quarterly of the Auckland City' Art Gallerv, no. 49, March 1971, p. 19. Herafter abbreviated as Fraser, 'The gallery's first eighty years' (1971).

29 'Cup of tea leads to art coup of a lifetime', NZH, 27 February 1965, section 3, p. 5.

${ }^{30}$ Peter Tomory, The poetical circle: Fuseli and the British. Florence: Centro Di and Australian Gallery Directors' Council, 1979, p. 15.
} 
the Gallery's 1967 exhibition A collection of drawings by Henry Fuseli RA, and was also shown in London in 1968 in an exhibition at London dealer gallery Roland Browse and Delbanco. ${ }^{31}$ Presumably it was this experience that gave Tomory the impetus to write his book, The life and art of Henry Fuseli, published in $1972 .{ }^{32}$ In 1975 the collection formed the framework for The poetical circle: Fuseli and the British, an exhibition selected by Tomory and sponsored by the Australian Gallery Directors' Council, which toured Australia and New Zealand.

The Auckland Gallery Associates played a significant role in the development of the collection, and donated nearly half of the contemporary New Zealand works gifted to the Gallery during Tomory's tenure, including Christopher Perkins's Frozen Flames (1931), Colin McCahon's Here I give thanks to Mondrian (1961) and Patrick Hanly's Figures in Light 17 (1964). The Rutland Group donated McCahon's Takaka: Night and Day (1948) in 1959, and a group of McCahon's students donated his Yellow and Black Landscape (1962) in 1962. Artists also gifted works to the Gallery; Angus donated a watercolour, Lupin (c. 1953), in 1960, Woollaston gifted two portraits in 1961 and McCahon gifted a number of works by artists including Woollaston, Hanly and American artist Karl Kasten. In all, gifts of contemporary New Zealand work accounted for nearly half of the acquisitions in this area during Tomory's tenure. That these works were gifted, however, does not exclude them from being seen in relation to the collection policy, as Gallery staff members were heavily involved in the selection of donations. Maria Brown suggests that donation-especially of McCahon's work, given his employment at the Gallery and his lack of popular support-allowed Gallery staff to avoid presenting works to the Parks and Library Committee for

\footnotetext{
${ }_{31}^{31}$ Fraser, 'The gallery's first eighty years' (1971), p. 19.

${ }^{32}$ Peter Tomory, The life and art of Henry Fuseli, London: Thames and Hudson, 1972, translated into German in 1974 by Peter Hahlbrock.
} 
approval. As Tomory remarked to Kirker:

That was the point when the committee could be a nuisance. They weren't against contemporary art as such but they had rather firm views; they wouldn't have looked at someone like Mrkusich for instance.

They tended to favour Eric Lee-Johnson and anyone who painted cabbage trees. At the Gallery we called such artists the 'colonial house and cabbage tree school'. Anything else struck them as being somewhat radical. $^{33}$

Bequests and benefactors also played an important role. Tomory encouraged members of the public to view themselves as benefactors, and saw the Gallery's Quarterly as a vehicle for encouraging patronage. In 1960 Tomory described acts by benefactors as the two 'most noteworthy events' at the Gallery that year-the donation, respectively, of paintings by Pietro Faccini and Paris Bordone by J. Yock and N.B. Spencer. ${ }^{34}$ Tomory explained that these donations were important for two reasons: the works came from private collections (showing a certain depth in New Zealand's private collections) and also represented serious private patronage.

As a gallery with a small acquisitions budget (in international terms, if not local ones), Auckland had to be canny with its funds. In 1960 Tomory noted that the Gallery was attempting to expand its collections during a boom in the art market, with works from popular periods having doubled in price in the previous decade. By acquiring works from periods not currently in favour, Tomory explained, the Gallery could make the most of its limited funds. Tomory stressed the difference between the public art gallery and the private collector; the private collector buys for personal pleasure, the public institution buys 'not only to give pleasure but to inform and to raise standards of appreciation. ${ }^{35} \mathrm{~A}$

\footnotetext{
${ }^{33}$ Kirker, Art New Zealand 40 (1986), p. 73.

${ }^{1.4}$ Peter Tomory, 'A gallery's reputation is built on that of its collections', Star, 20 September 1960, p. 20.

is Ibid.
} 
public institution also has an obligation to future audiences, and hence, to Tomory's mind, the importance of buying 'serious art' from the 20th century.

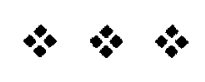

Tomory's acquisition of German expressionist works for the Gallery demonstrates an interesting continuity in collecting practice between his time in England and his time in New Zealand. Tomory had travelled in Germany before the war, and in early interviews noted that German expressionism held considerable interest for him. As Keeper at Leicester, Tomory purchased three German expressionist works for the collection: Max Pechstein's Coast Scene with Boats (1909) and two lithographs by Max Ernst, Etoile de Mer and Masques. The German expressionist collection at Leicester originated in 1944 with the acquisition of four paintings from the collection of Alfred Hess, but while these major acquisitions were considered to be of significant interest by subsequent Keepers, Tomory was the first to extend the collection. ${ }^{36} \mathrm{He}$ also staged two exhibitions of expressionist work during his tenure at Leicester, one from a private collection and one of graphic work and stone carvings by Karl SchmidtRotluff. The works for the latter exhibition came from the collections of SchmidtRotluff and the art historian and major Die Brücke patron Rosa Schapire, who had come to England as a refugee from Germany at the beginning of the Second World War. Tomory corresponded with Schapire, and she visited Leicester to give a lecture. Schapire wrote to a friend in 1953:

My lecture, to a rather small but very select audience, met with no response. Leicester ... is a philistine place. All the more pleasing, therefore, that the Director, Mr Tomory, who is very interested in German Expressionism, buys German pictures, the only provincial museum in

${ }^{36}$ Julia Collieu, personal communication to the author, 3 December 2003. 
England to do so, despite a more than modest budget. We got on brilliantly and parted real friends. ${ }^{37}$

Schapire subsequently bequeathed 24 works on paper by Schmidt-Rotluff to Leicester in 1955. The acquisition of these works in the 1940s and 1950s was seen as unusual, and the Leicester collection of German art is now internationally renowned and seen to reflect the institution's progressive collecting policies since the early 1940 s. $^{38}$

While Tomory did not buy any German expressionist paintings for Auckland, he added a number of 20th-century German prints to the collection. These include works by George Grosz, Käthe Kollwitz, Lyonel Feininger, Lovis Corinth and Erich Heckel. Rosa Schapire had obviously developed a real respect for Tomory, as she bequeathed seven woodcuts by Karl Schmidt-Rotluff to the Gallery. ${ }^{39}$ While these works are notable for their links to Tomory's earlier position, the print collection as a whole reflects trends in collecting practices not evident in the higher-profile collections of painting and sculpture. As Tomory noted in an issue of the Quarterly:

In the last five years or so the Gallery has been acquiring graphic work with a very definite policy in mind. The desideratum of a balanced collection necessitates, in our case, filling gaps in schools and periods with prints or drawings by important artists: this we have tried to do. ${ }^{40}$

Contemporary international prints were a regular feature in the exhibition programme, given the ease with which they could be transported. The

\footnotetext{
${ }^{37}$ Rosa Schapire, letter to Agnes Holthusen, 19 September 1953. Cited in Shulamith Behr, 'Dr Rosa Schapire-art historian and critic in exile' in 'Keine Klage über England?' Proceedings of the Second International Symposium on German and Austrian Exile Research in Great Britain 1933-45, C. Brinson, R. Dove, A. Grenville, M. Malet and J. Taylor (eds.), Institute of Germanic Studies and Judicium Verlag, London and Munich, vol. 72, 1998, p. 219. My thanks to Julia Collieu for sending me this article and the accompanying translation.

${ }^{38} \mathrm{http}$ //nationalmuseums.org.uk/spoliation/lists_non/leicester.html. Accessed 4 December 2003.

${ }^{39}$ Auckland City Art Gallery Quarterly, no. 1, 1956, p. 6.

${ }^{40}$ Auckland City Art Gallery Quarterly', no. 23, 1962, p. 2.
} 


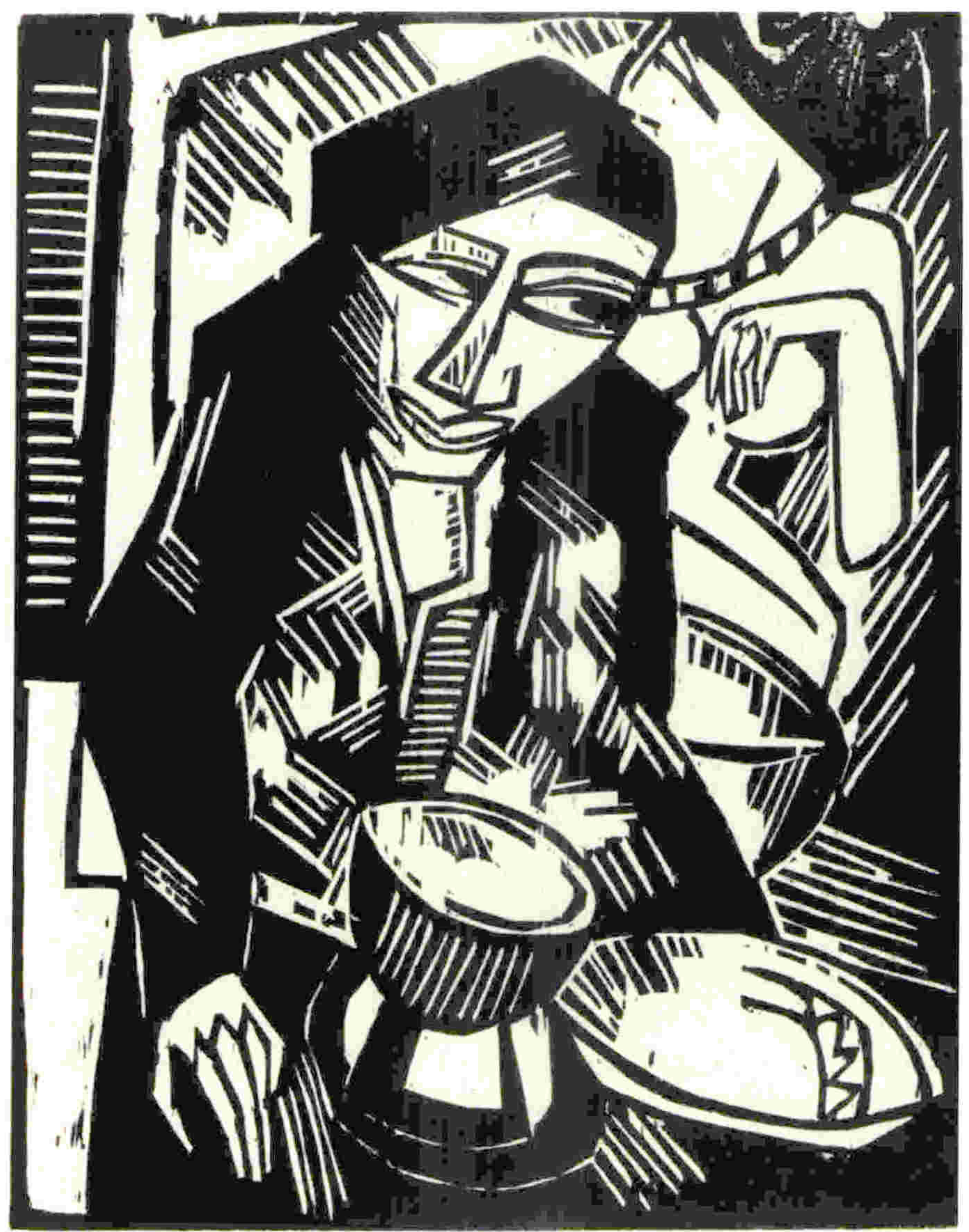

Karl Schmidt-Rottluff, Melancholy, 1914, woodcut, $500 \times 900$ mm, collection of the Auckland Art Gallery Toi o Tāmaki. This work is one of seven woodcuts by the German expressionist artist gifted to the Gallery by Rosa Schapire in 1956. 
acquisition of prints for the collection reflects to some extent the exhibitions that were held; the acquisition of works by Rouault from the 1957 exhibition is a good example. Unusually for the period-sufficiently unusual for Tomory to make a special mention of the fact in the Quarterly - the Gallery held a group of modern Japanese prints of the sosaku hanga school, the only such collection in a public gallery in New Zealand at this time. ${ }^{41}$

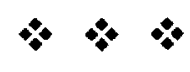

As Carol Duncan has written, an art gallery's 'sequenced spaces and arrangements of objects, its lighting and architectural details provide both the stage-set and the script' for the visitor's experience. ${ }^{42}$ In this way, Duncan continues, museums offer carefully laid-out stories, 'most often in the form of art-historical narratives that unfold through a sequence of spaces. ${ }^{43}$ Duncan uses the Museum of Modern Art, New York (MoMA) as an example of how the exhibition of works in art galleries is predicated upon the art-historical discourse that the institution supports; in this case, the evolution of modern art towards two forms of formal expression, labelled by MoMA director Alfred Barr 'nongeometrical abstract art' and 'geometrical abstract art'. As Christoph Grunenberg has observed:

In the MOMA's spaces visitors had to progress through a series of galleries without the danger of digression. In the labyrinth of MOMA's galleries, the visitor is subjected to a compulsory course in recent art history following the development of modern art in a clear logical sequence'.4

\footnotetext{
4 Ibid.

42 Carol Duncan, 'The art museum as ritual' in Civilising rituals: inside public art museums, London and New York: Routledge. 1995, p. 12.

${ }^{43}$ Ibid., p. 13.

${ }^{44}$ Christoph Grunenberg, 'The politics of presentation: the Museum of Modern Art, New York', in Marcia Pointon (ed.), Art apart: art institutions and ideology across England and North America, Manchester and
} 
In a similar manner, Tomory intended that visitors should receive a certain impression of the collection; namely, that visitors to the Gallery should view New Zealand art as part of a wider art-historical tradition. He envisioned the Gallery's permanent collection as 'the first in New Zealand where European art from the sixteenth to the twentieth centuries and New Zealand art is presented as a unity. ${ }^{\prime 45}$ The permanent collection was hung in such a way that visitors encountered first New Zealand painting, then pre-1850 European work, then European painting and sculpture of the 20th century. Works were hung chronologically, divided by media and country of origin. This followed the typical practice in Britain, which had developed in the mid-19th century. British institutions at this time were strongly influenced by the developing discipline of art history, especially in Germany; this was also the period when the precursors of provincial art museums, the large-scale exhibitions such as the Manchester Art Treasures Exhibition of 1857, were staged. The idea grew during this time that the national collection 'should be organised on historical lines, illustrating not only the progress of art but the rise and decline of the individual schools and the mutual influences of schools and artists. ${ }^{46}$ As Giles Waterfield has noted, the German emphasis upon national schools of painting necessitated that the

\footnotetext{
New York: Manchester University Press, 1994, p. 203. Grunenberg here cites H.A. Read, 'Art in our time', The American Magazine of Art, no. 32, 1939, p. 339.

${ }^{45}$ Tomory, Connoisseur (1959), p. 10.

${ }^{46}$ This display practice - still largely followed in most art museums - became widespread in the 19th century. As Giles Waterfield explains, in the last third of the 18th century a discourse developed among international connoisseurs around the theme of the importance of national considerations in the cataloguing and display of works of art-a discourse that owed much to the thinking of the German art historian Winckelmann who (unlike his predecessors, who concentrated on the lives and works of great masters) regarded 'the purpose of art history as the study not of the lives of individual artists, but of the origins, rise to perfection and decline of schools, and the examination of the different styles produced by various peoples as a result of the meteorological climate to which they were exposed, their political constitution and ways of thought, their attitudes to artists and the uses to which the arts were put in their society.' Giles Waterfield, 'The origins of the early picture gallery catalogue in Europe, and its manifestation in Victorian Britain', in Susan Pearce (ed.), Art in museums, London and Atlantic Heights, NJ: The Athlone Press, 1995, pp. $62-63$.
} 
development of a British school had to be illustrated within the national collection. ${ }^{47}$ Provincial art museums began to be established in Britain in the late 19th century; their collections (like Auckland's) tended to be based upon gifts and bequests, or acquired from annual exhibitions, and they were established with the aim of 'contributing to general education and entertainment rather than of appealing to a specialized audience. ${ }^{48}$ This historical context forms the background for Tomory's experience at Leicester and York, and undoubtedly influenced his practices in Auckland.

Tomory believed it was the Gallery's task to bring the two halves of the collection-New Zealand and European works - together. In an article in the Connoisseur he stated that the Gallery faced the task of 'relating New Zealand's own creative arts, which may not yet have obtained an international significance but have their local importance, to the European works. ${ }^{\prime 49}$ It was Tomory's ambition to create 'a gallery where the New Zealander may see all these things together. ${ }^{50} \mathrm{He}$ was adamant, however, that in achieving this goal the Gallery could not afford to lower its standards, and notably it was not until 1958 that he observed that the gallery visitor could now move from the New Zealand to the European works 'without feeling there is a sudden drop in impact or quality on entering or leaving any one of these rooms. ${ }^{.51}$

A significant effort was made to modernise and enhance the Gallery's infrastructure. During 1956 the Mackelvie gallery was given a new roof, ceiling and wall coverings, while at the same time many works in the collection were cleaned and re-framed (or placed in storage, as in the case of a number of 'large

\footnotetext{
${ }^{47}$ Ibid., p. 66.

${ }^{48}$ Ibid., pp. 66-67.

${ }^{49}$ Tomory, Connoisseur (1959), p. 10.

${ }^{50}$ Peter Tomory, 'The Art Gallery moves to its goal' (1958).

${ }^{51}$ Ibid.
} 


\section{AUCKLAND CITY ART GALLERY}

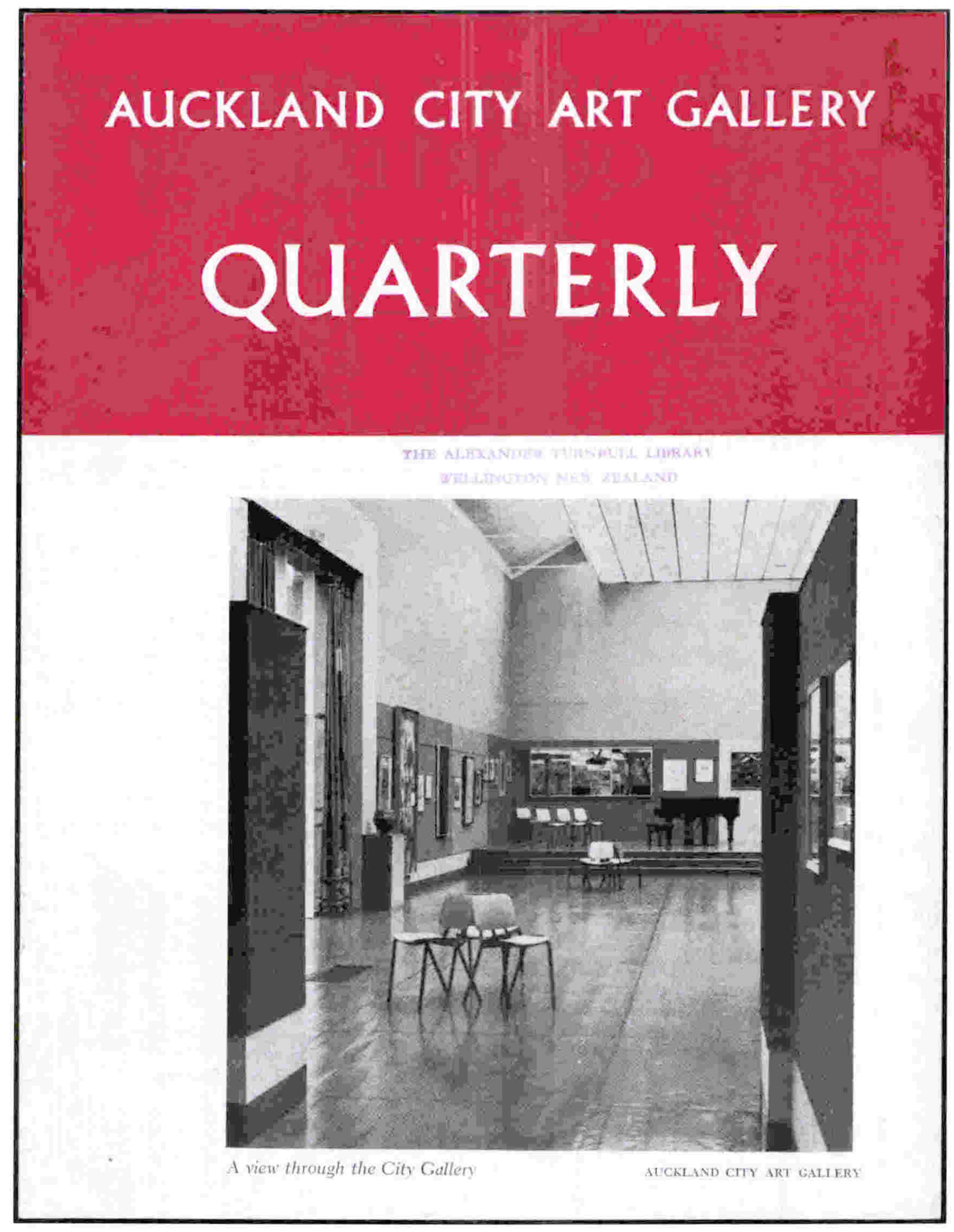

Cover of the Auckland City Art Gallery Quarterly, no. 14, 1960, showing an installation view of New Zealand art on display on the Gallery. Colin McCahon's 1952 painting On building bridges, acquired for the Gallery in 1958, can be seen on the far wall. 
and indifferent' works from the Mackelvie collection). ${ }^{52}$ The revamped gallery opened in November with an exhibition of 80 works, many from the Mackelvie collection, the result of Tomory's suggestion to the Auckland City Council that the Mackelvie collection and the City collection (which had previously been shown separately) be integrated. ${ }^{53}$ Tomory told the Auckland Star that 'many people would get a surprise' when they saw the hang, as this was the 'first careful selection of the cream of the Mackelvie and City collections that has yet been made'.$^{54}$

Several years later Tomory caused a local controversy when, as part of his overhaul of the display of the permanent collection, he placed the majority of the Gallery's collection of C.F. Goldie's and Gottfried Lindauer's Maori portraits in storage. Tomory, as Roger Blackley succinctly put it, performed the role of the 'modernist cat amongst the colonial pigeons' with his criticism of Goldie and Lindauer. ${ }^{55}$ In late 1954, under Westbrook's direction, fifty works by Goldie and Lindauer, re-clad in thin white frames, were placed on display in a 'dowdy' room. By 1960 this room had been emptied to make way for the Auckland Gallery Associates' clubroom. Of the 62 Lindauer portraits in the Partridge collection, seven were hung in the vestibule, while several of Goldie's paintings were hung in a nearby staircase. This demotion did not pass unremarked by gallery visitors, and provoked angry letters to the editors of Auckland's newspapers deploring the poor treatment of the paintings; a suggestion from

\footnotetext{
52 'Agreement will integrate Gallery's pictures', Star, 2 June 1956, p. 3.

${ }^{53}$ Ibid. Westbrook had attempted to renegotiate this arrangement, instituted with the establishment of the Mackelvie Trust, but the Mackelvie trustees retained the use of certain wall space until this point.

${ }^{54}$ Mac Vincent, 'The Aucklander's Diary', Star, 20 November 1956, p. 4. Again, Tomory's correspondence with Waterhouse reveals a more measured assessment of the re-hang: 'We are almost nearing the end of our re-building programme and have at last got most of the permanent collection up on the walls; a somewhat sorry lot they look too, but we have some nice things amongst all the doubtful starters and we hope in a year of two to have weeded them out.' Peter Tomory, letter to E.K. Waterhouse, 4 December 1956, AAG archives.

${ }^{55}$ Roger Blackley, Goldie, Auckland: Auckland Art Gallery Toi o Tāmaki and David Bateman, 1997, p. 37.
} 
Lee-Johnson that the works might be better housed at the Auckland Museum was rejected by one writer on the basis that such a move would make the Gallery 'an even drearier place than it is now. ${ }^{56}$

Under the inflammatory headline 'Lindauers inferior says Mr Tomory', an Auckland Star reporter recorded Tomory's response to visiting Australian artist Rubery Bennett's opinion that Lindauer's Maori portraits should be displayed more prominently in the Gallery:

It is an absurd idea to take down two excellent Gainsboroughs or some of the good Italian paintings, for example, and hang Lindauers in their places, particularly when they are inferior, said Mr Tomory, the Art Gallery director, today. ... 'It is a Victorian idea to suggest that a gallery hangs everything it possesses,' said Mr Tomory. ${ }^{57}$

Tomory pointed out that even the British Museum only showed part of its collection at any one time. As noted earlier, at the time of his arrival Tomory spoke approvingly of the improvement seen at the York when a store room was built and the 'rather bad pictures' that had previously been on permanent display in the main gallery had been placed in storage, from whence they could be drawn on selectively. ${ }^{58}$ Tomory aimed to bring the Gallery up to international standards, and modelled his display practices upon those of European galleries, and the galleries where he had worked before coming to New Zealand. As a Weekly News writer observed in 1959: 'No longer are the exhibits hung, as regularly as stamps in an album, along a straight expanse of wall; as in the best overseas galleries, there are bays with all the enticement of a winding road and finally gracefully curving stairs to an irregularly shaped floor under a skylight. All the skill of a good shop-window display has been used by the gallery's two

\footnotetext{
${ }^{56}$ Daniel Hay, Letter to the Editor, $N Z H, 24$ August 1960, p. 8.

57 'Lindauers inferior says Mr Tomory', Star, 29 July 1960, p. 1.

${ }^{58}$ 'New gallery director has the right experience', Star, 8 March 1956, p. 4.
} 
professional directors. ${ }^{\prime 59}$ After his return from a trip to Europe in 1960-1961, Tomory told the Auckland Star that Aucklanders had 'nothing to be ashamed of in their art gallery in layout and appearance ${ }^{\prime}{ }^{60}$

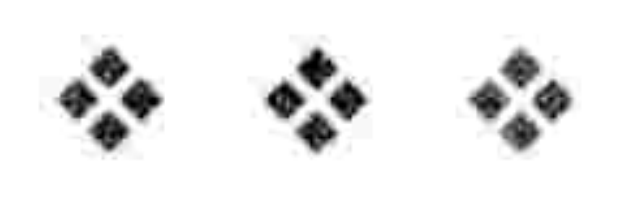

Tomory's acquisition policy was founded upon an aesthetic theory which he described as an 'important overall idea' that superseded the prosaic concerns of building and maintaining a collection:

Quite simply, it is not sufficient to purchase any English 18th Century portrait, or any Italian 16th Century painting, it must be one which will 'work' in New Zealand.

By 'work' one means that such a painting must have some quality which transcends its regional or period associations, and will exist as a good painting, removed 12,000 miles from its country of origin, seen in a more brilliant light and surrounded by an environment to which it is entirely unrelated-except for one thing, the culture which this fatherest flung of European communities still practises. ${ }^{61}$

By 'work' Tomory meant that any acquisition had to be considered in terms of whether it would be understandable according to the aesthetic standards that had developed during the century of European civilisation in New Zealand. Tomory argued that unlike music, drama and literature the visual arts do not travel well in reproduction, and, given the distance from other centres, New Zealanders had few opportunities to see masterpieces of European art. He suggested that the New Zealand audience-'this European community which is further from the sources of its culture than any other in the world' - had

\footnotetext{
59 'On world's art map', Weekly News, 22 July 1959, p. 22.

60 'Art gallery compares very well', Star, 7 March 1961, p. 3

${ }^{61}$ Tomory, 'The Art Gallery moves to its goal' (1958).
} 
developed 'an attitude to art which is different in some way or other to the main European aesthetic philosophy'. ${ }^{62}$

Tomory did not see this isolation as the only factor that might contribute to the evolution of a unique aesthetic standard. His theory was based on the premise that aesthetic appreciation was bound up in the 'day to day, year by year, accretion of ocular experience' ${ }^{63}$ By visually experiencing our surroundings, he argued, we develop a way of looking at things:

The perceptive New Zealander, as he goes to work, to the beach at weekends, to the country for holidays, acquires an intimate visual vocabulary of the natural and man-made forms which confront him. ... What is sometimes referred to as 'A bump for locality', or, 'getting the feel of the place', are merely phrases for describing this visual knowledge ...

Nature, as well as the man-made town, provides a similar series of contacts for which I now wish to substitute the word 'totems'. The Oxford Dictionary says the word totem may be applied to an animal or natural object which is sometimes considered to be ancestrally or fraternally related to the tribe. I am going to suggest that the meaning of totem may be reasonably extended to include an aesthetic relationship when the word is applied to the European civilisation..$^{64}$

The art of landscape, Tomory maintained, was one of the 'most powerful and imaginative totems to be raised in Europe'. ${ }^{65}$ The conception of landscape, he continued, had been reshaped over time, according to society's relationship to the land:

civilizations, countries, continents and islands with their different natural characteristics, their varying economies, proportions of urban and rural populations, their mental processes, all will conspire with geology, flora and climate to produce subtle distinctions in defining this relationship between man and land.... Anyone who has spent much of his or her life

\footnotetext{
${ }^{62}$ Tomory, Landfall (1958), p. 153.

${ }^{03}$ Ibid., p. 154.

${ }^{64}$ Ibid., pp. 154-155.

${ }^{65}$ Ibid., p. 155.
} 
in one country develops, subconsciously, a strong attachment to the land. I am not talking here of that Kiplingesque religion called 'patriotism', but of a much stronger emotional and spiritual connection between man and the land he lives in. In its simplest context, one may think of the farmer scooping up a handful of earth ... But a more subtle relationship exists through the eye. ${ }^{66}$

'In a country like New Zealand', Tomory continued, 'where the towns are only just becoming entities and still contain little architecture of note, the land must still provide a great number of those visual totems which, by their proportions and monumentality, their visual and tactile qualities, provide the New Zealander with some kind of aesthetic yardstick. ${ }^{\prime}{ }^{7}$ The lack of European masterpieces, and the impress of the landscape, concluded Tomory, must have produced a unique New Zealand aesthetic.

Tomory elaborated this theme in a 1959 article in the Connoisseur:

If the point is admitted that the visual arts depend on ocular experience, not only of themselves but of all the elements of an environment within which they were produced, then the question may be posed: Is the public collection of art a passive repository of segregated images of various cultures, or is it an active unity of images expressing a significant influence on the community within which they are placed. By selecting an extreme example, say that of a painting of the Persian Sybill by an inconsiderable Italian settecento artist being placed in a public room in the Falkland Islands, or in a similar Baroque villa in Italy, then the first situation produces a passive totem and the second an active one. ${ }^{68}$

This, then, is what Tomory hoped to achieve with the Gallery's permanent collection -'an active unity of images expressing a significant influence on the community'. But what influence did he intend the collection to exert? Tomory wrote proudly in this article that the Gallery was now in the position to provide the community with 'an active set of totems for its own adaptation of the

\footnotetext{
${ }^{66}$ Ibid., p. 156.

${ }^{67}$ Ibid., p. 157.

${ }^{68}$ Tomory, Connolsseur (1959), p. 9.
} 
European culture'.69 In Landfall Tomory noted that although New Zealanders were exposed to visual totems with every experience of their environment, they may lack the ability as artists to translate these totems in terms of paint, or as viewers to recognise the translations and respond to the message being communicated. This was the point at which the permanent collection became crucial. Good examples of European artworks-examples which 'worked' in New Zealand - would according to Tomory's theory act as 'touchstones', enabling New Zealanders to see 'how the totems belonging to land or town may be translated into paint. ${ }^{70}$

In these articles, Tomory was quick to point out what he was not saying. He was not saying that when an artwork left France, and arrived in New Zealand, it ceased to be an artwork:

There are obviously aesthetic fundamentals in the definition of a work of art which are operable and valid anywhere to any European. So that what I would like to discuss is not the validity of a painting as a work of art, but rather the significance of a work of art when it is placed in a quite different environment to that in which it was created, and seen by a people isolated in the main from the resources which produced it ... ${ }^{71}$

Nor was he saying that due to the visual predominance of the landscape in this country, New Zealand audiences would not be able to appreciate subject pictures or works dealing with urban European life. Nor was he saying that all works are inextricably tied to their place of origin; as he noted in the Connoisseur, there are 'a great number of works of art which transcend their environmental limitations, and these works are not necessarily masterpieces but are conceived in periods or at moments of artistic integrity and honesty. ${ }^{72}$ What he was suggesting was that

\footnotetext{
${ }^{69}$ Ibid., p. 10.

70 Tomory, Landfall (1958), p. 163.

71 Ibid., p. 153.

${ }^{72}$ Tomory, Connoisseur (1959), p. 9.
} 
many art works are regionalised. He gave the 'visionary landscapes' of Samuel Palmer as an example, which 'although they still remain works of art when seen in Paraguay, will lack that peculiar felicity which they have when the spectator is familiar with and sympathetic to the environment in which they were created. ${ }^{\prime 73}$ He noted that style could also be regionalised: 'a brush stroke of a certain tone of colour can be as much tied to its original environment as any representational feature. ${ }^{174}$ As will be shown in the following two chapters, this concern with regionalism was reflected in Tomory's exhibition programme (most particularly, the 1961 exhibition Painting from the Pacific) and in his writing on New Zealand art. What appears here as a rather esoteric theory is in fact informed by a belief in the regional nature of art that underlaid Tomory's art-historical approach.

Tomory's ambition was to create an opportunity for New Zealanders to see examples of European and New Zealand painting and sculpture together and relate the two. By seeing how visual totems had been transcribed in Europe, New Zealander viewers (and artists) might come to be able to see how this could happen in New Zealand; through the European works, New Zealanders could come to understand their indigenous art. ${ }^{75} \mathrm{It}$ is difficult to assess how strictly Tomory followed this theory, but it is possible to detect some areas in the collection where purchases of international work may have had specific local resonance. The addition of Henri Hayden's cubist still-life painting, Still-Life with Guitar, Bottle of Bass and Fruit (1918, purchased in 1958), for example, reflects the contemporary interest among New Zealand painters in cubism. Hayden's painting was supplemented by a small number of prints by Villon, Picasso and

\footnotetext{
73 Tomory, Landfall (1958), p. 158.

${ }^{74}$ Ibid.

${ }^{75}$ Tomory used the term 'indigenous' to describe artists who came to artistic maturity in New Zealand. See Tomory, Contemporary painting (1964), for examples of this usage, and my art history honours paper, 'Tomory's texts: a discussion of Peter Tomory's New Zealand writings, 1956-1968', available in the art history disciplinary library at Victoria University of Wellington, for a discussion of this topic.
} 
Braque. Tomory made strong connections between Woollaston and German expressionism, noting the roles that Flora Scales and Mina Arndt played in this transaction of influence. This may have encouraged his acquisition of 20thcentury German prints, which is also inflected by the donation in 1961 of a significant number of works by Arndt by John and May Manoy. Equally, however, Tomory bought works not because they could be linked to contemporary practice in New Zealand, but because an opportunity presented itself for him to acquire a quality piece, as was the case with Jacob Epstein's The Rock Drill, as discussed below.

\section{$\therefore \div$}

In 1960 the Auckland City Council granted Tomory funds to make a four-month buying trip to Europe, the most significant commitment to the permanent collection during Tomory's tenure. Writing to F.N. Ambler (chairperson of the Parks and Library Committee) to arrange his purchasing finances, Tomory indicated that the Mackelvie Trust had given him $£ 2,500$ and asked whether the Edmiston Trustees could be approached for a similar sum, as:

the permanent collection would benefit considerably from a number of pictures of high quality, which are at the moment lacking and a personal visit to the European art markets presents a golden opportunity for viewing and selecting such paintings. ... Such a sum, coupled with my overseas visit would make it possible for me to consider works, which are now far beyond our reach, and it is paintings of this value and quality which are so badly needed in our collections. ${ }^{76}$

In addition to acquiring works, Tomory used the trip as an opportunity to reestablish links with friends and colleagues, to tour art galleries and museums

\footnotetext{
${ }^{76}$ Peter Tomory, letter to F.N. Ambler. 1 April 1960, AAG archives.
} 
(the German Federal Government granted him $£ 115$ to visit galleries in Western Germany) and to give lectures on New Zealand and New Zealand art. ${ }^{77}$ It was also a chance to recharge his cultural batteries, as he wrote Nikolaus Pevsner:

I leave for a visit to Europe in a fortnight's time and shall be in London during November and December. I am looking forward to it very much as one gets so out of touch, not so much with contemporary events, but with keeping one's standards high in a country where one sees very little on the masterpiece level. ${ }^{78}$

While things did not go all his way on the buying trip (a cable sent to the Gallery staff reads: 'Constable small powerful 4300 pounds if Mackelvie cable interested transparency will follow stop confirming Bassano no delay possible nuts repeat nuts lose this bargain. ${ }^{79}$ ), Tomory purchased more than 20 works, spending a total of approximately $£ 8000 .^{80}$ The new works were extensively reviewed in the Quarterly (where Tomory and other staff members wrote short pieces placing the new acquisitions in their art-historical contexts), and also profiled in the Auckland Star. The acquisitions were described as a 'major advance in the standard of the gallery's collection' and evidence that 'despite the soaring prices of both old master and modern art, good works can still be bought at moderate prices. ${ }^{81}$ Tomory's discussion of the new works in the Auckland Star reflects his collection policy; each work or group of works was discussed in terms of how it complemented or augmented the permanent collection. Thus Leandro Bassano's Seasonal allegory with Adam and Eve (c. 1580) was an important addition to the collection of landscape paintings, as it represented the Northern Italian

\footnotetext{
${ }^{77}$ Peter Tomory, letter to the Auckland Town Clerk, 1 February 1960, AAG archives.

${ }^{78}$ Peter Tomory, letter to Nikolaus Pevsner, 18 October 1960, AAG archives.

${ }^{79}$ Peter Tomory, cable to Auckland City Art Gallery staff. 8 December 1960, AAG archives. Tomory's emphasis.

80 'Major purchases lift City Gallery standard', Star, 16 March 1961, p. 4.

${ }^{81}$ Ibid.
} 
school of the late-16th and early-17th centuries. ${ }^{82}$ Likewise Pietro Paolini's The Fortune-Teller gave the Gallery a piece from the realist genre of the same period, while Marco Ricci's A rocky landscape with figures represented the influential picturesque school of landscape painting of the early 18th century. The collection of northern European painting was strengthened by Tomory's purchase of Pieter Breughel the Younger's A Village Fair (Village festival in honour of St Hubert and St Anthony), and Hendrik Mommers' Landscape with peasants, which he described as representing, respectively, the narrative style of painting typical of Flemish art and the influence of Italian painting on Dutch art in the 17 th century.

Tomory returned with prints from a range of periods, which augmented existing groups in the permanent collection. The old master holdings were boosted by the addition of four Rembrandt etchings, and an etching by Piranesi was added to the collection of that artist's work. Two aquatints by Rouault, a lithograph by Redon and a drypoint etching by Marcellin Desboutin were added to the collection of modern French prints. Tomory also purchased four works to add to the collection of early New Zealand prints, in accordance with the acquisition policy established in 1956.

In regard to contemporary work, Tomory bought only British artists. He acquired paintings by Josef Herman (whose drawings had been shown at the Gallery in 1956), Robert Bevan and Jacob Bornfriend. The major coup, however, was the acquisition of Jacob Epstein's The Rock Drill (1913-1916). Tomory described the bronze as 'one of the most significant works of the modern era', and noted that the gallery had been lucky to secure the work, given other galleries' interest: the director of a new museum of modern art in Vienna, he recounted, was 'most annoyed that we got in first for that one.' ${ }^{83}$ The Rock Drill,

\footnotetext{
${ }^{82}$ At the time of its purchase, this work was known as Landscape with a hunting party.

83 'Major purchases lift City Gallery standard', Star, 16 March 1961, p. 4.
} 


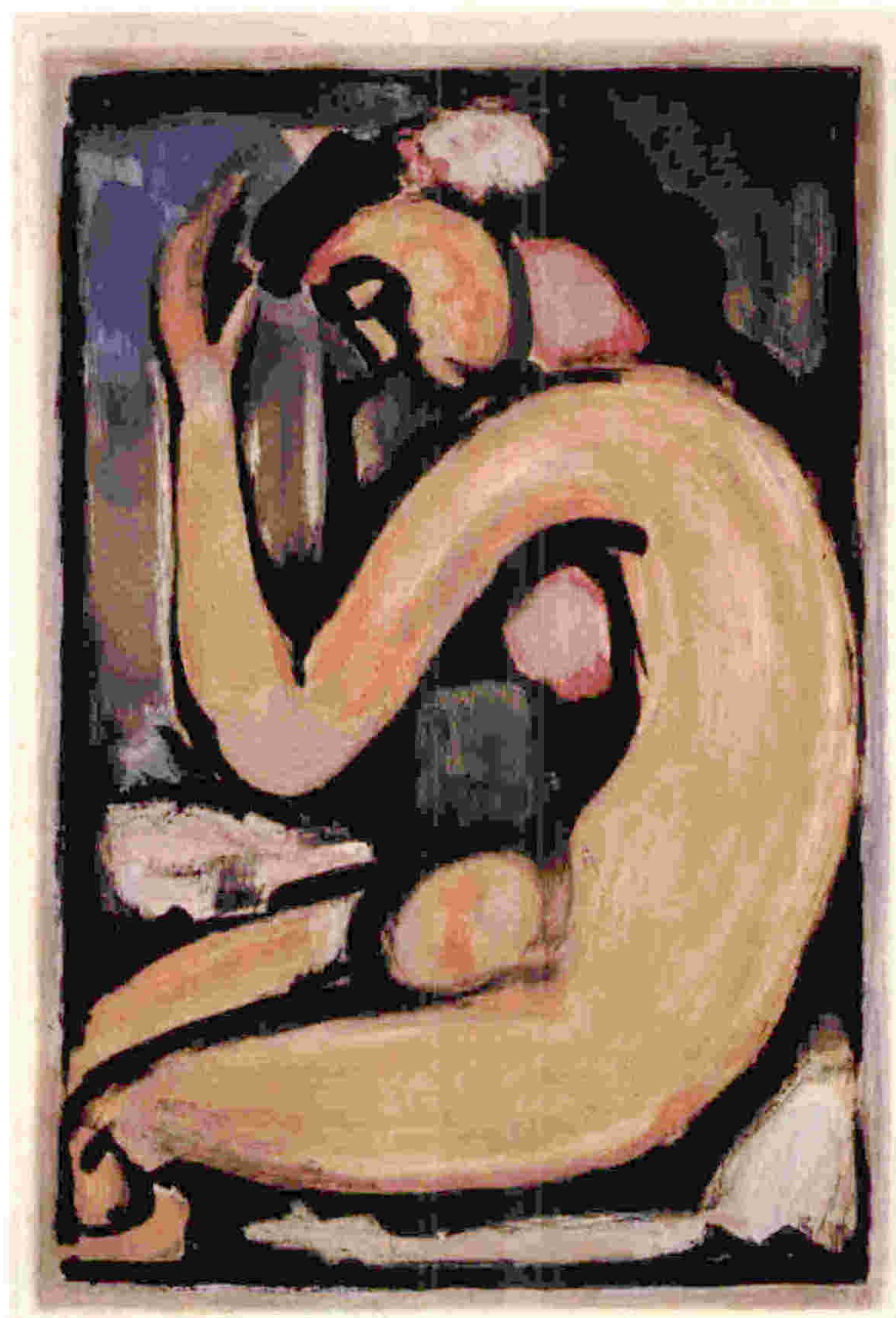

Georges Rouault, Nude in profile, 1936, colour etching with aquatint and roulette, 305 × 203 mm, collection of the Auckland Art Gallery Toi o Tàmaki. This is one of two etchings by Rouault acquired for the Gallery on Tomory's 1961 buying trip to Europe. 
for Tomory, was an important addition to the Gallery's 'excellent' collection of modern sculpture, and a key work that marked sculpture's first break from naturalistic representation. The collection of modern sculpture, initiated by Westbrook, was a highlight of the Auckland collection in the 1950s and 1960s, and was described as the best collection of its type in the southern hemisphere. ${ }^{3 t}$

The controversy surrounding the purchase of Barbara Hepworth's Torso II in 1963 has been well documented. ${ }^{85}$ The controversy took two forms. First, and most visibly, there was a public outcry over the expenditure of 950 guineas on a piece of modernist sculpture. Secondly - and more interestingly in the context of a discussion of the growing professionalism in art administration in this periodthe decision to cancel the purchase of a work that Tomory had recommended was interpreted as an expression of a lack of confidence in Tomory's professional judgment. Tomory himself saw the Council's action in this way, telling the New Zealand Herald he assumed the action was an indication of a feeling of noconfidence in his ability to select works of art for the gallery. ${ }^{\prime 86}$ At this point the issue of a purchases advisory committee, last raised in the 'attempted coup' of 1955, emerged once more.

The drawn-out argument over the purchase of Torso II ended when an anonymous donor purchased the work to be placed on long-term loan to the Gallery. Attention now shifted from the work itself to Tomory's selection of the sculpture and his governance of the collection. In order to force the Council to

\footnotetext{
84 'Tomory denounces talk of Gallery clique', NZH, 25 November 1964, p. 2.

${ }^{85}$ See, for example, Jim Barr and Mary Barr. When art hits the headlines, Wellington: National Art Gallery, 1987. Hereafter abbreviated as J. Barr and M. Barr, When art hits the headlines (1987).

90 'Sculpture decision short-sighted says Mr Tomory', NZH, 12 July 1963, p. 1.
} 


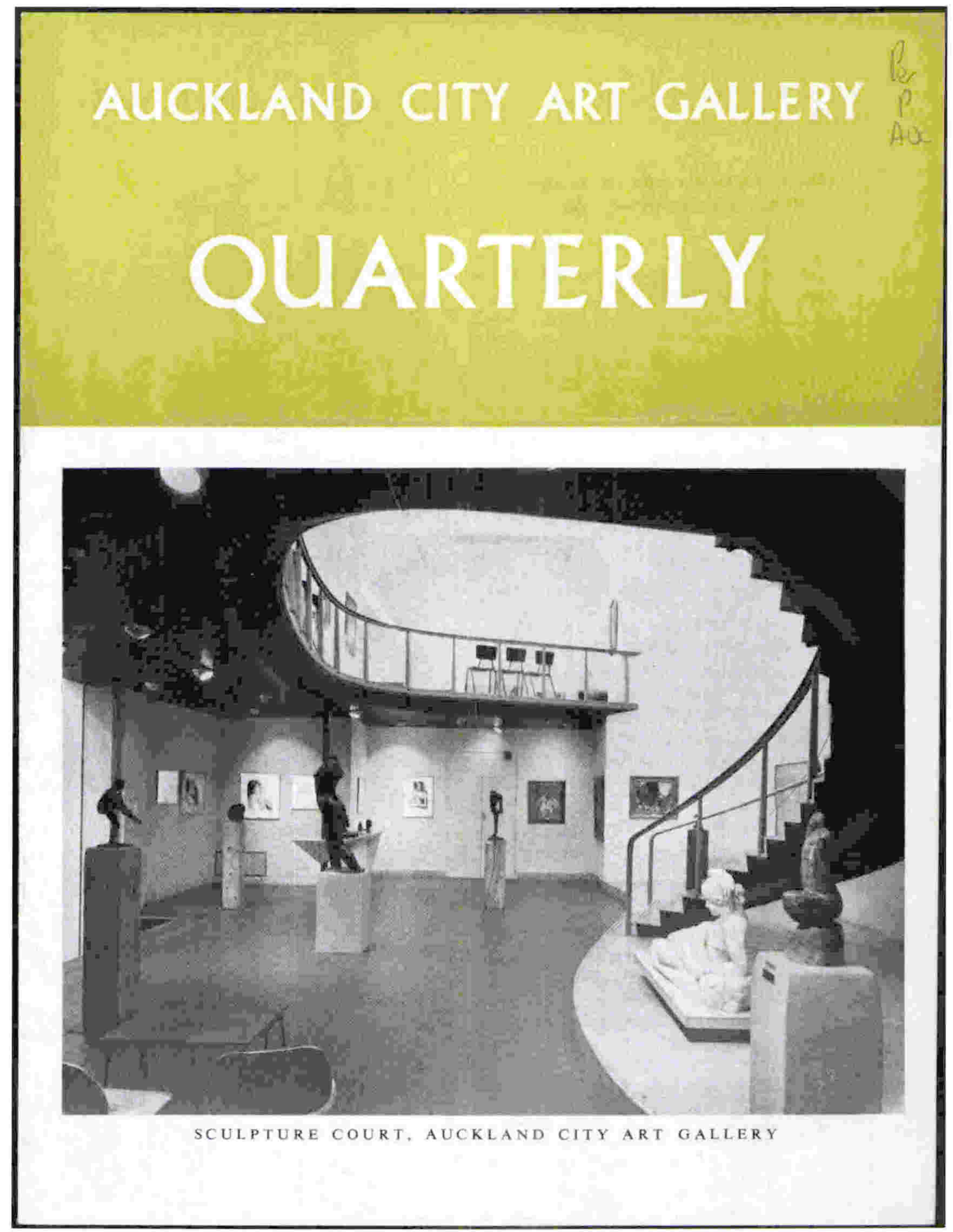

Cover of the Auckland City Art Gallery Quarterly, no. 5, 1957, showing the sculpture court. Works on show include three bronzes from the collection of international modernist sculpture developed by Westbrook and Tomory: Degas' Femme Mettant Son Bas (acquired 1956), Maillol's The Woman who walks through the water (Mackelvie Trust collection, acquired 1957), and Rodin's La Grande danseuse (1913, acquired 1956). 
publicly confirm its confidence in Tomory, Councillor Ambler put a motion before the 22 July Council meeting which read: 'That the council reaffirms its confidence in the director of the art gallery and notes with satisfaction the high reputation gained by the gallery both in New Zealand and overseas under his administration. ${ }^{\prime 87}$ Deputy Mayor A.O. Glasse also put a motion before Council, seeking the re-establishment of the arts advisory committee to advise on purchases of over 500 guineas. ${ }^{88}$ Glasse envisaged a committee of 'art authorities' that would consider Tomory's recommendations before they went to the Parks and Library Committee. ${ }^{89}$

Discussion of the motions at the Council meeting did not begin until 10 p.m., but despite the late start members of the public packed the room to witness the debate..$^{90}$ Presenting his motion, Glasse stated that it was not meant as a criticism of Tomory's performance as director; rather, he 'honestly believed', as the New Zealand Herald reported, 'that a properly constituted advisory committee would assist the director and act as a shield. ${ }^{\prime 91}$ Quoting a 1959 report in which Tomory said that the advisory committee of the time was working well, Glasse suggested that if Tomory gave 'proper consideration' to the proposal to reestablish of the advisory committee, he would see its worth and welcome it.

Ambler argued that the present situation had arisen because one councillor-who was not an art expert-had objected to the Hepworth sculpture, and asked what could be gained by appointing an advisory committee which knew less about the subject than the person they were meant to support. ${ }^{92}$

\footnotetext{
87 'Confidence motion proposed - Art Gallery director', $N Z H, 19$ July 1963, p. 1.

88 'Art advisory group sought', Star, 16 July 1963, p. 1.

${ }^{89}$ Ibid.

90 'To examine advisory plan—Public packs Torso debate'. NZH, 23 July 1963, p. 1.

${ }^{91}$ Ibid.

${ }^{92}$ Ibid.
} 
Ambler was defending Tomory's professional judgement and the autonomy of the Director's position:

The council cannot put a man in charge of a gallery and allow him no authority. Perhaps we should have advisory committees for all departments. Can you imagine the city librarian, the parks superintendent or the city engineer being asked to take advice? ${ }^{93}$

After lengthy discussion Glasse's motion was put to the vote and passed 16 votes to 4. After this, Ambler stood to put his motion asking for the council to express its confidence in Tomory, who, he said, felt his reputation to be at stake. ${ }^{9.4}$ At this point Robinson intervened, refusing the motion, and saying that all speakers had noted that the discussions over the purchase did not imply a lack of confidence; it was officially noted that neither the Council, nor any Councillor, had at any time criticised Tomory for his administration of the Gallery. The Parks and Library Committee was asked to report to the council on the advisability of reinstating a purchases advisory committee to assist the director.

Tomory was strongly opposed to the creation of any such committee. He asserted that the previous advisory committee (dissolved in 1959) had effectively not acted as advisors, as 'despite the individual interest in the visual arts, no members of the committee had the qualifications or experience to do so. ${ }^{95}$ Tomory wrote a memorandum to the Town Clerk, protesting vigorously against the proposed advisory committee. He noted that his conditions of appointment had not mentioned the committee, and stated that 'nor would anyone of my profession expect there to be one, since no such committee exists in any

\footnotetext{
${ }^{33}$ Ibid.

94 Ibid.

95 'Mr Tomory against advice procedure', Star, 19 July 1963. p. 3.
} 
municipally controlled Gallery in England. ${ }^{\prime \prime}$ Tomory also declared that if he had known of the existence of an advisory committee, or known of the attempt in 1955 to establish one, he would not have applied for the position. He argued that his training and experience qualified him to make recommendations; that his contacts in England and Europe gave him access to professional knowledge which he consulted before making recommendations, making an advisory committee redundant; and that with Geoffrey Rix-Trott already a co-opted member on the Parks and Library Committee, an advisory opinion was readily available. Tomory implied that the Gallery worked better without an advisory committee; a professional director, he wrote, can resist the pressure of outside influences, opinions and cliques by invoking policy, allowing the gallery to 'enjoy a reputation of authority and dignity'. ${ }^{97}$ Laymen, in his opinion, often found resisting such pressures impossible. Any advisory committee, he reasoned, would through its vulnerability to outside pressures create 'unnecessary obstacles and difficulties' for the director. ${ }^{98}$

Tomory's deepest concern was over the council's confidence in his professional ability. He described purchases advisory committees as anomalous; to his mind, a director who requested such a committee lacked confidence in his own abilities, and a director who had one imposed upon him had been given a sign of others' lack of confidence. ${ }^{99} \mathrm{He}$ noted that in previous positions he had managed much larger sums than the 'minute proportion' of its income that the Council made available for additions to the collection, and that the increasing value of the collection he had assembled testified to the quality of his recommendations. Tomory concluded his memorandum by stating: 'To suggest

\footnotetext{
${ }^{96}$ Peter Tomory, 'Purchases Advisory Committee', memorandum to the Auckland Town Clerk, 1 August 1963.

${ }^{97}$ Ibid.

98 Ibid.

${ }^{99}$ Ibid.
} 
re-appointing [an advisory committee] infers plainly, that the committee has lost confidence in its director, and that it is unwilling to accept the responsibility of trusting the director in the face of uninformed public criticism.' 100

The Park and Library Committee's report pronounced against the advisability of re-establishing a purchases advisory committee. ${ }^{101}$ Rix-Trott had already been co-opted to provide an 'independent, informed view on proposed additions', and the committee recommended that John Stacpoole (former chairman of the Auckland Gallery Associates and a current member of its selection committee) also be co-opted to advise with him. ${ }^{102}$ This decision was a quiet victory for the autonomy of the professional art gallery administrator in New Zealand.

\footnotetext{
100 Ibid.

${ }^{101}$ Minutes of the Parks and Library Committee meeting, 5 August 1963, p. 2A. AAG archives.

102 Ibid.
} 


\section{Temporary exhibitions}

In addition to the display of the permanent collection, the Gallery also ran an ambitious programme of temporary exhibitions of New Zealand and international art, both imported and generated in-house. This chapter opens with a consideration of the Gallery's position as the primary facilitator of touring exhibitions in this period, fulfilling a responsibility that the National Art Gallery had neither the financial nor staffing resources to carry out. The impact of these exhibitions is considered, using the 1958 show British abstract painters as a case study. Tomory's purging of amateur work from the exhibition programme is then examined, focusing on Tomory's continued resistance to showing the Kelliher Prize exhibition. In place of amateur exhibitions the Gallery instituted a regular programme of exhibitions of historical and contemporary New Zealand art selected by Gallery staff. This section ends with a consideration of the place accorded to abstract art in the Gallery's exhibitions of New Zealand art. Finally, the Gallery's 1961 show Painting from the Pacific is examined as an important early example of contemporary New Zealand art being placed an international context.

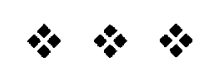

Tomory quickly instigated a change in the Gallery's exhibition programme, introducing a policy markedly different to Westbrook's. Tomory sought to reduce the number of temporary exhibitions at the Gallery and increase their quality. McCahon, recalling Westbrook's tenure, told Gordon H. Brown: 
There was remarkably little happening ... in the way of it being an art gallery. There was everything happening in the way of it being a place where the Rose Society, the Carnation Society would hire one end and the other end of the main gallery, and ... have compost mixing demonstrations. All that sort of thing. Well, okay, this was Westbrook and it was-he managed this extremely well. He had an incredible talent for getting people to know where the Art Gallery was. ${ }^{1}$

Westbrook's policy was directed at increasing visitor numbers. Tomory, arriving after the Gallery had attained some level of public profile, wanted to reach a higher standard of temporary exhibition, on a par with overseas galleries; one of his methods of achieving this goal was the introduction of a programme of touring exhibitions imported from overseas. Tomory's emphasis upon travelling exhibitions, and the remarkable work that the Gallery did in this area during this period, reflects his time with the Arts Council of Great Britain where one of his primary tasks had been the management of touring exhibitions.

In March 1963, in an Art Galleries and Museums Association of New Zealand (AGMANZ) meeting, Tomory introduced Frederick Turnovsky, who was speaking on the Arts Advisory Council's position on touring art exhibitions. ${ }^{2}$ Tomory began by asking 'How necessary are exhibitions?' - a question which seems self-explanatory until one considers that the temporary exhibition was a relatively new phenomenon. While temporary exhibitions have been held in art institutions since the 19th century, it was not until after the Second World War that they became 'the most prominent form of entertainment and tuition in the visual arts.' ${ }^{3}$ As Mary Kelly notes, the rise of the temporary exhibition indicated a

\footnotetext{
'Brown. interview with Colin McCahon (1979), tape 3, p. 9

2 'Travelling exhibitions and the Arts Advisory Council' (transcript of a talkgiven to AGMANZ members), AGMANZ newsletter, no. 15, May 1963, pp. 7-10. Hereafter abbreviated as 'Travelling exhibitions and the Arts Advisory Council' (1963). The Arts Advisory Council, founded in 1960, was the forerunner to the Queen Elizabeth II Art Council of New Zealand.

${ }^{3}$ Mary Kelly, 'Re-viewing modernist criticism' in Bryan Wallis (ed.), Art after modernism: rethinking representation, New York and Boston: The New Museum of Contemporary Art and David R. Godine, 1984, p. 87.
} 
'significant shift in the system of patronage from the private sector to institutions funded by the state. ${ }^{4}$ Tomory's view of touring exhibitions as a way to supplement New Zealand's poor public collections and to increase public appreciation of the arts is consistent with the Arts Council of Great Britain's practice of touring exhibitions to regional museums for the same reasons. ${ }^{5}$ Tomory noted in his 1963 AGMANZ address that few touring exhibitions had come to New Zealand between 1880 and 1956: since his appointment the Gallery had held 40 exhibitions of work obtained from overseas, and toured 55 exhibitions around New Zealand.

Tomory listed the impediments to generating exhibitions: where to find suitable works; how to convince owners to lend works, especially given New Zealand's place 'on the rim of the world'; the 14 days that it took to get works to and from New Zealand, which ate into loan periods; the costs of shipping and insurance. ${ }^{6}$ As Tomory noted: 'Each tour was a gamble as regards cost, and the Auckland Art Gallery was out of pocket to a considerable extent if the gamble was not successful.'7 The Department of Internal Affairs had occasionally assisted with funding, but the advent of the Arts Advisory Council and the Visual Arts Committee (which had made $£ 3000$ available for travelling exhibitions) had considerably reduced this gamble.

In his address, Turnovsky emphasised the importance of travelling exhibitions as the 'most important and rewarding short-term means of

\footnotetext{
4 Ibid.

${ }^{5}$ Tomory stated in his address that 'even if all the publicly owned pictures [in New Zealand] were brought together in one place, they would not comprise a major collection.' This created, in his opinion, the lag in appreciation of the visual arts in this country, as compared to literature and music. 'Travelling exhibitions and the Arts Advisory Council' (1963), pp. 7-8.

${ }^{6}$ Ibid.. p. 8.

' Ibid. In 1957 the Gallery imported nine exhibitions for the cost of approximately $£ 2000$, of which amount only half was recovered from participating galleries and through grants from the Department of Internal Affairs. In 1959 the imposition of import restrictions prevented the Gallery from bringing in any overseas exhibitions.
} 
stimulating the visual arts. ${ }^{8}$ Interestingly, Turnovsky identified one of the benefits of travelling exhibitions as the creation of 'an awareness of quality [which is] the first step towards spreading the desire among those who support galleries to improve their own permanent collection."9 This accords with Tomory's oft-repeated statement that the role of the Gallery was to stimulate the public's interest in the visual arts by showing works of the best possible quality, which would encourage people to support the visual arts independently. Turnovsky also noted:

\begin{abstract}
Some time last year, the A.A.C. called a meeting of art gallery administrators to see whether agreement could be reached on a comprehensive policy on travelling exhibitions and on the setting up of an organization to tour them nationally. The outcome was meagre, to say the least. Galleries seem content to leave the initiative for selecting and organizing overseas exhibitions largely to the Auckland Art Gallery, and in particular to Mr. Peter Tomory, and to a lesser extent to the National Gallery in Wellington. This places a heavy responsibility on Mr. Tomory's shoulders, but if he is willing to bear it, and everybody agrees that should do so, no one will object, and, in fact, we will all be greatly indebted to him. ${ }^{10}$
\end{abstract}

Tomory wrote in a 1957 issue of the Quarterly that the first travelling shows generated by the Gallery went on tour in 1956, and since then the scheme had developed into a full time service. ${ }^{11}$ He explained that the Gallery in this time had undertaken restricted tours of expensive overseas exhibitions (including Henry Moore and XXth century French painting from the collection of Erick Estoric) and larger tours of exhibitions of original prints and drawings (including Drawings by four realist painters: Jack Smith, John Bratby, Derrick Greaves, Edward Middleditch, Ecole de Paris prints and Old master drawings). The first touring survey

\footnotetext{
${ }^{8}$ Ibid., p. 9.

${ }^{9}$ Ibid.

${ }^{10}$ Ibid., pp. $9-10$.

"Auckland City Art Gallery Quarterly, no. 5, 1957. p. 6.
} 
of New Zealand painting, Eight New Zealand painters, was also staged in 1957. Tour destinations included Hamilton, Gisborne, Tauranga, Napier, Wanganui, Wellington, Christchurch, Timaru, Dunedin and Invercargill; the average cost of each show was between $£ 6$ and $£ 7$ (a hire charge of $£ 1$ per week plus a share in transportation costs). In his address to AGMANZ, Turnovsky suggested that galleries with limited budgets would be better off using their funds to show travelling exhibitions rather than buying works they may later regret purchasing.

Tomory drew on his contacts in Britain to bring shows to New Zealand. One of his first letters back to England after his arrival was to Jackwood Palmer, a colleague at the Arts Council of Great Britain, asking him to support his request to Philip Iames (director of the Arts Council) to send some of the Council's exhibitions out to New Zealand, and also asking if Palmer would be willing to help assemble an exhibition of drawings by contemporary British painters, also to be sent to Auckland. ${ }^{12}$ Likewise, he asked another ex-colleague, Joanna Drew, to catalogue the works included in the 1956 show XXth century French painting from the collection of Erick Estoric. ${ }^{13}$ Travelling exhibitions tended to focus on recent art-Estoric's collection and Drawings by four realist painters: Jack Smith, John Bratby, Derrick Greaves, Edward Middleditch (a show of 'Kitchen Sink' or British realist artists) in 1956, contemporary Australian painting in 1957, drawings by contemporary West Coast American artists in 1962 and modern French sculpture in 1963, to give some examples. Tomory also drew on his contacts with dealer galleries, particularly to supply print shows, which were easily transported and less expensive than painting or sculpture exhibitions. In some cases, such as the 1957 exhibition of Rouault's Miserere series, the Gallery would purchase works from these shows. Tomory's connections proved

\footnotetext{
${ }^{12}$ Peter Tomory, letter to Jackwood Palmer, 20 March 1956, AAG archives.

${ }^{13}$ Peter Tomory, letter to Joanna Drew, 21 March 1956, AAG archives.
} 


\section{AUCKLAND CITY ART GALLERY}

\section{QUARTERLY}

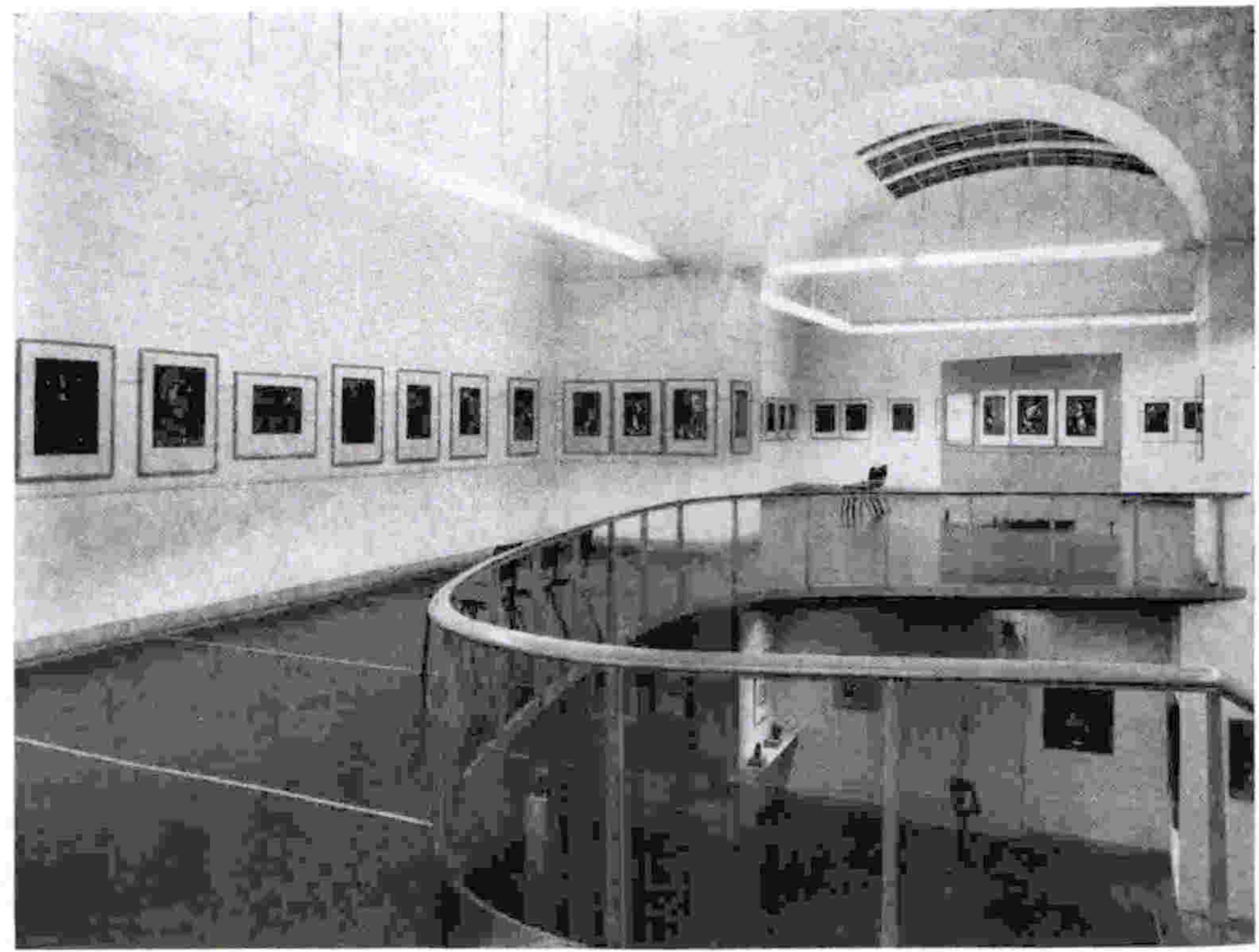

Cover of the Auckland City Art Gallery Quarterly, no. 9, 1959, showing

Rouault's Miserere series on display in the mezzanine gallery in mid 1957. The sculpture court can be seen below. 
invaluable in this area. For example, the Auckland City Art Gallery became the first gallery outside France to show a large body of Picasso's prints from the early 1960s, in the 1964 exhibition One hundred and two linocuts by Picasso. This opportunity arose when Tomory contacted Daniel-Henri Kahnweiler, Picasso's dealer, to enquire about the possibility of showing work by Picasso. Kahnweiler had a show of Picasso's linocuts that had a gap before moving to its next location, and he offered it, along with some earlier linocuts, if Tomory could arrange for the show to be brought out, shown and returned in time to travel to its next destination. ${ }^{14}$

Tomory often reviewed these touring shows, mostly in the journal Home and Building. As the exhibitions were aimed at introducing audiences to modern art, Tomory's reviews were usually short articles introducing the theme of the exhibition and the artists included. Tomory sometimes noted in his reviews that the works available to the Gallery for exhibition were not adequate to communicate the exhibition's message. The 1963 exhibition Sculpture in France, for example, was intended to 'show the New Zealand public the foundation on which the sculpture of this century is based, and to indicate the move away from wholly naturalistic forms, heralding the abstracted forms with which the sculpture of today is largely concerned. ${ }^{\prime 15}$ Unfortunately, the Gallery had been unable to secure works by Villon and Brancusi for the exhibition, which Tomory felt were needed to demonstrate the changes in sculpture before 1914. Although he felt 'better justice would have been done to this fertile period if more works had been available', Tomory concluded that the exhibition had been successful if

\footnotetext{
${ }^{14} \mathrm{I}$ am grateful to Hamish Keith and Gordon H. Brown for bringing the circumstances behind this exhibition to my attention.

${ }^{15}$ Peter Tomory, 'Sculpture in France', Home and Building, vol. 26, no. 6, November 1963, p. 44.
} 
'the work included in it appears as the essential foundation of 20th Century Sculpture.' 16

McCahon's correspondence also reveals the frustration of trying to assemble exhibitions under such limitations. In October 1957 he wrote twice to Ron O'Reilly regarding the 20th century French painting exhibition the Gallery was showing. In the first letter, McCahon wrote that 'The French disappoint-I always expect \& hope for so much. But it will come, when we are established as a gallery in the eyes of the world - then more valuable paintings will be sent.' ${ }^{17}$ Later that month he wrote:

\begin{abstract}
Myself am certain that the show [20th Century French Painting] will disappoint. Tomory says it's a very good example of what you would see in dealers galleries but that doesn't stop the disappointment-we have been fed on the best books \& reproductions that this more ordinary level does disappoint. ... I just wouldn't know what to advise. Probably to take it \& as I said in the telegram - you can't get better for the money and who is likely to put up more-sufficiently more money for a better show. ${ }^{18}$
\end{abstract}

The 1958 exhibition British abstract painting was one of the most influential of the international shows that the Gallery toured. It was especially notable for two reasons: the resistance the Gallery encountered from other public galleries when touring the show, and the influence the exhibition had on local artists. The show was assembled from Metavisual, tachiste, abstract painting in England today, a 1957 exhibition at the Redfern Gallery in London (run by expatriate New Zealander Rex Nan Kivell). There the show included work by Terry Frost, William Gear, Adrian Heath, Patrick Heron, Roger Hilton, Peter Lanyon, Ben Nicholson and Victor Pasmore. Action painting, or tachisme, was the European equivalent of American abstract expressionism. Exemplified by artists such as

\footnotetext{
${ }^{16}$ Ibid., p. 46.

${ }^{17}$ Colin McCahon, letter to Ron O'Reilly, October 1957, private collection.

${ }^{18}$ Colin McCahon, letter to Ron O'Reilly, late October 1957, private collection.
} 
Georges Mathieu, Antoni Tàpies and Alberto Burri, tachiste painting is aggressively physical, characterised by blotches and dabs of colour and heavy impasto, free brushwork, dribbled paint and the application of paint directly from the tube.

British abstract painting, as the exhibition was titled in New Zealand, included many of the painters shown in the original exhibition. ${ }^{19}$ New Zealand audiences had recently been exposed to modern European art to some extent by way of the Erick Estoric collection of French painting and Rouault's Miserere prints. But where these shows had an 'inescapable air of the past', British abstract painting was, as Brown and Keith put it, 'undeniably up to the minute' ${ }^{20}$ The very contemporary nature of the works led the National Art Gallery and the Dunedin Public Art Gallery to refuse to show the exhibition when the Gallery undertook a national tour. The National Art Gallery management committee stated that the exhibition consisted of a 'collection of works of a particularly extreme section of ultra-modernism in art ... people should not be fooled by what is merely extravagant and grotesque in art. ${ }^{21}$ The exhibition, the committee concluded, 'was not considered to merit display in the National Gallery. ${ }^{22}$ It is interesting to note that in both cases the exhibition was shown in alternative venues - the Architectural Centre Gallery in Wellington, and by the Visual Arts Association and the Otago Art Society in Dunedin. As Damian Skinner observes, the decision by the Architectural Centre to take the exhibition after the National

\footnotetext{
${ }^{19}$ Included in the show were: Gillian Ayres, Sandra Blow, Denis Bowen, Henry Cliffe, Bernard Cohen, Robyn Denny, Paul Feiler, Donald Hamilton Fraser, Terry Frost, William Gear, Adrian Heath, Patrick Heron, Roger Hilton, James Hull, Gwyther Irwin. Louis James, Peter Kinley, Peter Lanyon, Derek Middleton, J. Milnes-Smith, Henry Mundy, Rodrigo Moynihan, Victor Pasmore, Ralph Rumney, Frank Avray Wilson and Bryan Wynter.

${ }^{20}$ Gordon H. Brown and Hamish Keith, An introduction to New Zealand painting, 1839-1967, Auckland: Collins, 1969, p. 174. Hereafter abbreviated as Brown and Keith, Introduction (1969).

${ }^{21}$ Cited in J. Barr and M. Barr, When art hits the headlines (1987), p. 23.

22 Ibid.
} 
Art Gallery's refusal shows that the gallery saw itself as the modernist alternative in Wellington, and as 'Wellington's answer to the Auckland City Art Gallery.' ${ }^{23}$

The exhibition had a significant effect on New Zealand painters - an impact some commentators have thought disproportionate to the quality of the work it included. Brown and Keith write:

In retrospect it is hard to believe that the exhibition had the influence it seems to have had, consisting as it did mainly of English imitations of American Abstract Expressionism or tasteful versions of post-war School of Paris abstraction, but whether by coincidence or direct influence the scale of New Zealand painting began to radically alter from $1958 .{ }^{24}$

These changes were non-specific, they concede, but were more marked in the work of Auckland painters. Brown and Keith aver that outside Auckland the effect of the paintings was 'undoubtedly limited' by the manner in which they were presented. ${ }^{25}$ Tony Green has argued that Auckland painters were more attuned to the style of painting presented in the show; observing the number of paintings from St Ives in the exhibition, Green sees the 'nature-abstraction' common to these works as 'coincid[ing] neatly with the predominant direction of McCahon and his immediate circle in the 1950s', and gives the painting of Jean Horsley, Alwyn Lasenby and Freda Simmonds as evidence. ${ }^{26}$

The exhibition does appear to have had some impact on artists outside Auckland. Jonathan Mane-Wheoki has noted that in the early 1960s Ralph Hotere was strongly influenced by modern French painting; asserting that Hotere would have seen British abstract painting, Mane-Wheoki cites his Polaris series as tachiste-

\footnotetext{
${ }^{23}$ Damian Skinner, 'Making modernism: Helen Stewart and the Wellington art scene 1946-1960', Art New Zealand 96, Spring 2000, p. 105.

${ }^{24}$ Brown and Keith, Introduction (1969), p. 174.

${ }^{25}$ Ibid.

20 Tony Green, 'Modernism and modernization' (1992). p. 152.
} 
inspired works. ${ }^{27}$ Justin Paton suggests that the 'significant leap in the quality' of Wellington painter Don Peebles' Wellington Series paintings in the late 1950s may have been spurred by his engagement with the works in British abstract painting, which he helped to hang at the Architectural Centre Gallery. ${ }^{28}$

Critics in the 1950s, noting painters' interest in tachisme, were dubious about the benefit of drawing too heavily on European models. Kase Jackson's abstract paintings, based directly on his response to the show, received particular attention. I.V. Porsolt, in a review of the Gallery's Three abstract painters: Louise Henderson, Kase Jackson, Colin McCahon (1959), observed that Jackson's style showed a loosening of technique and a bolder use of colour in works such as $\mathrm{Hi}$ Lo and R.A.F. Workshop, changes which he attributed to the painter's study of the British paintings. Porsolt did however note that Jackson's enthusiasm for tachisme was not always beneficial for his painting, as some of his works 'demonstrate more clearly than theorising how quickly an exciting novelty can fade into stale gimmickry. ${ }^{29}$

\section{$* *$}

Tomory sought to limit the presence of local and amateur work in the exhibition programme. Under Westbrook, a range of art groups and societies had exhibited in the Gallery, including the Auckland Society of Arts and the Rutland Group. In his first report to the Auckland City Council, Tomory advocated allocating the Lindauer Room as an exhibition space for such groups, thus separating them from the main galleries. Tomory stated he had a 'duty to the public' to stimulate

\footnotetext{
${ }^{27}$ Jonathan Mane-Wheoki, 'Buck Nin and the origins of contemporary Maori art', Art New' Zealand 82, Autumn 1997, p. 62.

${ }_{28}^{2}$ Justin Paton, Don Peebles: a harmony of opposites, Christchurch: Robert McDougall Art Gallery. 1996. pp. 16-17. Hereafter abbreviated as Paton, Don Peebles (1996).

${ }^{29}$ I.V. Porsolt, 'Gallery addition to Festival: three painters exhibit', $N Z H, 3$ June 1959, p. 9.
} 
interest, which could only be done by consistently showing works which had 'stood the test of time and criticism'.${ }^{30} \mathrm{He}$ argued that to act otherwise would in fact be detrimental to the local artist: 'If this week we have an exhibition of the works of Rembrandt in the gallery, and then next week an exhibition of the works of John Smith who, we tell the public, lives next door to you, then I feel that would tend more to cheapen the work of the local painter. ${ }^{31}$

Tomory's actions over the Kelliher Prize exhibition illustrate his stance on the place of amateur work at the Gallery. The Kelliher Prize, sponsored by beer baron Sir Henry Kelliher, was designed to encourage traditional representational landscape painting in the face of the emergent modernist tendencies in New Zealand painting ${ }^{32}$ The inaugural exhibition of Kelliher Prize entries was held at the Gallery in 1956. An extra exhibition space had to be set up in Karangahape Road, and the exhibition was hugely popular, drawing 2500 visitors in its first four days. ${ }^{33}$ Kelliher himself was very pleased with the exhibition's reception, stating that the response both from entrants and the public indicated an 'encouraging interest in realistic and traditional art'. ${ }^{34}$

Others were less enthusiastic. Fairburn was of the opinion that most of the entries were lacking in taste, if not downright vulgar ${ }^{35}$ He lauded Kelliher's generosity and saw some potential in the competition, hoping it might encourage painters who had immersed themselves in 'studio experiments based on avantgarde European movements' to apply themselves to the translation of the New Zealand landscape into art. ${ }^{36}$ However he saw the competition's downfall in the

\footnotetext{
30 'Hothouse of art interest: aim of new director', NZH, 6 April 1956, p. 13.

31 Ibid.

${ }^{32}$ See Richard King, The Kelliher: 67 award winning paintings, Auckland: Orakau House, 1979.

33 'Exhibition of N.Z. art draws crowds', NZH, 28 July 1956, p. 14.

34 'Paintings source of pleasure', NZH, 2 August 1956, p. 12.

${ }^{35}$ A.R.D. Fairburn, 'Afterthoughts on an art exhibition', Home and Building, vol. 19, no. 3, August 1956, p. 72.

${ }^{36}$ Ibid.
} 
attempt to encourage representational painting 'unilluminated by any adequate knowledge of the history of art or awareness of tradition' ${ }^{37}$ Fairburn's conclusion was that:

A public art gallery should pursue a fairly liberal policy and show many different kinds of art-even a certain amount of bad art-so long as its main functions are not interfered with or neglected. The policy established by the new Director - and he is the first person in authority to have insisted upon this very necessary procedure of stating policy-is admirably designed to keep them in proper proportion to one another. One is driven to wonder, therefore, how it comes that a display of this particular sort should have been granted leave to sprawl across the two main galleries of the Auckland Gallery for an extended period, without any voice being raised in protest. If Aucklanders want this sort of thing they had better re-name their gallery the 'Picture Gallery' and leave art out of the question. ${ }^{38}$

Tomory, with his emphasis on high standards in temporary exhibitions, was in fact vehemently opposed to showing the Kelliher Prize entries in the Gallery. ${ }^{39}$ The Kelliher exhibition was antithetical to Tomory's aspirations; in addition to the competition's anti-modernist stance, the Gallery had no role in the selection of exhibits. Tomory had made it clear in his first report to the City Council that he was opposed to holding exhibitions at the Gallery if the staff had no control over the quality of the work included. ${ }^{40}$ However, Westbrook had accepted the Kelliher exhibition, and previous engagements had to be honoured before new policies could be enacted. The 1956 Kelliher exhibition was the only one to be shown at the Gallery-in 1957 the competition shifted to Wellington.

\footnotetext{
${ }^{37}$ Ibid., pp. 72-73.

${ }^{38}$ Ibid., p. 73 .

${ }^{39}$ Tomory made his opposition to the Kelliher exhibition publicly known. Speaking at the Hamilton Art Gallery while the Kelliher exhibition was on show in Auckland, Tomory described the entries as 'every tourist's dream of New Zealand' (at the show, one could see 'every tourist attraction in the country from North Cape to Bluff') but, he declared, they were not actually painting. 'Scenery bedevils N.Z. art', NZH, 3 August 1956, p. 10.

40 Tomory, 'Auckland City Art Gallery director's report April 1956', pp. 5-6.
} 
Despite Tomory's opposition, the possibility of returning the show to the Gallery was raised twice during his tenure. In 1960 the Kelliher Art Trust, citing strong audience response in Wellington, applied to the City Council to show a selection of that year's entries in Auckland in 1961. Tomory opposed the proposal, reiterating that he was reluctant to accept an exhibition if he and his staff were not involved in the selection process. ${ }^{41}$ In 1964 Councillor Ambler tabled a document listing points in favour of showing the Kelliher exhibition in Auckland, including the interest generated by the show, the public demand to see the entries and the Gallery's duty as a public gallery. ${ }^{42}$ Ambler acknowledged Tomory's continued reluctance to show the Kelliher works, noting that granting the application 'would not in any way reflect on the professional competence of the Director.' ${ }^{43}$

In response Tomory repeated his earlier arguments, and cited press reports and professional opinions that supported his stance on the exhibition. He also argued that in the past eight years the Gallery had organised many shows of an international standard, had received favourable mention in the international press, and already had an annual show of contemporary New Zealand work that was of good quality and sufficient to needs. ${ }^{44}$ For Tomory, refusing the application was a matter of preserving the Gallery's reputation both in New Zealand and internationally. Tomory won this debate: a memorandum from the Town Clerk dated 16 March 1964 confirmed that the motion to hold the Kelliher exhibition at the Gallery had been denied.

\footnotetext{
${ }^{41}$ Minutes of the Parks and Library Committee, 31 October 1960, p. 1.

${ }^{42}$ F. N. Ambler, 'Kelliher Art Exhibition: Points in favour of it being shown in the Auckland Art Gallery', undated report tabled at an Auckland City Council meeting c. early 1964, AAG archives.

${ }^{43}$ Ibid.
} 


\section{$\circ \div$}

Tomory also discontinued the solo shows of local artists instituted by Westbrook. Although seen by some as a storm in a teacup, as only two solo shows had actually been held during Westbrook's tenure (Louise Henderson in 1953, and a John Weeks retrospective in 1955), Tomory's decision attracted considerable media attention. ${ }^{45}$ Tony Green has described mid 1957 (when Tomory's decision became public knowledge) as an interesting moment in the establishment of an arts infrastructure in Auckland. ${ }^{46}$ In July that year Peter Webb opened his dealer gallery, the first in Auckland to deal solely in contemporary art. The Auckland Society of Arts (the chief sponsor of solo shows and one of the major exhibiting opportunities for artists in Auckland) had moved to new premises in Eden Terrace, and its new gallery was thought to be one of the best in the city. At this moment Tomory formulated a shift in policy that saw the end of solo shows, while simultaneously creating a new exhibiting opportunity by making the upstairs gallery available to groups of three or more artists.

Tomory explained his decision as an attempt to prevent the Gallery becoming embroiled in local art politics, and to reduce competition with the newly-relocated Auckland Society of Arts. ${ }^{47}$ Tomory also openly stated that the decision was made to protect the Gallery's reputation:

The holding of one-man shows of contemporary artists' work ... reduces the public institution to an Aunt Sally, shied at by every art strata for making the wrong choice of artist, and importuned by every pressure group that wishes to see its particular totem displayed. [In these circumstances] director and gallery become an entity, and the gallery's

\footnotetext{
${ }^{44}$ Peter Tomory, report to the Auckland City Council, 10 March 1964, AAG archives.

${ }^{45}$ See Antony Alpers "No one-man shows' means no-one worthy of them', Star, 23 May 1957, p. 4.

${ }^{46}$ Tony Green, 'Peter Webb's Gallery', Bulletin of New' Zealand Art History, vol. 1, 1972, p. 13. Hereafter abbreviated as Green, 'Peter Webb's Gallery' (1972).

47 "Gallery trying to avoid local "art politics", Star, 17 May 1957, p. 5.
} 
reputation rises and falls according to the ability of the director to pick a winner. ${ }^{48}$

The change in policy also seems to have been made with an eye towards nurturing the emergent dealer gallery scene. Over the next three years artistsusually from Auckland, but occasionally from Wellington and Christchurch took up the offer to show in small groups in the upstairs gallery. In 1960, when The Gallery on Symonds Street (run by Frank Lowe and Don Wood, later known as the Ikon Gallery) seemed to have gained a foothold, Tomory cancelled the group-show policy in the hope of reducing competition between the Gallery and the nascent dealer network. ${ }^{49}$

Tomory's actions here were consistent with his repeated assertion that it was not the role of the Gallery to promote individual artists, and his desire to see a group of dealer galleries emerge in Auckland to fulfil this function. Moreover, he saw staging solo shows as 'rather like laying the accolade on this artist or that artist', a practice he sought to avoid. ${ }^{50}$ Green, writing in 1972, noted that Tomory's refusal to hold one-man shows meant that battles for artistic superiority now had to be fought in the Society's exhibition spaces rather than the Gallery, which might otherwise have placed its still-tenuous professional status at risk. ${ }^{51}$ Green described Tomory's discretion in hindsight as 'very sensible', given the 'growing division between the emerging new professionals and the older generation'.$^{52}$

Green also argued that while Tomory's policy granted him some level of impartiality, the new policy also endangered the validation that a professional

\footnotetext{
48 Ibid.

${ }^{49}$ Brown, New Zealand painting 1940-1960 (1981), p. 56.

${ }^{50}$ Kirker interview, Te Papa version, tape 1.

"Gr Green, 'Peter Webb's Gallery' (1972), p. 13.
} 
institution could confer:

This, no doubt, was a common fear among the younger artists who had seen an institution emerge that was interested in supporting New Zealand art and had confidence in its own professional prestige and judgment. The Gallery had thus validated a professional attitude among artists for the first time and offered a place to show outside the mixed company of the Society exhibitions. ${ }^{53}$

However, as Green has observed in a more recent article, the Gallery under Westrbook and Tomory (with the aid of McCahon, Keith and later Gordon $\mathrm{H}$. Brown) became, in the absence of dealer galleries, the 'only place where the art of new ambitious New Zealand artists who did not fit readily with the scale and style expectations of the hitherto dominant art societies could be seen. ${ }^{154}$ In addition to the annual touring shows of contemporary New Zealand art, initiated in 1957, Tomory's offer to make the first-floor gallery available to small groups was readily taken up by artists. The innovation resulted in a series of exhibitions devoted to the work of contemporary New Zealand painters, sculptors and potters. In 1959 there were 11 exhibitions, with an average duration of three weeks: one of works from a group of anonymous private collectors, two of Wellington painting, three of Auckland painting, three shows bringing together painting, pottery and sculpture and one each of sculpture and prints. In 1960 seven shows were held in the gallery: five painting exhibitions (including one by Canterbury painters), a sculpture show and a show of drawings. The Gallery's objective was to provide a 'continuous exhibition of contemporary art', affording viewers a more complete impression of 'what serious painting is being done throughout the country ${ }^{\prime 55}$ That the first-floor gallery shows were seen as a

\footnotetext{
${ }^{52}$ Ibid.

53 Ibid., pp. 13-14.

${ }_{54}^{54}$ Tony Green, 'Making space', LOG Illustrated, 1ssue 4, Winter 1998, p. 5.

${ }^{55}$ Auckland City Art Gallery' Quarterly, no. 10, 1959, p. 7.
} 


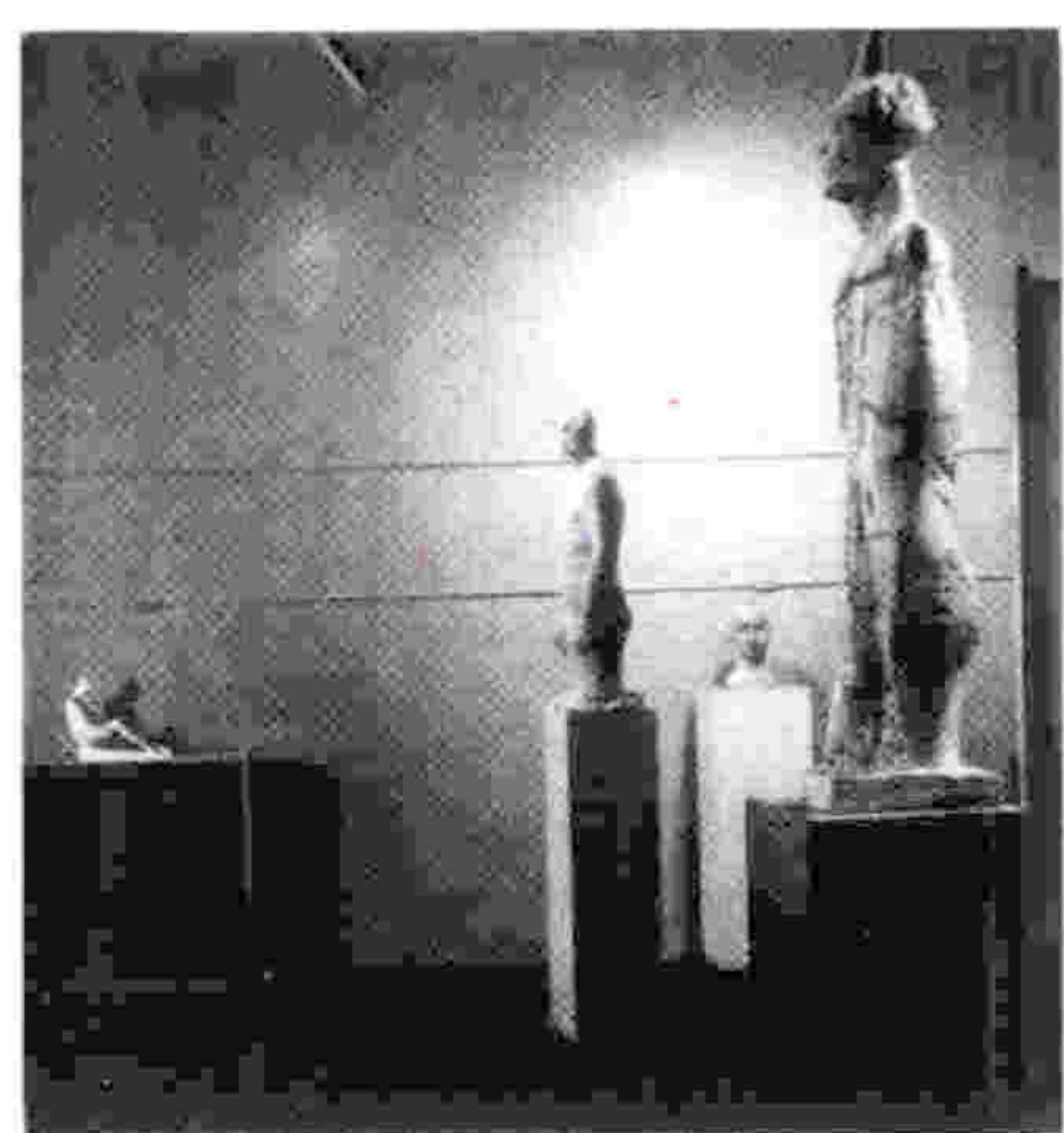

THE FIRST FLOOR GALLERY

The First Floor Gallery was redecorated at the beginning of this year and opened in February with an exhibition of paintings from five private collections. The ofd stage and dado have been removed and the addition of two screens makes hanging space available for about thirty paintings. The position, lighting and size of this gallery make it ideal for small exhibitions and a series of these have been arranged for 1959. So far, six exhibitions of paintings, sculpture and prints have been shown and five more are planned for the remainder of the year.

With the geographical isolation of the principal centres in New Zealand it is difficult for those interested in painting to obtain any complete idea as to what serious painting is being done throughout the country. Although occa-

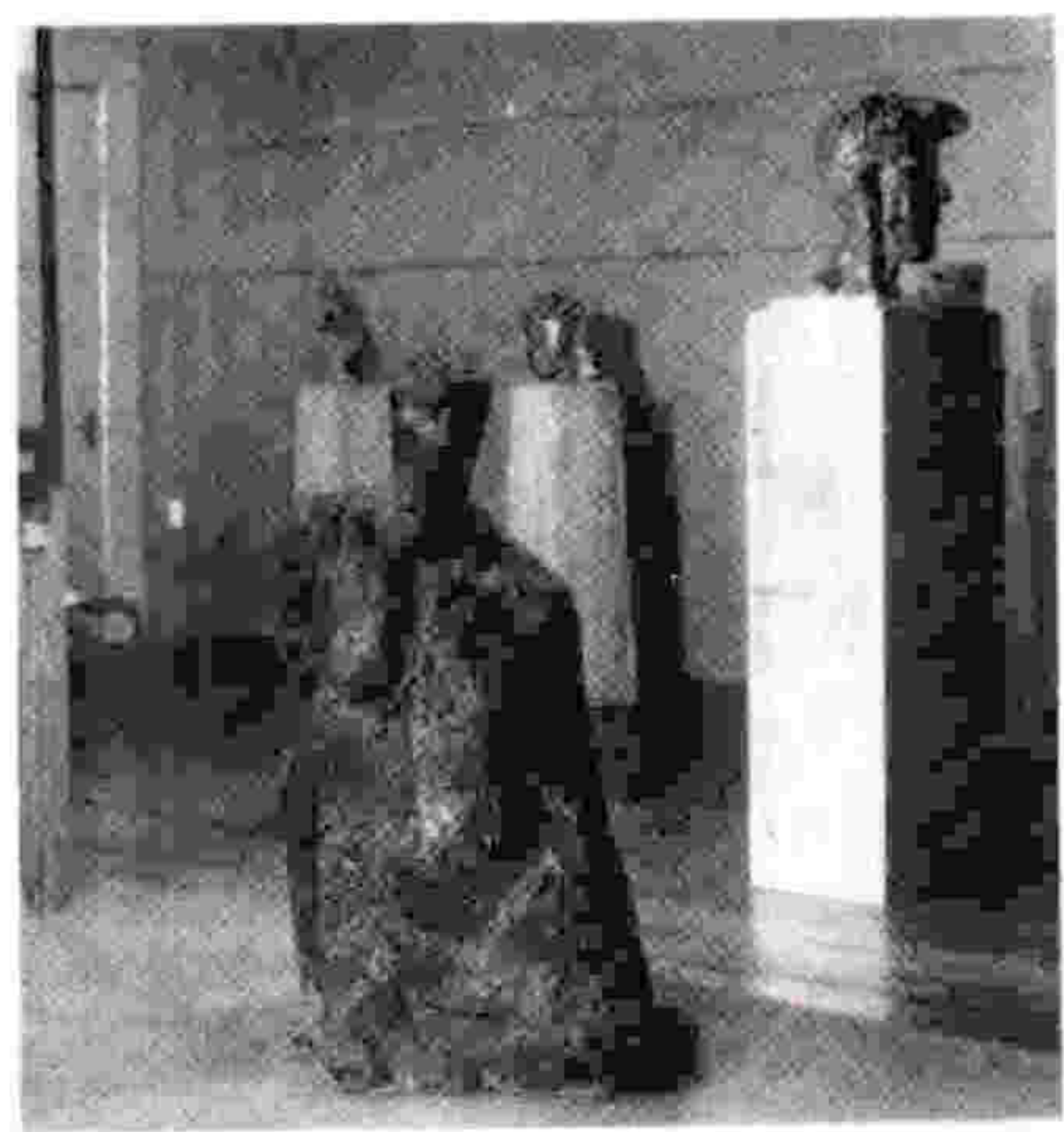

sional exhibitions of painting from other towns and the annual Eight New Zealand Painters Exhibition partially fill this gap, it is felt that they are not sufficient to supply a satisfactory survey. The object of this series is to present a continuous cxhibition of contemporary New Zealand art.

The exhibitions up to July have included two groups of painters from Wellington, two from Auckland, three Auckland sculptors and a collection of New Zealand prints. Further exhibitions will include paintings, pottery and sculpture from Christchurch, Wellington and Auckland.

A selective exhibition which will represent most painters who have exhibited during the year and introduce some new painters is being arranged for December.
Always scrupulous and deliberate, Gilman built up over the years an individual style at which he laboured to give it qualities of permanence and dignity. Though he manipulates broad planes, rich mosaics of colour, with much concem for their abstract qualities he is never unconcerned with the human element in his pictures; almost basically he aims to seize the essence or character of a portion of life and convey it in all subtlety to his canvas.

page seven

A page from the Auckland City Art Gallery Quarterly, no. 10, 1959, showing an installation view of an exhibition of contemporary New Zealand sculpture in the first floor gallery. As noted in the article, this show is one of a series instituted in the late 1950s designed to give contemporary New Zealand art more prominence in the Gallery exhibition programme. 
necessary supplement to the Eight New Zealand painters series and the existing programme of New Zealand painting exhibitions indicates the importance placed on showing a range of contemporary practice at the Gallery in this period. The shows also provided a crucial exhibiting opportunity for artists in the years between the closure of Peter Webb's gallery in 1958 and the opening of The Gallery on Symonds Street in 1960. As Tomory himself noted, the shows 'helped to keep New Zealand arts before the New Zealand public and make them familiar with serious artists throughout the Dominion. ${ }^{56}$ While the Gallery did not directly facilitate the sale of the works, increased sales of exhibiting artists' work were noted-again, the Gallery provided a stopgap between dealer facilities. ${ }^{57}$

Tomory's early attitude towards New Zealand art in both his collection and exhibition policies indicates a certain level of diffidence. Yet despite his repeated statement early in his tenure that the Gallery's key objective was the education of its audience rather than the promotion of the local artist, as the years passed the number of shows devoted to New Zealand work far outstripped his original suggestion of one survey exhibition each year. In November 1964 he told the New Zealand Herald that in the previous three years 98 New Zealand artists had been shown at the Gallery. Tomory's statements in this article seem to indicate that he came to a gradual realisation that the Gallery had to provide for New Zealand artists:

Mr Tomory said that in the year following an exhibition of New Zealand painting in 1959-60, five of the artists represented got on a ship to Europe. Whether this was the result of the exhibition he did not know, but it had been disconcerting to watch the artistic population fading out.

\footnotetext{
${ }^{56}$ Peter Tomory, 'Difficult year for Gallery', NZH, 12 December 1959, p. 26.

${ }^{57} \mathrm{Ibid}$.
} 
'So I went around New Zealand with the idea of showing in the next exhibition what was going on, and dealing with the younger artists if they were painting seriously. ${ }^{\prime 58}$

Tomory here gives the reason why the Gallery, after three instalments of the Eight New Zealand painters exhibitions, changed tack in 1960 and initiated the Contemporary New Zealand painting and sculpture series. Eight New Zealand painters was a series of annual touring shows designed to bring developments in New Zealand painting to the widest possible audience..$^{59}$ The exhibitions were essentially retrospective, encompassing an assortment of artists, ranging from long-standing favourites such as Russell Clark to the relatively avant-garde Don Peebles. In the catalogue for the inaugural show, Tomory wrote:

In New Zealand, with its principal towns geographically isolated, it is very difficult for those interested in painting to obtain any complete idea as to what serious painting is being done throughout the country.

Although several of the Art Societies open their annual exhibitions to painters from other towns, none of these provide a satisfying survey.

It was these thoughts that suggested this exhibition, which we hope to repeat each year.

We have tried to make the exhibition a reasonably representative one. There are men and women, from the South and from the North, some established artists, others not so established, representational painters and non-representational, and so on. ${ }^{60}$

Tomory concluded by stating that the link between the eight artists was that they were all 'serious painters'. This statement seems to constitute the selection criterion for the show, as there were few stylistic connections between the eight

\footnotetext{
${ }^{58}$ 'Tomory denounces talk of Gallery clique', $N Z H, 25$ November 1964, p. 2.

${ }^{59}$ The eight artists in the first show of the series were Rita Angus, Ivy Fife, John Holmwood, Milan Mrkusich, Michael Nicholson, William Sutton, Sydney L. Thompson and Dennis Knight Turner, each represented by five works.

${ }^{60}$ Peter Tomory, 'Introduction' in Eight New Zealand painters, Auckland: Auckland City Art Gallery, 1957.
} 
painters-Sydney Lough Thompson's impressionism, for example, Mrkusich's abstraction and Angus' regionalism were all featured in the first show.

The use of the word 'serious' allowed Tomory to group these disparate artists. Maria Brown proposes that by 'serious' Tomory meant artists who 'saw their art as their most important occupation and would have pursued it as a career had the option existed', and suggests that Tomory might have preferred to use the word 'professional', a term which was at that time inapplicable as artists could not earn a living from the sale of their work. ${ }^{61}$ Tomory's use of the term 'serious painting' should also be considered in the wider context of his New Zealand writing. In 'Looking at art in New Zealand' and in his contribution to Distance looks our way, Tomory distinguished 'serious' from 'popular' art, arguing that serious art works are produced by way of an emotional and intellectual engagement with the subject that popular or illustrative works - which simply re-present the familiar and rely upon the audience's recognition of a certain scene or subject-lack. Interestingly, Tomory separated the 'serious' from the 'professional' artist. He identified Hoyte and Gully as the first 'professional' artists, catering to a market of nostalgic recent immigrants: 'the professional artist - here I would distinguish him from the serious artist - soon succumbs to the repetitive production of popular devotional images, either nostalgic or superscenic.' ${ }^{62}$ Tomory's use of the term 'serious' could thus encompass artists of all styles, from neo-romanticism to abstraction, provided that he saw within their work an originality of approach.

Maria Brown concedes that the diversity of styles in the Eight New Zealand painters series 'may indicate that the gallery was prepared to mount representative shows even though some of the works did not fit the nationalist

\footnotetext{
${ }^{61}$ Brown, 'The history and function of the Auckland City Art Gallery' (1999), p. 112.

${ }^{62}$ Tomory, Distance (1961), p. 68.
} 
agenda. ${ }^{\prime 63}$ However, when the scope of the Gallery's exhibition programme at this time is considered, it is difficult to support the notion that artists were usually shown only if they were felt to represent Nationalist ideals. While the Gallery did not actively promote abstract artists in the same way that it promoted those artists, especially McCahon, Woollaston and Angus, who produced work related to the New Zealand landscape (the catalogues that accompanied the exhibitions of New Zealand art, for example, rarely mention or attempt to interpret abstract art) the point of these shows was to present a range of styles, rather than build support for one particular style. I.V. Porsolt, for example, reviewing Eight New Zealand painters III, commented on the exhibition's stylistic diversity. While noting in particular the range of abstract works, from Simmonds' cubist-influenced skyscapes to Jackson's tachiste-inspired works to Peeble's expressive abstract paintings, in the exhibition, Porsolt also remarked on the inclusion of more traditional artists, such as Russell Clark and Evelyn Page. ${ }^{54}$ Some contemporary reviewers took issue with the selection of artists for the series; H.M., reviewer for the Auckland Star, for example, declared that the majority of the painters in Eight New Zealand painters III had exhibited in the earlier shows and asserted that this was 'difficult to understand because there are equally good and, in an instance or so, better artists in Auckland alone who have not been given the chance to show their works in the gallery. ${ }^{65}$ Interestingly, given the accusations of 'benedictions', no artists were shown more than once, and McCahon (surely the most likely to be singled out for this kind of attention) was not included until the final show. As revealed by the cessation of the solo

\footnotetext{
${ }^{63}$ Brown, 'The history and function of the Auckland City Art Gallery' (1999), p. 160.

${ }^{64}$ I.V. Porsolt, 'Eight artists seen in group show', NZH, 19 October 1959, p. 15. Eight New Zealand painters III included Don Peebles, Evelyn Page, Freda Simmonds, Russell Clark, Keith Patterson, Alwyn Lasenby, Kase Jackson and Colin McCahon.

${ }^{65}$ H.M., 'Other N.Z. artists deserve place in exhibition', Star, 19 October 1959, p. 6. Hereafter abbreviated as H.M., 'Other N.Z. artists deserve place in exhibition' (1959).
} 
shows initiated by Westbrook, staff at the Gallery were very conscious of the risk they ran of being perceived as 'playing favourites', and the need for the Gallery to be seen as being above this kind of behaviour if the public were to believe their pronouncements about the value of art, both historical and modern. ${ }^{66}$

Gordon H. Brown has suggested that these criticisms prompted the rewording of the catalogue for Eight New Zealand painters II (1958-59).$^{67}$ Here Tomory noted that, as with the first show, the second aimed at 'a cross section of serious painting in the Dominion.' ${ }^{68}$ He was careful to avoid any suggestion of special favour: 'We have made no attempt to select in order of merit but rather to present together artists who are making a positive contribution to the art of painting in New Zealand.' 69 The introduction for the third and final show in the series was terse: 'This is the last exhibition of this series. Like those before, it aims to represent serious painting in New Zealand. Again, we have endeavored to show works by established artists and also those of a younger generation. ${ }^{70}$ Aligned with the Eight New Zealand painters exhibitions is the 1958 exhibition Five New Zealand watercolourists. ${ }^{71}$ Gordon H. Brown sees this exhibition as more 'artistically consistent' than the other three, agreeing with Tomory's reasoning that watercolour painting was more advanced in New Zealand than oil painting, due to the length of the watercolour tradition, which stretched back to the topographical artists. ${ }^{72}$ Nevertheless, Eight New Zealand

\footnotetext{
${ }^{66}$ Hamish Keith, personal communication to the author, 9 February 2004.

${ }^{67}$ Brown, New Zealand painting 1940-1960 (1981), p. 56.

${ }^{6}$ Peter Tomory, 'Introduction' in Eight New Zealand painters II, Auckland: Auckland City Art Gallery, 1958. The eight painters were Doris Lusk, Jan Michels, Janet Paul, Ron Stenberg, Arthur Thompson, John Weeks, Toss Woollaston and John Zambelis.

69 Ibid.

${ }^{70}$ Peter Tomory, 'Introduction' in Eight New Zealand painters III, Auckland: Auckland City Art Gallery, 1959.

$"$ Five New Zealand watercolourists included Rita Angus, Olivia Spencer Bower, T.A. McCormack, Gabrielle Hope and Eric Lee-Johnson

${ }^{72}$ Brown, New Zealand painting 1940-1960 (1981), p. 56; Peter Tomory 'Introduction'. Five New Zealand watercolourists, Auckland: Auckland City Art Gallery, 1958.
} 
painters III indicated the development of a school based around McCahon, the Gallery and its Summer Schools. The show included McCahon and two of his students, Freda Simmonds and Alwyn Lasenby; the similarity between their work was noted by Christchurch artist and reviewer Nelson Kenny, who described Lasenby as 'a new painter of more than usual talent', but saw Simmonds' work as derivative and 'crude' in comparison. ${ }^{73}$ The similarity was also noted by H.M., who praised Kase Jackson for not conforming to 'the present imitative fashion of contrasting whites and blacks with a touch or so of green and red that is over-present in the show. ${ }^{74}$ As Gordon H. Brown has observed, while some of the criticism levelled at the series was justified, the shows taken as a whole did have some effect on 'whittling down parochial attitudes and preference for local painters. ${ }^{.75}$

In 1960 the Eight New Zealand painters series expanded into a series of more general exhibitions, Contemporary New Zealand painting and sculpture, held annually until 1966. The new objective was to present recent (less than two years old) work from a wider range of artists. The series aimed for coverage of 'serious painting' which reflected a 'cross-section of contemporary work' by both established and younger artists, and demonstrated 'artistic activities in other centres beside Auckland. ${ }^{76}$ The feeling at the time was that these shows marked an important moment in New Zealand painting. McCahon, writing to Ron O'Reilly, noted that the 1960 exhibition Contemporary Australian art was a flop, but 'rightly so', as it 'followed immediately on our N.Z contemporary ex. and

\footnotetext{
${ }^{73}$ Nelson Kenny, 'Last show in 'Eight New Zealand painters' series the best', Press, 23 June 1960, p. 17.

${ }^{74}$ H.M., 'Other N.Z. artists deserve place in exhibition' (1959).

${ }^{75}$ Gordon H. Brown, New Zealand painting 1940-1960 (1981), p. 57.

${ }^{76}$ Peter Tomory, 'Foreword' in Contemporany New' Zealand painting 1963, Auckland: Auckland City Art Gallery, 1963. Similar wording is used in all the brief forewords Tomory wrote for the catalogues in this series.
} 
just didn't measure up. ${ }^{77}$ Contemporary New Zealand painting and sculpture, McCahon continued, marked 'the first time some real pride and enthusiasm seemed to develop about N.Z. painting. ${ }^{78}$ Nelson Kenny, reviewing the first exhibition for the Press, described it as one of the best shows ever assembled by the Gallery, with the general level of painting being 'surprisingly high' and 'not inferior' to that of exhibitions of international art the Gallery had recently toured. ${ }^{79}$ Kenny also noted that an 'indigenous style of painting' could be detected, and pointed to McCahon's influence:

The general character of the exhibition shows a tendency towards airy, spacious compositions with rather light, high-keyed colour. Several of the Aucklanders work in a style composed of simple forms and brilliant effects of light, but it owes so much to the individual example of Colin McCahon that it cannot be classed as a regional style. ${ }^{80}$

For Brown and Keith, looking back in the late 1960s, it was the 1962 exhibition that marked the point at which a New Zealand style began to reveal itself. ${ }^{81}$ Keith also reviewed this show in 1962, at which time he saw a 'much greater conviction [and] a much more general commitment to painting as a means of communicating ideas' ${ }^{82}$ Keith identified a number of changes that suggested to him that New Zealand's painters and sculptors were maturing. Although Europe, he declared, could still be seen in some works (especially those by Melvin Day and Paul Olds), in other works 'the elements that have always been present in and unique to the best New Zealand painting have become more

\footnotetext{
${ }^{77}$ Colin McCahon, letter to Ron O'Reilly, 22 June 1960, AAG archives.

${ }^{78}$ Ibid.

${ }^{79}$ Nelson Kenny, 'Woollaston dominates N.Z. painting exhibition', Press, 22 July 1960, p. 5. The 1960 exhibition was shown at the Robert McDougall Art Gallery without the sculpture section.

${ }^{80}$ Ibid.

${ }^{81}$ Brown and Keith. Introduction (1969), p. 175.

${ }^{82}$ Hamish Keith, 'Contemporary New Zealand painting and sculpture', Home and Building, vol. 25, no. 7 , December 1962, p. 49.
} 
obvious and controlled. ${ }^{83}$ Keith also detected an increased amount of passion in the work ('[more] than was previously considered desirable or decent') and stated that artists had started to worry less about garnering approval in its various manifestations, such as having work reproduced in Landfall, or being toured by the Canterbury Art Society. ${ }^{84}$ Joining in Tomory's criticism of literary critics and literary-influenced painters, Keith noted that the most remarkable change in recent New Zealand painting was 'its emancipation from the rather literary directions imposed on it by the pressures to produce a national style. ${ }^{\prime 85}$ Keith discerned a new interest in the urban landscape and in people, and - while noting that McCahon and Woollaston continued to lead as New Zealand's most mature and accomplished artists, and that landscape was still the dominant subject matter-he pointed to Bryan Dew, Tim Garrity and Nelson Kenny as examples of a new generation of artists more interested in human relationships or urban situations.

Gordon H. Brown, writing in 1978, observed that the introduction of survey shows of contemporary New Zealand art marked a change in Tomory's attitude towards New Zealand art. In his analysis Brown added to these survey shows 'exploratory exhibitions' such as Painting from the Pacific and $A$ retrospective exhibition: M.T. Woollaston and Colin McCahon, and notes that these exhibitions were as important for artists as they were for gallery-goers:

The combined effect of these exhibitions gave the viewer the chance to clarify and expand his responses to the visual arts as well as to define more clearly the dimensions of New Zealand's art. To the artist especially they supplied points of reference against which could be measured his own achievements. ${ }^{86}$

\footnotetext{
${ }^{83}$ Ibid.

84 Ibid.

85 Ibid.

${ }^{86}$ Brown, 'The visual arts' (1978), p. 326.
} 
In addition to the exhibitions devoted to contemporary practice, the Gallery also organised shows of historical New Zealand art, with the intention of creating a historical context for New Zealand art. A reporter writing in the Auckland Star in 1965, summarising Tomory's achievements at the Gallery, noted that:

In exhibitions of New Zealand painting there has been as much concentration on early as contemporary art, the endeavour being to show the continuity of New Zealand painting.

A painter of about 1890, Van der Velden, is regarded by Tomory as the father of modern painting in our country. A realist, he brought a sense of tension and other underlying feeling into his painting. Not only have his works been frequently exhibited, but the gallery's own examples of his work have been increased from two to a dozen.

He is but one of several other painters of the past whom the gallery has brought into deserved prominence. ${ }^{8.7}$

Van der Velden was given a prominent place in Tomory's New Zealand art history, his importance being a matter of both the stylistic influence he exerted and the professional example that he set for New Zealand artists. Other artists were also accorded solo exhibitions with accompanying catalogues, including J.C. Hoyte, James Crowe Richmond, John Kinder and James Preston. While the catalogues for the contemporary exhibitions usually consisted of a list of the works framed by a few introductory remarks, the catalogues for the historical artists form some of the first pieces of monographic scholarship on New Zealand artists. In addition to these monographic shows several group exhibitions were organised, including A colonial view: paintings of early New Zealand in 1958 and Colonial Auckland: a collection of paintings, drawings and prints by early artists in 1959.

\footnotetext{
${ }^{87}$ Mac Vincent, 'The Aucklander's Diary', Star, 6 January 1965, p. 6.
} 


\section{AUCKLAND CITY ART GALLERY}
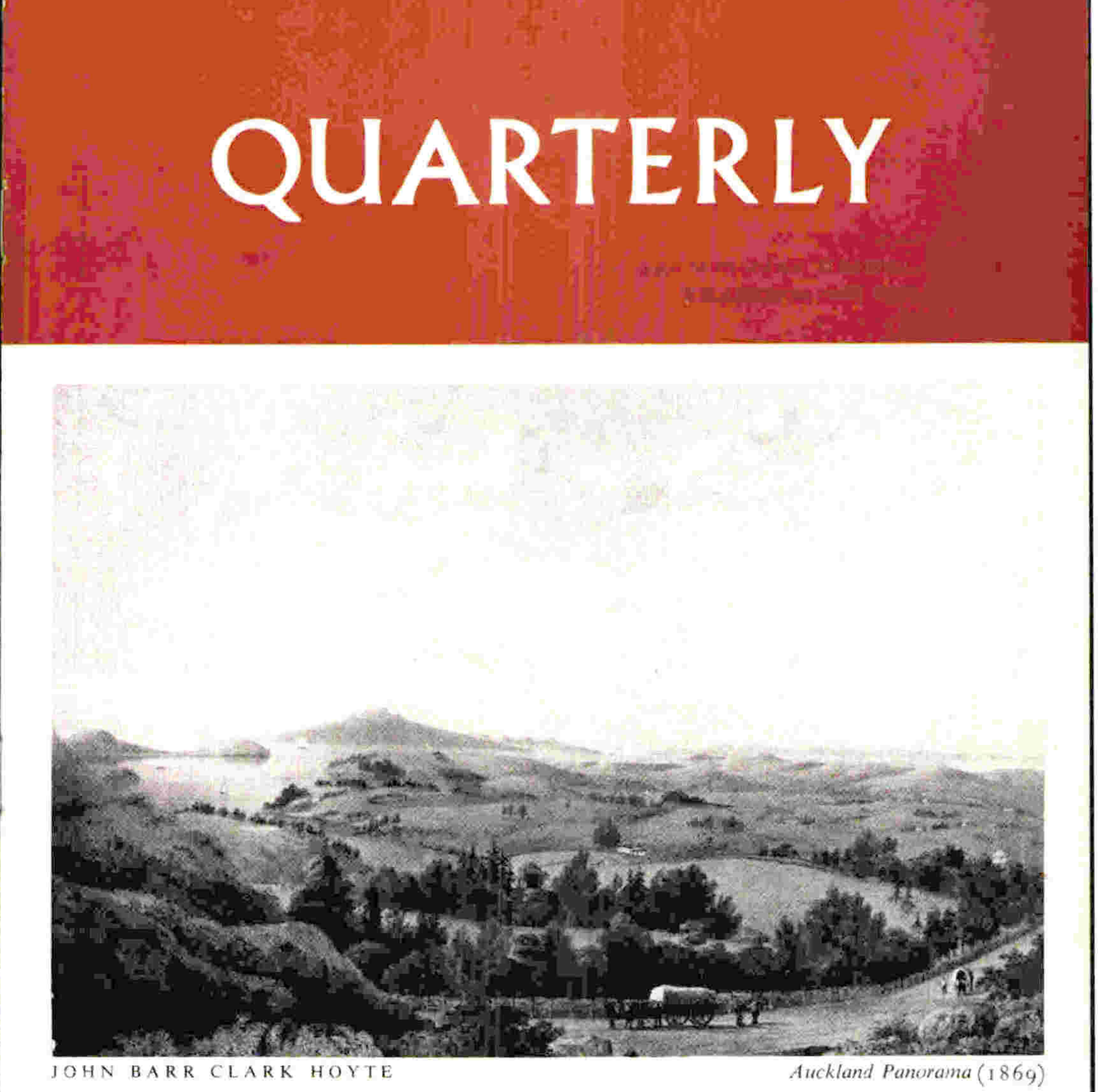

Cover of the Auckland City Art Gallery Quarterly, no. 3, 1957, with a reproduction of J.C. Hoyte's watercolour An Auckland panorama, 1869, gifted to the Gallery in 1936 by Mrs Jessie Williamson. An article in the Quarterly announces a show of Hoyte's work, one of a series of exhibitions devoted to the work of early New Zealand artists. 
As noted above, these exhibitions were intended to establish a historical context for contemporary New Zealand art. Brown and Keith see the decision during Westbrook's tenure to create a collection of Frances Hodgkins' work and to ask Eric McCormick to organise the 1954 exhibition Frances Hodgkins and her circle as the beginnings of the 'tentative construction of a general context for native art' ${ }^{88}$ A number of other exhibitions of early New Zealand artists, accompanied by catalogues, were organised under Westbrook. Brown and Keith also observe that McCahon had joined the Gallery staff at about the same time as this project was set in motion, and remark that 'it is, perhaps, not without significance that a painter of the comparatively radical present became directly involved with the presentation of a newly discovered past. ${ }^{\prime 89}$

In The New Zealand realist tradition (1960) comparisons were explicitly drawn between past and present New Zealand artists. In this show 19th- and 20th-century works were linked for the first time on a stylistic basis; Kinder, Sharpe and Hoyte with Angus and Doris Lusk; van der Velden with Woollaston; Frank and Walter Wright with Sutton and Russell Clark. If the exhibitions of contemporary art were relatively diverse stylistically, the exhibitions of historical New Zealand art tended to focus on those artists who were seen to be working in a style that had direct links to modern painting. As Maria Brown notes, in this way artists such as Kinder and John Buchanan, previously seen as producers of historical or topographical records, were now re-framed as predecessors in a recognizably New Zealand style. ${ }^{90}$ Hamish Keith, looking back on the period, sees these historical exhibitions as a vital undertaking, both in establishing a

\footnotetext{
${ }^{88}$ Brown and Keith, Introduction (1969). p. 167.

${ }^{89}$ Ibid.

${ }^{90}$ Maria Brown, 'The public art gallery and the construction of a canon of modernist New Zealand art', paper presented at the conference of the Art Association of Australia and New Zealand, Victoria University of Wellington, 2-5 December 1999, published as Pre/dictions: the role of art at the end of the millennium, p. 144.
} 
context for New Zealand art, and also for the confidence of artists, who 'now felt they were not cut off, [that] there had been people here before them.' ${ }^{91}$

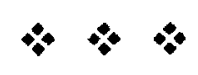

The criticism most often levelled at the Gallery's exhibition policy (and therefore at Tomory and other Gallery staff, namely Keith and Brown) by post-nationalist critics is that exhibitions of New Zealand art at this time served largely to construct a canon of New Zealand artists approved by nationalist writers; a canon of painters who responded to the supposedly unique character of the New Zealand landscape and the New Zealand light. One of the loudest voices in this critique is that of art historian Francis Pound, who has argued that between 1930 and 1970 the majority of commentators on the visual arts showed an intense and continuous aversion towards abstract art and artists. In a recent article on Gordon Walters Pound writes that:

it should be recalled that from 1930 through to the '70s and beyond there was an intense rhetoric against abstraction. The poet and critic A.R.D. Fairburn perfectly set the tone for much Nationalist criticism to come when he wrote in 1931: 'As soon as you abstract, you falsify, and give the lie to life. Hence the stinking falseness of all abstract art, that is to say all analytic art. Hence the death-corpse-stinking falseness and utter dishonesty of Picasso ... Picasso is a bearer of still-born children. ${ }^{\prime 92}$

Pound argues that artists who did not fit the Nationalist model-especially artists producing purely abstract work - were often 'condemned during the

\footnotetext{
${ }^{91}$ Hamish Keith, personal communication to the author, 9 February 2004.

${ }^{92}$ Francis Pound, 'A memory inhering in forms: new sources in the later paintings of Gordon Walters,' Art New Zealand 107, Winter 2003, fn. 8, p. 90. The quotation is from a letter from Fairburn to Clifton Firth, 23 December 1931; see Edmond (ed.), The letters of A.R.D. Fairburn (1981), pp. 60-61.
} 
Nationalist time to relative silence and invisibility'. ${ }^{93}$ He also argues that supporting abstract artists - artists working in an 'Internationalist' style - would have run counter to the nationalist ideology and the endeavour to identify an indigenous art, which, it was thought, would grow from the interpretation of New Zealand. As he wrote in 1989:

Any too pure a Modernism was seen in New Zealand specifically as a departure from landscape-and usually a reprehensible departure. A Nationalist criticism constituted as pathological all possibility but landscape. It soon pathologised painters like Mrkusich and Walters as the 'foreign', as the 'Internationalist', as the reprehensible Other. ${ }^{94}$

In the 1980 s post-nationalist writers sought to 'de-pathologise' abstract artists, and assert their existence (and significance) during the nationalist period. Gordon Walters in particular became the key example of an abstract artist overlooked by nationalist taste-makers. Maria Brown writes; 'if the records and publications of the Auckland City Art Gallery were all that survived from the period 1952 to 1964 one might conclude, wrongly, that [Walters] was not active as a painter in that period. ${ }^{\prime 95}$ Brown then seeks to explain why Tomory did not write about Walters, and why his work was not exhibited or collected by the Auckland Gallery:

Walters' total commitment to abstraction may have played a part but Mrkusich and Peebles, who also painted in an abstract manner, exhibited frequently at the gallery and both were represented in exhibitions sent overseas. The fact that Walters was based in Wellington could be a factor, but so was Peebles who, like Walters, had spent several years out of New Zealand. There was also Walters' recourse to Maori motifs which was not

\footnotetext{
${ }^{93}$ Francis Pound, 'The word and the art: New Zealand art criticism c. 1950-c. 1990' in Mary Barr (ed.), Headlands: thinking through New Zealand art, Sydney: Museum of Contemporary Art, 1992, p. 187. Hereafter abbreviated as Pound, Headlands (1992).

${ }^{74}$ Francis Pound, 'Walters and the canon', in James Ross and Laurence Simmons (eds.), Gordon Walters. order and intuition, Auckland: Pelorus Print, 1989, p. 55. Pound's emphasis. Hereafter abbreviated as Pound, 'Walters and the canon' (1989).

${ }^{95}$ Brown. 'The history and function of the Auckland City Art Gallery' (1999), p. 179.
} 
easily accepted, but then at least one painting by Theo Schoon, evidently based on Maori art, was shown at the Auckland City Art Gallery. ... Additionally, Paratene Matchitt and Arnold Wilson, two Maori modernists, also exhibited at the Auckland City Art Gallery. Perhaps the main factor was the fact that Walters did not exhibit until 1965, therefore, very few people must have been aware of his work and its quality. ${ }^{96}$

In his essay 'Walters and the canon' Pound quotes Walters' avowal that he did not show his 1950 s abstract gouaches for nearly two decades because he considered the artistic climate previously to have been hostile to abstraction, and then states:

Walters' consideration was right, of course. The Nationalist climate was hostile to abstraction. ... This, I would say, was the largest solitude in New Zealand, the solitude of painters like Walters, the solitude of what was called the 'ultra modernist'-and not that much vaunted and mythical solitude of McCahon ... ${ }^{97}$

Pound concludes with a rhetorical flourish: 'Will it perhaps be the fate of my text to announce such a myth for Walters? A myth of suffering solitude? To become, in this respect, an unwished for, but perhaps not entirely undesirable, annunciatory angel?'98 The short answer would be 'yes'. As Nicholas Thomas has declared, 'the art-historical tale that has been told [about Walters' marginalization] is sheer myth'.99 As Maria Brown concludes, it is very difficult to show an artist who is not making his work available for public exhibition.

Once Walters began showing, he was quickly absorbed into the artistic mainstream, with exhibition opportunities, positive reviews and government

\footnotetext{
Thid.

${ }^{97}$ Pound, 'Walters and the canon' (1989), p. 59. Pound's emphasis.

98 Ibid.

${ }^{99}$ Nicholas Thomas, Possession. indigenous art/colonial culture, London: Thames and Hudson, 1999, p. 145.
} 
grants, including an Arts Council Fellowship in 1971. Nicholas Thomas notes:

From the time he began to exhibit his mature work in the mid-1960s, Walters was never marginalized or stigmatised to the extent that has been asserted. His isolation has been stressed in order to build an image of a creative figure far ahead of an indifferent and mediocre culture. ${ }^{100}$

Writing by post-nationalist critics, intent on reinserting abstract artists into the art history of the 1950s and 1960s, has served to create an impression of an artistic culture far more hostile to abstraction than actually seems to have been the case. It is difficult, for example, to support the notion of Mrkusich as 'pathologised' in the nationalist period when one looks over the exhibition records from the time. Admittedly, Mrkusich was not accorded anywhere near the critical attention received by McCahon, Woollaston and Angus. However, during Tomory's tenure Mrkusich was included in a wide range of exhibitions, including Eight New Zealand painters (1957), Contemporary New Zealand painting and sculpture (1960), Three New Zealand painters: Milan Mrkusich, Don Peebles, J.P. Snadden (1960), Contemporary New Zealand painting (1961), Painting from the Pacific (1961) and Contemporary painting in New Zealand, the 1964 exhibition curated by Tomory for the Arts Council and shown at the Commonwealth Institute in London. It is significant that Mrkusich was included in a number of survey shows, in particular Painting from the Pacific and Contemporary painting in New Zealand, where his work was intended to represent an abstract movement in New Zealand painting. While no purchases were made of Mrkusich's work during Tomory's tenure, his Landscape (1955) had been purchased in 1955, Painting 61-13 (1961) was purchased in 1965 and Four elements above (Crimson) (1965) in 1966.

Richard Lummis, in his thesis on Dennis Knight Turner, makes a similar point, arguing that Turner's work was shown regularly at the Gallery as part of 
Tomory's attempt to reconcile viewers to modern New Zealand art. ${ }^{101}$ Lummis rebuts Robert Taylor's characterisation of Turner's work as marginalised, disregarded and excluded, including his statement that:

As the support structures for the future professionalism of New Zealand art began shaping, it became increasingly clear that efforts were to be orchestrated around particular individuals, and that these did not include the untrained commercial upstart from Wanganui. ${ }^{102}$

Lummis cites Turner's shows at the Gallery - such as his inclusion in New Zealand painting (1956), Eight New Zealand painters (1957) Contemporary New Zealand painting and sculpture (1962) and Contemporary New Zealand painting (1963) - as evidence against this statement. Turner himself does not appear to have felt slighted by the Gallery, and to have respected the judgement of the Gallery staff, as this 1957 letter to Tomory suggests:

The prospects of the exhibition [Eight New Zealand painters] are intriguing, and important for the painters concerned, and I am pleased therefore that I should not myself have to select my exhibits. I experiment too much to know for sure if any of it is good..$^{103}$

Don Peebles' work was also frequently presented at the Gallery from the late 1950 s. His work from the very end of the 1950s shows an increased mastery of colour and composition; these completely abstract paintings received positive reviews in Wellington and, as Justin Paton notes, 'lifted Peebles onto a regular (or less irregular, at least) exhibition circuit, chiefly at the Auckland City Art Gallery, whose progressive new director Peter Tomory had arrived at the Gallery

\footnotetext{
${ }^{100}$ Ibid.

191 Richard Lummis, 'Denn1s Turner in context', unpublished MA thesis, University of Auckland, 1998, p.

10. Here after abbreviated as Lummis, 'Dennis Turner in context' (1998).

${ }^{102}$ Robert Taylor. 'Tiki: the return of Dennis Knight Turner', Art New Zealand 67, Winter 1993, pp. 58-62, p. 59.

${ }^{103}$ Dennis Knight Turner, letter to Peter Tomory, 16 January 1957, AAG archives.
} 
in 1956 and ushered several Wellington abstractionists northwards. ${ }^{\prime 104}$ Granted an Association of New Zealand Arts Societies Fellowship Award in 1960 (the first abstract painter to receive one of the very few grants available to artists at this time, itself an indication that institutions were not as averse to abstract art as has been argued) Peebles lived in London from 1960 to 1962. Despite this absence, his work was shown at regularly at the Gallery between 1959 and 1964, including the important exhibitions Painting from the Pacific and Contemporary painting in New Zealand (1964).

In 1961 the Gallery staged Painting from the Pacific, an exhibition which brought together New Zealand, Australian, Japanese and West Coast American painters. By showing New Zealand artists with artists from other countries, the show significantly extended the comparative activities undertaken in earlier shows, such as The New Zealand realist tradition in the previous year. Painting from the Pacific was an experiment designed to test the hypothesis that painting in countries bordering the Pacific had developed common stylistic features. The impetus for the exhibition came from McCahon's 1958 trip to the United States; upon his return $\mathrm{McC}$ ahon spoke of his curiosity as to whether the art produced in countries bordering on the Pacific might share any similar elements. ${ }^{105}$ Tomory, writing in the introduction to the catalogue, noted that in recent exhibitions of West Coast American, Japanese and Australian art at the Gallery similarities had been observed between artists from those countries and artists from New Zealand - a similarity Tomory described as a 'a certain

\footnotetext{
${ }^{104}$ Paton, Don Peebles (1996), p. 16.

${ }^{105}$ Gordon H. Brown, personal communication to the author, 19 January 2004.
} 
homogeneity - a sympathetic link, perhaps intangible, and certainly indefinable.' The point of the exhibition was to bring painting from the four countries together in order to test the hypothesis that the Pacific 'provided some common characteristic: perhaps light, or topography, or perhaps again, some indefinable element.' 106 Tomory's introduction had a distinctly speculative tone, and emphasised that whether or not the hypothesis was proved, the show would nonetheless 'give considerable evidence of the vitality of contemporary painting in the Pacific.'107

Tomory's introduction to the New Zealand section of the catalogue cast New Zealand painting - and the exhibition - in regional terms. He wrote:

\begin{abstract}
All four regions have a coastline with thousands of square miles of the Pacific hemmed against it. This huge liquid mirror reflects back the light, giving it an intensity which exposes the natural forms in sharp contrasts of black and white: a phenomenon more true perhaps of the islands of Japan and New Zealand than of the Pacific coasts of America and Australia with their continental hinterlands.

The New Zealand paintings in the present exhibition have been chosen particularly because they demonstrate this regional attachment. For all ten artists, whether Europe, Japan or America have pointed their direction, have achieved what might be called successful regional adaptions - which subscribe to the general theme of this exhibition. ${ }^{108}$
\end{abstract}

Other contributors to the catalogue discussed the works in regional terms. Laurie Thomas, writing on the Australian exhibits, noted that 'None of the artists represented in this small and by no means comprehensive collection of Australian paintings would want to be insular in expression, but all would hope

\footnotetext{
${ }^{106}$ Peter Tomory, 'Foreword' in Painting from the Pacific, Auckland: Auckland City Art Gallery, 1961, n.p. ${ }^{107}$ Ibid.

108 Peter Tomory, 'New Zealand introduction' in Painting from the Pacific, Auckland: Auckland City Art Gallery, 1961, n.p.
} 
that something distinctively local would somehow reveal itself in their work. ${ }^{\prime 109}$ George Culler, writing on the American works and the idea that artistic movements had now become 'universal', suggested that 'important regional and individual differences exist within the shared idioms, the world-wide trends. Painting in the United States has some qualities other than those found in European work, and within the United States paintings created on the West Coast differ in significant ways from the productions of the New York school. ${ }^{\prime 110}$

The New Zealand artists included were John Holmwood, Jean Horsley, Alwyn Lasenby, McCahon, Mrkusich, Keith Patterson, Peebles, Freda Simmonds, John Pine Snadden and Woollaston, each represented by a single work. The loose grouping of Auckland painters who depicted the landscape in a semi-abstract manner, associated with McCahon and his Summer School classes, was heavily represented. The selection was however aimed at showing a range of stylistic response to the Pacific situation, and therefore included the romantic realism demonstrated by Holmwood, Woollaston's regional expressionism and the abstract painting of Mrkusich and Peebles. While these groupings meant that links could easily be drawn between the New Zealand painters, Tomory's general hypothesis proved incorrect. As Brown and Keith note: 'Some relationship could be made between the Japanese, West Coast American and New Zealand paintings in the collection, though almost none between them and the Australian group, but not to the extent that it could be said to derive from a specifically Pacific context.' ${ }^{111}$ For these commentators, the show was significant because for the first time contemporary New Zealand painting had been aligned

\footnotetext{
${ }^{109}$ Laurie Thomas, 'Introduction Australia' in Painting from the Pacific, Auckland: Auckland City Art Gallery, 1961, n.p.

${ }^{110}$ George Culler, 'America introduction' in Painting from the Pacific, Auckland: Auckland City Art Gallery, 1961, n.p.

${ }^{111}$ Brown and Keith, Introduction (1969), p. 165
} 
with its international counterpart. Brown and Keith's assessment was shared by contemporary commentators, including Tomory himself.

Tomory reviewed his own show in Home and Building. He described the exhibition's intent as 'ambitious', but acknowledged that 'one would be brave indeed to state that its aim was realised in any positive manner.' ${ }^{112}$ Tomory did identify one feature that all the paintings seemed to share:

there was one thing which seemed to have a regional quality and that was the brushwork. It is difficult to define but I remember in Dusseldorf seeing the David Thompson collection, in which nearly every well-known 20th century European artist was represented. The quality was prodigious but there was one room containing only American paintings-Guston, Motherwell, Rothko, Pollock, etc., and suddenly I was aware of feeling quite at home. Now the main difference was the putting on of the paint. It had a kind of blunt inelegance about it. ${ }^{113}$

Tomory acknowledged that this claim was tenuous, and that his suggestion was tentative and more applicable to the American, New Zealand and Australian works. For Tomory, unlike Brown and Keith, it was the Japanese work that did not fit the general pattern, an aberration he put down to a long tradition of craftsmanship leading to 'subtleties and refinements' not apparent in the other countries' exhibits. Another factor separating the Japanese works from the others, in Tomory's opinion, was the decorative role of painting in Japan, in comparison to the European attitude which 'eschews decoration as an aim.'114 Tomory noted that his reaction to the Japanese works was coloured by his Western art-historical perspective: 'we as European critics fail sometimes to

\footnotetext{
${ }_{112}^{112}$ Peter Tomory, 'Painting in the Pacific', Home and Building, vol. 24, no. 2, July 1961, p. 56.

${ }^{113}$ Ibid.

${ }^{114}$ Ibid., p. 59.
} 
accept decoration and try to extract something that was never there in the first place. ${ }^{115}$

Wystan Curnow also reviewed the exhibition, in Landfall, where he convincingly refuted the validity of Tomory's claims for geographical similarity. ${ }^{116}$ He did allow, however, one similarity that characterised the Pacific Rim region:

a common concern with the overbearing presence of the land and sea, an affinity which, by its very nature, leads to disparity since, in each region, the painter must come to grips with what are, I maintain, regional situations. ... And this is a concern which is certainly not shared by the metropolitan art centres of Europe and the American East Coast ... ${ }^{117}$

Curnow stated that metropolitan art was 'much more likely to produce a common set of symbols than is the art of the Pacific because highly urbanized, industrialized, nations tend to present the artist in any part of the globe with rather similar environmental tensions. ${ }^{118}$ Art from Pacific regions, Curnow argues, is less likely to share a common language, as artists in these regions respond to individual, regional, situations. Japan (highly industrialised and densely populated) would appear to contradict Curnow's argument, a contradiction he dealt to by noting the 'forbidding and menacing presence' of its mountainous landscape. Like Tomory, Curnow contrasted the refinement of the Japanese exhibits with the 'raw vitality' of the New Zealand, Australian and some of the American works.

Curnow saw the New Zealand selection as the only one to directly address the exhibition's thesis, feeling that the three other countries'

\footnotetext{
${ }^{115}$ Ibid.

${ }^{116}$ Wystan Curnow, 'Painting from the Pacific', Landfall, vol. 15, no. 3, September 1961, p. 259. Curnow's emphasis.

117 Ibid., p. 260.

${ }^{118}$ Ibid., p. 259.
} 
contributions were simply representative of painting in those regions in general.

Curnow, like Tomory, discussed the works in terms of regional styles:

New Zealand painters over the last decade or so have generally sought an effective regional definition and the works of Lasenby, Peebles and Woollaston demonstrate a growing maturity which is unmatched by the Australian exhibits. Mrkusich and McCahon share with these painters a power and honesty of conception that cannot be denied. McCahon once again gives proof of his ability to create symbols that possess a compulsive empathy in a work [Gate, 1961] which, interestingly enough, is compositionally akin to those of Bischoff and Diebenkorn. ${ }^{119}$

Painting in the Pacific was a highly significant, if flawed exhibition.

Although its premise was disproved, it stands as an early instance of contemporary New Zealand painting shown in an international context.

Moreover, it is significant because it placed the regional quality of New Zealand art-rather than a single, national style-in relation to that of other Pacific rim nations, denying New Zealand's and New Zealand art's supposed insularity. As the following extract from Tomory's 1985 interview with Kirker reveals-and as will be discussed in the following chapter-regionalism was a notion that enjoyed significant currency in this period:

We all had ideas about what constituted an indigenous way of painting, etc. At Auckland we organised that big show Art of the Pacific [sic] to see if there was some kind of common factor. In the end, I don't think there was one. That was very revealing because what you saw was contemporary art and each country had its own particular way of tackling it. Artists don't think of themselves as Australians or New Zealanders or Canadians, they think of themselves as artists - they are making art. ${ }^{120}$

\footnotetext{
$11{ }^{\circ}$ Ibid., p. 262.

${ }^{120}$ Kirker, Art New Zealand 41 (1986), p. 76
} 
Tomory saw the Gallery's core role as the 'raising and spreading of aesthetic standards amongst the public.' ${ }^{121}$ The development and display of the Gallery's permanent collection was one way of educating the audience. The programme of temporary exhibitions - intended to complement rather than outshine the exhibitions of collection works - was another. While initially Tomory advised that the Gallery should hold four or five exhibitions of oil paintings each year (brought in from overseas) and an annual exhibition of contemporary New Zealand painting, as this chapter has shown, the temporary exhibition programme expanded considerably beyond this original vision, especially as the Gallery became the leading facilitator for touring shows in New Zealand. Most notably, Tomory's exhibition programme did much to familiarise audiences in Auckland and throughout the country with modern art, both international and local. The Gallery also offered significant opportunities for contemporary New Zealand artists to show their work in a period when alternatives to the traditional art society shows were only just beginning to emerge. In 1968, in The pattern of New Zealand culture, Tomory noted that the regular stream of exhibitions that now moved around New Zealand had significantly contributed to a new level of 'public awareness and demand, resulting in the establishment of dealer galleries and thereby serious recognition for the New Zealand artist. ${ }^{\prime 122}$ In this way Tomory (four years after leaving the Gallery) confirmed that one of his major objectives as Director had been achieved.

\footnotetext{
${ }^{121}$ Tomory, 'Auckland City Art Gallery director's report April 1956', p. 6.

122 Tomory, Pattern (1968), pp. 203-4.
} 


\section{Peter Tomory and New Zealand art history}

Like Gaul, the history of art in New Zealand can be divided into three parts. The topographical period, the transitional period, and the modern period-a rather similar pattern to that which obtains in the United States, and a pattern which is to be found in almost all ex-colonial countries. ${ }^{\text {. }}$

During his twelve years in New Zealand, Tomory wrote prolifically, publishing articles on New Zealand art in a range of books, periodicals and catalogues. This chapter examines the tripartite structure of Tomory's history of New Zealand art. Tomory's history is largely one of painting (although in various texts he considers graphic art, sculpture, architecture, ceramics and typography) and solely a history of artists and artistic movements that derive from European culture. ${ }^{2}$ Tomory constructed a narrative that included or excluded particular periods, movements and artists, on the basis of their contribution to the development of modern painting in New Zealand. An examination is also made of ways that Tomory's writing has been interpreted and employed, both by his contemporaries and by later art historians. The chapter ends with a discussion of Tomory's writing on art criticism in New Zealand, and his lobbying for a more professional approach to this task.

\footnotetext{
${ }^{1}$ Tomory, Pattern (1968), p. 176.

2 This thesis does not allow space for a detailed discussion of Tomory's treatment of Maori art. For a discussion of this topic, see my art history honours paper. 'Tomory's texts: a discussion of Peter Tomory's New Zealand writings, 1956-1968'; Leonard Bell, Landfall, the 'primitive', and the visual arts in the 1950s'. Landfall, vol. 185, April 1993, pp. 106-1 13; Buck Nin and Baden Pere. New Zealand Maori culture and the contemporary scene, Christchurch, 1966.
} 
Tomory's narrative begins with William Hodges and John Webber, artists on board Cook's second and third voyages to New Zealand. Tomory noted that these painters were steeped in the romantic tradition, as shown by works such as Hodges' Dusky Bay (c.1775-1776), which depicts, in Tomory's words, the convention of 'the "Noble Savage" in his earthly paradise. ${ }^{\prime 3}$ Tomory described these artists as preoccupied with topographical concerns, although 'occasionally, when their imagination took charge, we can see very well their reaction to this land'. ${ }^{4}$ Tomory gave Hodges' paintings of the Pacific islands as an example of such an imaginative response, with their depiction of the 'brilliant oceanreflected light and the broken volcanic rhythms of the land'. ${ }^{5}$ Tomory placed these artists somewhat outside a history of art in New Zealand, stating that while we may 'accept these eighteenth century views as part of our visual pre-history,' we should 'hesitate to include them within our central iconology. ${ }^{\prime 6}$

Tomory dated the true beginning of what he termed the 'topographical period' to the arrival of artists on board the immigrant ships. Although their purposes varied-surveying, military strategy, advertising - for Tomory these were 'European artists discovering a new land with exotic plants and strange new natural phenomena [which] they recorded in compositions owing much to Claude or Richard Wilson. ${ }^{7}$ While, as his collection policy shows, Tomory felt topographical works were important for historical reasons, as works of art he generally considered them to be of little value. As he wrote in 1968, 'the topographical period has little or no significance in relation to the modern period'; thus any significance they could have in Tomory's history was limited. ${ }^{8}$

\footnotetext{
${ }^{3}$ Tomory, Distance (1961), p. 65.

${ }^{4}$ Ibid., p. 66

${ }^{5}$ Ibid.

${ }^{6}$ Tomory, Ascent (1968), p. 8.

${ }^{7}$ Tomory, New Zealand painting (1956), n.p.

${ }^{8}$ Tomory, Pattern (1968), p. 176.
} 
In making these statements Tomory consciously rejected the position of his Australian contemporary, Bernard Smith. Smith argued in European vision and the South Pacific, 1768-1850 that, while the first European artists to travel in the Pacific did 'all they could to cast its unfamiliar world into the pictorial conventions of the time', they nonetheless assisted in the creation of a new development in the landscape genre, which Smith labeled 'typical'. ${ }^{9}$ Smith argued that, through the addition of the new emphasis on empirical research to the existing neo-classical landscape tradition, landscape works were painted in which 'the rocks, plants, animals, peoples and the atmospheric conditions depicted were selected and organized to characterize the type of landscape painted. ${ }^{10}$ Smith proposed that in this way regional differences became important in landscape painting in the late 18th and early 19th centuries, and the foundations of contemporary Australian art could therefore be found in topographical landscape painting.

Tomory wholly rejected this argument. In a review of Smith's book, he wrote:

Dr Smith ... confuses the earnest desire for topographical verisimilitude for a reaching towards regional identity. ... Surely it is the twentieth century which saw the first real identification of artist and landscape in Australia, although one has every sympathy with the author for trying to establish a longer tradition. ... But the history of painting in Australia is similar to that of New Zealand where, although the topographical period of the nineteenth century was contributory to regional identification it has no real significance within the tradition of national identity. ${ }^{11}$

\footnotetext{
${ }^{9}$ Bernard Smith, European vision and the South Pacific, 1768-1850, Oxford: Clarendon Press, 1960 , preface.

${ }^{10}$ Ibid., p. 4. Smith's emphasis.

"Peter Tomory, Review of Bernard Smith's European vision and the South Pacific, 1728-1850 [1960], Journal of the Polynesian Society, vol. 69, 1960, pp. 416-17. Hereafter abbreviated as Tomory, review of European vision and the South Pacific (1960).
} 
Tomory viewed Smith's approach as an attempt to create a more substantial history for Australian painting, a project that had also been undertaken in New Zealand in the hope of, as he wrote in 1968, 'perhaps finding a "missing link", which would provide New Zealand's painting with a historical past and a longer tradition. ${ }^{12}$ Tomory believed that this missing link did not exist, stating unequivocally in his review that 'the artistic motives which lie behind the quasiscientific art of topography are not those which propel the regional landscape painter. The serious artist is not diverted in his search for form or image by topographic considerations. ${ }^{\prime 13}$

Tomory was however not entirely disapproving of these early artists' efforts. He acknowledged that the period was still 'remarkably rich in the number of accomplished artists', the best including Charles Heaphy, John Buchanan, William Fox, John Kinder, Samuel Brees, J.C. Richmond and George O'Brien. ${ }^{14}$ Tomory approved of what he saw as Richmond's, Fox's and Kinder's concern with the 'underlying formal structure of the landscape' rather than its 'dramatic elements'. ${ }^{15}$ Pointing to Buchanan's Milford Sound (1863) and Heaphy's Mount Egmont from the southward (1840), Tomory suggested that these painters were the only artists to show a 'revolt against the topographical iconography', although he felt it was hard to determine if these works displayed a 'personal as opposed to an official style', or whether their unusual nature stemmed simply from their being the result of 'early and untutored attempts at topography' ${ }^{16}$

Tomory credited topographical artists with teaching viewers to recognise natural phenomena that 'serious' artists would later turn into 'intuitive images': he assigned the years between 1770 and 1870 to the identification and

\footnotetext{
${ }^{12}$ Tomory, Ascent (1968), p. 11.

${ }^{13}$ Tomory, review of European vision and the South Pacific, 1728-1850 (1960), p. 417.

${ }^{14}$ Tomory, Pattern (1968), p. 177.

${ }^{15}$ Ibid., pp. 177-8.

${ }^{16}$ Ibid., p. 177.
} 
familiarisation of 'monumental and typical aspects of New Zealand landscape' ${ }^{17}$ In this way, these artists established a 'visual identity' of New Zealand, but Tomory considered this identity to be 'purely physical' and thought their work lacked any expression of feeling. ${ }^{18}$ For this reason, he could not allow them as antecedents of contemporary painting:

The general absence of this quality is the reason one cannot relate this period to those that followed. Even if we consider transitional artists like J.C. Hoyte and John Gully, who enjoyed both public demand and esteem, any element of feeling in their work is largely superficial. ${ }^{19}$

The 'transitional' was Tomory's label for the second period of New Zealand art. He identified Hoyte and Gully as the first 'professional' artists, a term that (as previously noted) he pointedly separated from 'serious'. ${ }^{20}$ These artists, he wrote, were normally bound to the desires of patrons, and therefore tended to produce works that satisfied the desire for illustrations of New Zealand's scenic attractions, or settlers' nostalgia for 'home'. ${ }^{21}$ As with the earlier topographical artists, Tomory's view was that 'romantic topographers' contributed little to the development of New Zealand painting. In fact, he used their work as a foil to that of the earliest painters of his third stage, the 'modern', which he considered to be heralded by the emergence of a 'more feeling conception' of the landscape. ${ }^{22}$

Discussion of later colonial artists is largely absent from Tomory's texts, and when he did consider them-especially non-landscape painters-he tended to be sharply critical. In the catalogue for New Zealand painting (1956) Tomory described Gottfried Lindauer as 'systematically [subduing] the Maori race, not

\footnotetext{
${ }^{17}$ Ibid.

${ }_{19}^{18}$ Ibid., p. 178.

${ }^{19}$ Ibid.

${ }^{20}$ Tomory, Distance (1961), p. 68.

${ }^{21}$ Ibid.

${ }^{22}$ Tomory, Pattern (1968), p. 178.
} 
by force of arms but by painting their portraits in the same style as he had the German burghers in his homeland.' ${ }^{23}$ Not only was Lindauer in his opinion 'no Gauguin', but C.F. Goldie was little more than a 'second-rate Lindauer. ${ }^{24}$ Bearing in mind that these artists were included in the exhibition, voicing such criticisms in the catalogue essay emphasised the lack of regard Tomory had for these artists. ${ }^{25}$ Tomory saw this period in New Zealand's art as plagued by sentimentality, his artistic bête noir; he later somewhat cynically noted 'an interesting relationship between popular sentimental attitudes and a high mortality rate. ${ }^{26}$

Tomory also discounted late-19th-century history painting, which he termed 'illustrative'. He saw this short-lived trend as the product of the new European community's desire to see its brief history recorded, combined with the 'voracious nineteenth century appetite for detailed historical data. ${ }^{27}$ The resultant works, he wrote in Distance looks our way, are 'attended by the same inaccuracies and popular distortions as their counterparts in England. ${ }^{28}$ Although he believed the trend in New Zealand was weaker than that in Britain, Tomory deemed this period deeply detrimental to the progress of painting in this country and to the development of an audience for serious painting, as this 'purely illustrative use of the art of painting effectively inoculated the general public against a ready understanding of painting as a serious art. ${ }^{29}$ Tomory concluded that the balance between serious and popular art, although remedied in England and the United States, remained at 19th-century levels in New

\footnotetext{
${ }^{23}$ Tomory, New Zealand painting (1956), n.p.

${ }^{24}$ Ibid.

${ }^{25}$ In later years, however, Tomory became uncomfortable with some of the forthright statements he made in this essay. Gordon H. Brown, personal communication to the author, 19 January 2004.

${ }^{26}$ Tomory, Distance (1961), p. 69

${ }^{27}$ Ibid., p. 68.

${ }^{28}$ Ibid., p. 69.

${ }^{29}$ Ibid.
} 


\section{Zealand. ${ }^{30}$}

The year 1890 marks a new chapter in Tomory's narrative. Tomory dated the emergence of the 'modern movement' in New Zealand painting to the last decade of the 19th century. His writing on this topic, however, shows an interesting development in his thinking over the 12 years he spent in New Zealand. In his earlier texts the birth of the modern period tends to be associated with the impact of immigrant artists who arrived in the 1890s, such as Petrus van der Velden, Girolamo Nerli and James Nairn. In 1956 Tomory described these artists as 'professional injections' into a predominantly amateur practice. ${ }^{31}$ In 1964 he cited van der Velden ('Dutch expressionist'), Nairn ('Scottish impressionist'), Nerli ('somewhat peripatetic Italian') and Edward Friström ('Swedish Fauve') as bringing with them a set of varied influences that balanced 'strong English tendencies' in the art schools..$^{32}$ In later texts, however, Tomory argued that while 1890 was a convenient selection (as this was the year that van der Velden, Nairn and Nerli all arrived in New Zealand) it was nonetheless erroneous. In the late 1960s Tomory came to stress the example these artists set rather than the stylistic influence they exerted, and suggested that they helped to energise a modern movement that was already underway. Tomory pointed to David Con Hutton, John Gibb and Alfred Walsh as artists already working in New Zealand in the 1890s who did not 'reveal any element of the topographical instinct that is so obvious in the work of both Gully and Hoyte. ${ }^{\prime 33}$ In Painting

\footnotetext{
${ }^{30}$ Ibid.

${ }^{31}$ Tomory, New Zealand painting (1956), n.p.

${ }^{32}$ Tomory, Contemporary painting (1964), n.p.

${ }^{33}$ Tomory, Pattern (1968), p. 178. Tomory noted that 'Walsh may be claimed as the first serious New Zealand artist, since he was professionally trained at the Dunedin School of Art by Con Hutton.' Gibb was born in Scotland in 1831 and trained there, and arrived in New Zealand in 1876, exhibiting widely in this country. Hutton was also born in Scotland in 1843 and trained there; he arrived in Otago in 1870 as Drawing Master, appointed by the Otago Provincial Government. Hutton established the Dunedin School of Art, later expanded into the Otago School of Art and Design, which he headed until his death in 1910. Walsh was born in Australia in 1859 and came to New Zealand as a child. As a young man he was worked
} 
1890-1950 he emphasised that 'none of the overseas artists whose arrivals punctuate the period of this study entered a barren or indifferent artistic environment. Indeed, the major steps in the evolution of twentieth century painting in this country were taken by New Zealand born artists. ${ }^{34}$

In his final texts, Tomory's emphasis was that these immigrant artists were exemplars of professional practice for New Zealand artists:

New Zealand is proud of Frances Hodgkins, but she contributed little to New Zealand culture compared to Van der Velden; besides his paintings, he passed on through his pupils an example of uncompromising integrity. ... Through [van der Velden and Nairn] both expressionism and impressionism were introduced to this country at the professional level, but this was less important than the establishment of a nucleus of serious young New Zealand artists. Girolamo Nerli, for instance, set Frances Hodgkins firmly on her course. ${ }^{35}$

Although Tomory came to limit the stylistic impact these artists may have had on New Zealand painters, he was nonetheless interested by what he saw as a stylistic adaptation in their works to New Zealand's conditions. He described this adaptation as the result of 'that sympathetic response, true of any imaginative artist, to the characteristics of light and form of the natural environment. ${ }^{36}$ Tomory perceived a movement in the development of van der Velden's Otira Gorge series from an 'objective, realist conception' to a 'subjective, expressionist one', from 'crisply-stated forms [to a] more fluid expression' ${ }^{37}$ Tomory stressed that these were painterly changes, and noted that similar

as a draughtsman for the Public Works Department, but also took lessons at the Dunedin Art School with Hutton and George O'Brien. In 1886 he was appointed to the Canterbury School of Art and taught there for 24 years. See Una Platts, Nineteenth century New Zealand artists: a guide and handbook, Christchurch:

Avon Fine Prints, 1979, pp. 103, 135, 246.

34 Tomory, Painting 1890-1950 (1968), p. 3. Tomory's emphasis.

${ }^{35}$ Tomory, Pattern (1968), pp. 179-80.

${ }^{36}$ Tomory, Painting 1890-1950 (1968), p. 3.

${ }^{37}$ Ibid. 
adaptations could be detected in the work of Friström and Nairn. ${ }^{38}$

Tomory observed that in the 1890 s an 'artistic ferment' was created, with a 'brisk, progressive artistic society in each of the major centres.' ${ }^{39}$ However, he continued, each of these societies was isolated, not only from other artistic circles, but from the broader New Zealand public, and artists struggled for sales, relying instead on the patronage of friends. Tomory saw the beginning of a decline by 1905, and noted that while the overseas artists set professional examples, they also produced 'that compulsive desire amongst New Zealand painters to travel to Europe. ${ }^{\prime 40}$ In Tomory's eyes the promise of the 1890s was not fulfilled. In his earlier texts he described the years between 1905 and 1930 as a 'wasteland', characterised by an exodus of artists that was disastrous for the infant modern movement. Tomory's list of departing artists included Owen Merton, Grace Joel, Raymond McIntyre, Mina Arndt, Frances Hodgkins, Francis McCracken, Sydney Lough Thompson and John Weeks. ${ }^{41}$ In his narrative, the modern movement's progress was largely stalled by 1918 , as many artists had already left, and more took advantage of the end of the First World War to depart for Australia and Europe, in the belief that a trip to Europe was a prerequisite for an artistic career:

This was a disastrous assumption and the art schools in New Zealand did little to correct it; in fact they nourished it with their intrusive English staffs, many of whom held to the quaint nineteenth century notion that art can be taught, whereas it is only technique that can be taught. The technique could be acquired as well in New Zealand as anywhere but New Zealand painting could not be learnt anywhere but in New Zealand. So the new blood which would have enriched the art of this land was dripping with typical New Zealand generosity into the pulsing veins of Europe..$^{42}$

\footnotetext{
${ }^{38}$ Ibid.

${ }^{39}$ Ibid.

${ }^{40}$ Tomory, Distance (1961), p. 71.

${ }^{41}$ Tomory, Pattern (1968), p. 180; Tomory, Painting 1890-1950 (1968), p. 4.

${ }^{42}$ Tomory, Distance (1961), p. 71.
} 
Tomory acknowledged that the lack of support for the professional artist in New Zealand society at this time justified artists' search for a more sympathetic environment overseas. He felt, however, that European training was of little use to the serious New Zealand artist:

Those who returned were thought to have tasted a divine elixir. But had they? Their eyes, conditioned to the grey northern light of Europe and a land of a different lay cultivated into sophisticated forms by centuries of peasants and painters, were shocked and puzzled by the brilliant Pacific light and an untamed land. ${ }^{43}$

Tomory described the artists who returned as being unable to reacclimatise to New Zealand; they 'came back sick for Europe and sick men and women do not produce good art. ${ }^{\prime 4}$ Tomory saw this period of exodus being forcibly halted by first the depression of the 1930s and then the Second World War. He wrote in 1956:

it would seem that the work of the artists of this generation [the 1930s and early 1940s] has a quality of virility totally lacking in the work of previous generations. It seems, in fact, that where artists had to stay at home they came to terms with the characteristics of New Zealand.... Now, despite the resumption of artistic emigration, there is a greater awareness amongst the younger artists of their land, and the relationship of man to that land, and there is also evidence of a greater dependence on the sensations at hand, rather than seeking for others elsewhere. ${ }^{45}$

The re-emergent modern movement was, like the painting of the $1890 \mathrm{~s}$, to find its impetus in close engagement with and observation of the New Zealand landscape. Due to the disruption of the Second World War, artists who emerged in the 1930s remained in New Zealand, meaning that 'the modern movement, instead of fragmenting like its predecessor, coalesced around its major figures to

\footnotetext{
${ }^{43}$ Ibid.

${ }^{44}$ Tomory, New Zealand Painting (1956), n.p.

${ }^{45}$ Ibid.
} 
provide a solid foundation and tradition for the fruitful decades that were to follow.' ${ }^{16}$

In his later surveys Tomory took a wider view of the circumstances which led to the rebirth of the modern movement, rather than attributing it solely to artists being forced to come to terms with the 'real' New Zealand. In Painting 1890-1950 Tomory considered the artists who stayed in New Zealand during the 'exodus', and the slow development of an arts infrastructure. Tomory expressed some sympathy for those artists who remained or returned, describing, for example, the lack of reaction to the work John Weeks brought back from North Africa. He also pointed to the continued presence of serious artists in most of the major centres: A.H. O'Keeffe in Dunedin; Margaret Stoddart in Christchurch; D.K. Richmond, and in the 1920s T.A. McCormack, in Wellington. Tomory also emphasised the importance of patronage, both direct financial support and the 'intellectual stimulus and shelter given by people such as the poet Ursula Bethell.' ${ }^{47}$ These factors led Tomory to conclude that when R.N. Field and Christopher Perkins arrived in New Zealand as part of the La Trobe scheme in the 1920s, 'the artistic ground was stony but not infertile.' ${ }^{48}$

These English painters had significant roles in Tomory's narratives, as each contributed to one of the two movements that for him characterised contemporary New Zealand painting. Tomory identified Perkins as stylistically indebted to Paul Nash, leader of the English neo-romantic movement. Perkins' influence, Tomory wrote, 'which may be detected at its best in the early work of Rita Angus', gave rise to 'what is known, perhaps frivolously, as the Dead Tree and Old Colonial House School'.49 Tomory saw Field's influence as an important

\footnotetext{
${ }^{46}$ Tomory, Painting 1890-1950 (1968), p. 5.

${ }^{47}$ Ibid., p. 4.

${ }^{48}$ Tomory, Painting 1890-1950 (1968), p. 4.

${ }^{49}$ Tomory, Pattern (1968), p. 181.
} 
factor in a return to the feeling of the 1890s. He wrote that Field's theory - 'that subject or symbol were to be sought through the expressive use of form and colour' - could be seen in his own work and also that of his students, and that in this way 'the interpretation of the New Zealand environment made by the earlier artists was to be re-adopted..$^{\prime ⿰ 0}$ Tomory also noted that both McCahon and Woollaston spent some time at the Dunedin Technical College under Field's tutelage.

Tomory identified a number of other factors which were important in fostering the modern movement in the 1930s. To Field's and Perkins' influence he added the 'undercurrent of emergent nationalism, which got its strength from the generation of the twenties'.$^{51} \mathrm{He}$ noted the importance of New Zealand artists who had returned from Europe, especially Mina Arndt, who had studied under Lovis Corinth, and Flora Scales, who had studied at the Hans Hofmann School and would later influence Woollaston. Tomory also observed that this was the time when the first affordable, well-illustrated art books appeared on the market-especially the Phaidon Press monographs-and noted that both McCahon and Woollaston studied the Phaidon book on Cézanne. Reviewing the 1930s, Tomory was of the opinion that despite the New Zealander's love for the foreign expert, the real regeneration of painting centred on Field's group of artists in Dunedin, and was reinforced by the presence there of Charles Brasch and Rodney Kennedy, pioneer collectors of modern New Zealand painting. He noted that Canterbury had a similar group of artists (including Angus) and tagged the establishment of The Group in 1927 as a significant development. To this list of artistic communities that fostered a serious attitude towards painting, Tomory added the Mapua/Motueka area, noting that Nairn, Arndt, Woollaston

\footnotetext{
${ }^{50}$ Tomory, Painting 1890-1950 (1968), p. 4.

${ }^{51}$ Tomory, Pattern (1968), p. 180.
} 
and McCahon had all painted there: 'In its way, this area played as important a part in New Zealand painting as Pont Aven had done in France, for without the continuum it provided for painting and discussion from 1939 to 1948 , it is doubtful whether painting in this country would be where it is today. ${ }^{.52}$

In his writing Tomory consistently identified McCahon, Woollaston and Angus as pioneers of the modern movement and New Zealand's senior contemporary artists. While Woollaston and McCahon had both been recognised by earlier writers, Tomory's attention to Rita Angus brought her work new prominence. ${ }^{53}$ When asked in 1985 why he singled her out, Tomory explained that it was because of the painterly quality of her work:

When I went to her house in 1958 she had all these things under her bed. There were these marvelous watercolours and they were completely different, not that kind of soft line and contour stuff but very crisp and beautiful colour. Like Woollaston you could recognise her immediately as a painter..$^{54}$

This 'standard, accepted and authoritative trio' (as Francis Pound describes them) was reinforced by Hamish Keith and Gordon H. Brown in An introduction to New Zealand painting 1839-1967, which gave the canonical status of McCahon, Woollaston and Angus lasting form. ${ }^{55}$ One could argue, as Maria Brown has, that in many ways this status holds strong today, and its longevity might be attributed to the fact that many of the original sources on modernist New Zealand painters were published by the Auckland City Art Gallery. ${ }^{56}$ For Tomory, Woollaston and Angus were 'the first consistently serious painters' to emerge in the 1930s, who were 'concerned essentially with the contemporary

\footnotetext{
52 Ibid., p. 182.

${ }^{53}$ Pound, Headlands (1992), pp. 190-92.

${ }^{54}$ Kirker, Anne, 'Peter Tomory's New Zealand years', Art New Zealand 41, Summer 1986-1987, p. 77.

Hereafter abbreviated as Kurker, Art New Zealand 41 (1986-87).

${ }^{55}$ Pound, Headlands (1992), p. 192.

${ }^{56}$ Brown, 'The history and function of the Auckland City Art Gallery' (1999), p. 145.
} 
attitude. ${ }^{57}$ To them he added McCahon, despite the fact that he only began to exhibit towards the end of the decade:

I have used the names Woollaston and McCahon because by and large they are the most mature. Woollaston is 54 or thereabouts; McCahon is 45; and I should include Rita Angus as well. The three of them are much of a painting age because they were all working in the '30s. They are interesting because neither Woollaston nor McCahon has spent any length of time out of New Zealand. We had a retrospective exhibition of both of them in Auckland about two years ago, showing paintings from 1935 up to 1962. There are no other artists, except Rita Angus, you can do this with. ${ }^{58}$

Tomory did not attempt to draw strong stylistic comparisons between the three painters. Tomory linked Angus to the romantic and regionalist movements in British and American painting, in the sense that her work was concerned with symbols of New Zealand and New Zealanders. His connection was heavily qualified:

her vision of New Zealand was certainly romantic, but it was as individual as that of Stanley Spencer in England or Grant Wood in the United States, and she probably shared with them an enthusiasm for the fourteenth century Italian and Flemish painters. Hence the clear bright colours ... and her clearly defined yet unsophisticated forms make her art more neo-Gothic than romantic. Her subjects, nevertheless, were contemporary unvarnished literal truths. The up-country railway station of Cass is as clear an identity as Mrs Betty Curnow, but the handling of colour and form enabled the artist to transform these realities into timeless emblems of a land and people..$^{59}$

In contrast, Tomory described Woollaston using land and people as 'motifs', as Cézanne had done: ' $[t]$ hey were to be resolved into static or articulated complex

\footnotetext{
${ }^{57}$ Peter Tomory, 'It started in the thirties', Listener, November 6, 1964, p. 5. Hereafter abbreviated as Tomory, 'It started in the thirties' (1964).

${ }^{58}$ Ibid. The 1963 retrospective of McCahon and Woollaston's work was originally intended to include Angus, but she declined to be involved.

i9 Tomory, Painting 1890-1950 (1968), p. 5. Mrs Betty Curnow is better known as Portrait of Betty Curnow:
} 
forms, convex light-reflecting forms, concave shadow-harboring forms, vehicles of colour and tone, but never unfeeling forms. His aim, as he has written, is to paint "the essence of feeling", and the figures, nude, and landscape [paintings] reveal instinctive truths. ${ }^{60}$ Tomory also made strong connections between Woollaston's style and German expressionist painters, noting that Flora Scales had introduced Woollaston to Hans Hofmann's colour theories, 'which enabled his style to become more fluid, more expressive. ${ }^{\prime 11}$ In 1985 Tomory recalled a conversation with Woollaston:

I remember in fact when I saw some Toss Woollastons for the first time, I mean a number of them, and I was talking to him and I said 'You must have been impressed with [Oskar] Kokoschka', and he said 'Who's Kokoschka?'. Because there was one picture there with a setting sun and it looked just like one of Kokoschka's townscapes. He'd never heard of him and yet I thought there must have been some German Expressionist background and of course there was through Flora Scales, because she trained in Munich. So I was right in a way, but he'd never heard of Kokoschka, he'd never looked at any German expressionism ...62

Nonetheless, Tomory saw Woollaston's work as an example of 'European expressionist colour and form [being] perceptively employed by a New Zealand artist. ${ }^{63}$ As with Angus, Tomory saw Woollaston as an intensely regionalist artist, describing him as having a 'will to express his own region' ${ }^{64}$ Tomory did not oppose regionalism to modernism or internationalism, as can be seen in his linking of Angus to English and American painters, or in his commentary on Painting from the Pacific. In 1964 Tomory reminisced about showing works by

\footnotetext{
${ }^{60}$ Ibid.

${ }^{61}$ Ibid.

${ }^{62}$ Anne Kirker, interview with Peter Tomory 25 December 1985. Museum of New Zealand Te Papa Tongarewa Archives, MU466/12 [41] 1985/2 P. Tomory. Hereafter abbreviated as Kirker interview, Te Papa version, part 2.

${ }^{63}$ Tomory, Painting 1890-1950 (1968), p. 5.

${ }^{64}$ Tomory, Ascent (1968), p. 16.
} 
McCahon and Woollaston to artists overseas:

the one who appealed immediately to the average European was Woollaston. His whole style, the way he arranges his landscape, the way he paints it, is an international style, in fact he doesn't create an image out of the landscape; he paints an expression of the landscape through himself. He is an expressionist, but he doesn't produce a kind of image which ties his painting to a particular region.

McCahon, on the other hand, is very much more inventive. Out of the landscapes he sees he creates definite images which belong to New Zealand and are much more readily interpreted by a perceptive New Zealander than by somebody abroad. The Europeans were all impressed by McCahon's painting, but their comments showed that Woollaston was the painter they could understand most easily. On the other hand they granted that McCahon was probably the more fundamental painter creating the more deeply felt image, stripping down what he sees into a basic philosophy, an attitude to life within New Zealand..$^{55}$

Although he drew connections between the two painters (especially in terms of their portraiture) Tomory located Angus and Woollaston at opposite ends of a continuum which he used to encompass contemporary New Zealand painting. He wrote in 1961; 'It is possible to see in the work of Woollaston and Rita Angus the two trends that largely direct New Zealand today. Woollaston, international in style, drew mainly on European expressionism and Cézanne, while Rita Angus presented a regional style which, although analogous to kindred conceptions elsewhere, maintains its individuality. ${ }^{66}$ Tomory located McCahon between these two poles, stating that he combined the 'formal analysis of the landscape' made by Woollaston with a 'symbolic content that stems from an intense regional vision, like that of Angus' ${ }^{6}{ }^{67}$ In this way, McCahon's work is located as 'complementary' to both Woollaston and Angus. When discussing

\footnotetext{
${ }^{65}$ Peter Tomory, 'What's different about New Zealand art?', Listener, 30 October 1964, p. 3. Hereafter abbreviated as Tomory, 'What's different about New Zealand art?'(1964).

${ }^{66}$ Tomory, Pattern (1968), p. 181.

${ }^{67}$ Ibid., p. 183.
} 
McCahon's work in 1968, Tomory wrote:

Intense is the key word, for the intensity of his conception has a touch of the messianic about it, equally matched by strong dynamic forms and colours. ... Complementary, too, has been his welding of the CézanneCubist-Mondrian direction to the stylized landscape forms of the quattrocento, forming an individual style which he has sustained throughout the many facets of his insight. ... McCahon is the most profound artist that New Zealand has produced and also one of the best painters, for his control of tone in an almost monochromatic range is masterly.' 68

In 1985 Tomory described McCahon as a 'tougher nut to crack' than a painter like Woollaston, who had recognisable links to the European tradition. Tomory felt McCahon had a 'unique vision', and compared him to William Blake, a 'real oddball painter in his period who created as many problems for his time as Colin did for ours' ${ }^{69}$ The profundity of McCahon's painting was an important factor in Tomory's regard for his work. As will be discussed later, the intensely symbolic nature of McCahon's painting lent itself well to the criteria on which Tomory assessed New Zealand artists.

Tomory's history of New Zealand art ends with a new development, a generation of contemporary artists (building on the modern artists-McCahon, Woollaston, Angus --before them) who emerged after the Second World War:

It was probably during this time that a true urban consciousness began to grow, for it was in the towns that artistic circles were formed which provided the impetus for the new movement, concerned as it was with self-identification of the group with its chosen environment, that is, the New Zealanders in New Zealand. National consciousness is born in the town. Furthermore, this natural population shift from country to town caused a greater proportion of New Zealanders in their new visual

\footnotetext{
${ }^{68}$ Ibid., p. 183.

${ }^{69}$ Kirker interview, Te Papa version, part 2.
} 
environment to be confronted with the urban landscape of architecture. ${ }^{70}$

The emphasis on urbanisation in this passage from Distance looks our way is mirrored in The pattern of New Zealand culture, where Tomory separated Woollaston, Angus and McCahon, with their 'indigenously developed styles', from a new generation of artists whose experience had been markedly different. Tomory made little attempt to identify a coherent school of contemporary New Zealand art:

Since the early fifties artists have proliferated, and the over-all quality of work has risen to the extent that painting in this country is now a major force in cultural development. It has, at the same time, become more diverse in direction and style.... [Woollaston, Angus and McCahon] have indigenously developed styles, for none of them has spent more than a year out of New Zealand. Although the same can be said for some of our contemporary painters, they have experienced wholly different pressures and influences. Urbanization, the maturing of the national identity, swifter means of communication, the growth of patronage, and the increasing professionalism of the schools have combined to change the traditional pattern. ... One thing is certain: the painting becomes better year by year, and more artists demand notice, necessitating a fluid critical attitude. ${ }^{11}$

Tomory saw the growth of an urban consciousness and an increased diversity of practice as the key characteristics of painting from the early $1950 \mathrm{~s} .{ }^{72}$ He observed in The pattern of New Zealand culture that the post-war years had been notable for the renewed emigration and immigration of artists. In his account of contemporary trends, Tomory continued to make note of painters who matured

\footnotetext{
${ }^{70}$ Tomory, Distance (1961), pp. 74-75. Returning to the discussion in Chapter Two, the significance of this final statement can be seen; if people's visual environment was urban, their aesthetic appreciation would be shaped in such a way as to respond to artworks which embodied the sensation of this environment.

${ }^{71}$ Tomory, Pattern (1968), pp. 183-184.

${ }^{72}$ Tomory's emphasis on urbanisation here would place hım outside Pound's assessment that 'Nationalist art and literary ideology endlessly celebrates the rustic while reviling the city.' Francis Pound, 'Emerging abstraction', in The 1950s show. Auckland: Auckland Art Gallery and New Zealand Home and Building. 1992, p. 39.
} 
in New Zealand, but his main emphasis was on the range of practice; for example, Mrkusich's emblematic paintings and Don Binney's bird-andlandscape works (in both of which Tomory detected some small connection to the medievalism of Angus' work) and as opposites, Robert Ellis and Pat Hanly, with their paintings of urban subject matter. 'Similar remarks could be made about the remainder of the established artists,' Tomory concluded, 'but no greater coherence would be achieved.' 73

In 1964 Tomory played an important role in organising (and writing the catalogue essay for) a show of contemporary New Zealand painting sent by the Queen Elizabeth II Arts Council to London, where it was shown at the Commonwealth Institute. Tomory's selection emphasised the diversity of styles that had emerged New Zealand painting by this time. The 15 artists included were Angus, Binney, Bryan Dew, John Drawbridge, Ellis, Suzanne Goldberg, Rudolf Gopas, Hanly, McCahon, Mrkusich, Peebles, Ross Ritchie, William Sutton, Woollaston and Philip Trusttum. The selection ranged therefore from abstraction to figuration, social satire to landscape, and encompassed newlyemerged and well-established painters, immigrant painters and painters recently returned from overseas. Tomory wrote in the catalogue:

Until recently, the landscape has provided the bulk of the subject matter for the New Zealand artist. From the 19th Century topographical artists came the identification of the country's natural monuments. ... If these artists were largely concerned with motif, then Woollaston is their natural successor. On the other hand, McCahon has sought in the landscape an image symbolic of his fears and hopes. These are the two tendencies apparent in New Zealand until recent years, when the rapid growth of towns, particularly Auckland, has produced an urbanized artist, more conscious of and sensitive to the human tensions of such an environment,

\footnotetext{
${ }^{73}$ Tomory, Pattern (1968), p. 184.
} 
rather than lifting his eyes to the hills. This exhibition demonstrates this new development, significantly assisted by the younger artists. ${ }^{74}$

This paragraph in many ways summarises Tomory's assessment of contemporary New Zealand practice; underpinned by the examples of Woollaston, McCahon and Angus-both their stylistic influence and their place as New Zealand's senior painters - the contemporary movement was able now to spread out in all directions.

Tomory's history of New Zealand art divided those artists who contributed to the development of modern art in New Zealand from those who did not. Throughout his texts the words 'intuitive', 'feeling' and 'sensuous' are used to describe a response to the New Zealand landscape that was opposed to 'topographic', 'romantic' or 'merely physical' interpretations. Tomory traced a line of descent by way of artists in whose work he detected the first response rather than the second, responses that were the outcome of a lengthy process of 'self-identification' with the New Zealand landscape. This notion of selfidentification (which Tomory drew from the thinking of German aesthetic philosopher Theodor Lipps) separated the 'serious' and the 'topographical' artist, and 'art' from 'illustration' in Tomory's narrative.

Tomory insisted that the process of self-identification was 'essential if the visual arts are to be significant in a particular environment. ${ }^{\prime 75}$ His notion of selfidentification is clear in this highly evocative description of the work that van der

\footnotetext{
${ }^{74}$ Tomory, Contemporary painting (1964), n.p.

75 Tomory, Distance (1961), p. 66.
} 
Velden produced in New Zealand:

as he painted, his style broadened into a powerful expressionism and the molten anger of his heart found an expressive catharsis in the molten geology of New Zealand. He found and painted the sensuous object and poured into it the energy of his angry will. Through his art others have seen and felt the crouched violence of these dark, volcanic hills. So the circuit between place and self-identification is closed. This is the potent capacity of the seen and felt image which the artist creates. ${ }^{76}$

Tomory here draws on Empathy theory, a philosophy that Rudolf Arnheim describes as a 'relatively recent outgrowth of Romantic philosophy'. ${ }^{77} \mathrm{~A}$ concept originally coined to describe the aesthetic experience, the notion of Empathy was used by theorists to distinguish aesthetic experience from 'the mere examination of visual and associative facts by which a work of art may be understood'. ${ }^{78}$

The term Einfühlung, or Empathy, was first used by Theodor Lipps. ${ }^{79}$ In his 1905 book Aesthetik: Psychologie des Schönen in der Kunst, Lipps posited three types, or directions, of enjoyment. First, we can enjoy a 'sensuous object' distinct from ourselves, such as the taste of fruit. Alternatively we can enjoy qualities within ourselves--our power or skill-and be pleased on those occasions when we exhibit these qualities. A third possibility 'uniquely combines' these two types of enjoyment: we can enjoy ourselves in a sensuous object distinct from ourselves. This is what Lipps called aesthetic enjoyment, or 'objectified selfenjoyment'. ${ }^{80}$ 'That I enjoy myself in a sensuous object', Lipps wrote, 'presupposes that in it I have, or find, or feel myself. Here we encounter the

\footnotetext{
${ }^{76}$ Ibid., p. 70.

${ }^{77}$ Rudolf Arnheim, 'Wilhelm Worringer on Abstraction and Empathy' in New essays on the psychologr of art, Berkeley, Los Angeles and London: University of California Press, 1986, p. 50.

${ }^{78}$ Ibid., p. 54.

${ }^{79}$ Elnfïhlung can be translated literally as 'in-feeling' or 'feeling in'.

${ }^{80}$ Theodor Lipps. 'Empathy and aesthetic pleasure' [1905] (trans. Karl Aschenbrenner) in Karl Aschenbrenner and Arnold Isenberg. (eds.), Aesthetic theories: studies in the philosophy of art, Englewood Cliffs, N.J.: Prentice-Hall Incorporated, 1965, p. 403.
} 
basic idea of present day aesthetics, the concept of Empathy. ${ }^{18 i}$ It is important to understand that Empathy theorists see empathy not as a form of association but rather as an internal process; as Lipps explained, "empathy" does not mean that that which I empathize, for example, power or joy or longing, is anything visible or audible, or anything outwardly perceptible, but rather that I experience all this within myself.' 82 Lipps gives the example of a storm, in which we may find 'rage' or 'threat':

If it is the fact that the activity I denote by the words 'rage' and 'threat' cannot be seen or heard but can only be felt within me, and if I nevertheless find something of that sort in a sensuous object, then I must be finding myself in this sensuous object. I experience or feel myself in it. ${ }^{83}$

Lipps noted that the word that might best be substituted for 'empathy' is 'expression': 'the form of a body expresses to me strength or health. A landscape expresses a mood. Such "expression" says exactly what we intend by the term "empathy". ${ }^{84}$ In this way Lipps proposed that the object of aesthetic experience is infused with our feelings and emotional states. The aesthetic experience that occurs before a work of art is, for Lipps, a 'very special sort of case' ${ }^{85}$ It is a 'certain mood of feeling affected when I am paying aesthetic attention, when I

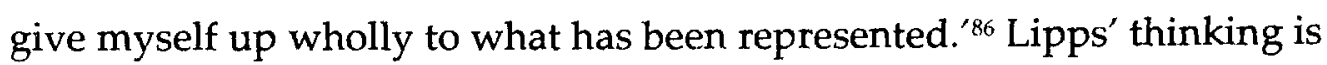
strongly reflected in Tomory's process of self-identification. The final stage of this process, Tomory writes, is reached when 'the artist or observer transfers his own self-enjoyment into the sensuous object; that is, he transmits into it the life

\footnotetext{
81 Ibid.

82 Ibid., p. 404.

83 Ibid.

${ }^{84}$ Ibid., p. 405.

${ }^{85}$ Ibid., p. 411.

${ }^{86}$ Ibid..
} 
or energy of his own will. ${ }^{\text {87 }}$ This explanation closely resembles Lipps' own description of the aesthetic experience. As Wilhelm Worringer (a German art historian, and student of Lipps', whose writing did much to bring Lipps' thinking to a wider audience) wrote, quoting Lipps:

To enjoy aesthetically means to enjoy myself in a sensuous object diverse from myself, to empathise myself into it. 'What I empathise into it is quite generally life. And life is energy, inner working, striving and accomplishing. In a word, life is activity. But activity is that in which I experience an expenditure of energy. By its nature, this activity is an activity of will. It is endeavour or volition in motion. ${ }^{\prime} 88$

Herbert Read, in his 1931 book The meaning of art, described Empathy theory as the most successful of the theories that accept 'instant contemplation' the involuntary emotional response elicited from the viewer when they first behold an art work. ${ }^{89}$ In this book Read identified Lipps as the 'greatest of all writers on aesthetics', and the writer who gave Empathy theory its classical expression..$^{90}$ Read, explaining Empathy theory to his readers, wrote:

The word 'Einfühlung' has been translated as 'empathy' on the analogy with 'sympathy', and just as 'sympathy' means feeling with, so 'empathy' means feeling into. When we feel sympathetic for the afflicted, we reenact in ourselves the feelings of others; when we contemplate a work of art, we project ourselves into the form of the work of art, and feel accordingly. This latter process is not necessarily confined to works; naturally we can 'feel ourselves into' any object we observe, but when generalized like this, there is little or no distinction between empathy and

\footnotetext{
${ }^{87}$ Tomory, Distance (1961), p. 67. Tomory's interpretation of Lipps' theory might be questioned here. Lipps asserted that empathy is not a process of experiencing an emotion that is transferred on to a certain object, but rather an internal process by which one recognises one's feelings in that object. In this way, and contrary to what Tomory suggested, the artist should not 'transmit' his energy into the sensuous object, but rather recognise his energy in it.

${ }^{88}$ Wilhelm Worringer, Abstraction and empathy: a contribution to the psycholog, of style [1908] (trans. Michael Bullock), London: Routledge \& Kegan Paul Limited, 1967, p. 5.

${ }^{89}$ Herbert Read, The meaning of art, London: Faber and Faber, 1931, p. 18.

${ }^{911}$ Ib1d. Read's own thinking on the relationship between abstract and naturalistic art was strongly influenced by Worringer, through whom he absorbed Lipps' thinking; Read dedicated his 1952 book The philosophy of modern art to Worringer, his 'esteemed master in the philosophy of modern art'.
} 
sympathy... The work of art is in some senses a liberation of personality; normally our feelings are inhibited and repressed. We contemplate a work of art, and immediately there is a release-sympathy is a release of feeling - but also a heightening, a tautening, a sublimation. Here is the essential difference between art and sentimentality: sympathy is a release, but also a loosening, a relaxing of the emotions; art is a release, but also a bracing. Art is the economic of feeling; it is emotion cultivating good form. ${ }^{91}$

In Distance looks our way Tomory drew on Lipps' ideas to define three strata of attitude in colonial society, attitudes which he believed determined or undermined the process of self-identification. The first stratum was that of the romantic intellectual, usually found in the army, survey, missionary groups and administration. The second were the 'speculator settlers', brought to New Zealand by the lure of profit. The third were the economic immigrants, who retained a 'sentimental nostalgia for "home"'. ${ }^{92}$ Each group, Tomory continued, resolved the new land in a different way. The second two groups he quickly dealt with; the economic immigrants scoured New Zealand for traces of England, and the speculators saw New Zealand in terms of scenic attractions, 'interpreted ... largely in the shape of a medieval bestiary: Rotorua, Lake Taupo-symbol, Rainbow Trout. ${ }^{\prime 93}$

\footnotetext{
${ }^{91}$ Ibid., pp. 18-20. While Tomory's writing on New Zealand art does not strongly reflect Read's thinkingotherwise we might expect to see more attention given to abstract art and an attempt to explain its originsit is interesting that his actions in the galleries he worked in did reveal Read's influence. From early in his career, Read had strong connections to German aesthetic thinking, art history and contemporary ant, first through his involvement as a young man with the Leeds Arts Club (one of the few English institutions in the first part of the 20th century to promote German cultural ideas rather than the pro-French attitude typified by the Bloomsbury Group) and then in the 1920s as a curator at the British Museum, where he forged strong connections with German academics including Worringer, whose book Form and Gothic Read translated in 1927. In this way Read became familiar with the work of the German expressionists. Tomory's own support of and interest in German expressionism in the 1950s was still seen as somewhat remarkable, and this in combination with the Germanic tone of his writing (especially his emphasis upon regional characteristics) indicates an affinity with Read's thinking. For more on the influence of German art theory and history on Read, see David Thistlewood, Herbert Read: formlessness and form, an introduction to his aesthetics, London: Routledge and Kegan Paul, 1984

192 Tomory, Distance (1961), p. 66.

${ }^{43}$ Tbid., p. 67.
} 
Tomory's adaptation of Lipps' theory is most evident in his discussion of the first stratum. Artists like Buchanan, Kinder and Heaphy, he argued, due to this 'romantic gift for identification', occasionally rose above the topographical norm. ${ }^{94}$ In these exceptional works - 'images, both visual and sensuous, which we can now recognize as true and significant', as Tomory described them in Distance looks our way - Tomory saw evidence of the last stage of selfidentification:

The topographical instinct is, in its purest form, the first stage of selfidentification, for one must first identify one's natural environment before one can enjoy it. By selection and repetition through visual experience, the next stage is reached where certain natural forms and natural phenomena above others are recognised as sensuous; that is ... not only visual objects but also feeling objects. The final stage is reached when the artist or observer transfers his own self-enjoyment into the sensuous object; that is, he transmits into it the life or energy of his own will. This is in general the theory of empathy first propounded by Theodor Lipps. ${ }^{95}$

The three stages of self-identification that Tomory described in 1961 are repeated in the three-stage development of New Zealand art that he expounded in The pattern of New Zealand culture. As previously noted, Tomory believed that while the artists of the first period - the topographical-established a visual identity for New Zealand, their work was generally lacking in feeling, and for this reason had little relation to the modern period. Likewise, artists of the second period, the transitional, only on 'rare occasions ... created an image both visual and sensuous'. ${ }^{66}$ The 'modern' stage, in contrast, Tomory felt to be marked by a 'more feeling conception' of the landscape, beginning in the 1890s and most

\footnotetext{
${ }^{94}$ Ibid.

${ }^{95}$ Ibid.

${ }^{96}$ Ibid., p. 68.
} 
apparent in van der Velden's work. ${ }^{97}$

Tomory posited a clear relationship between van der Velden and McCahon in terms of what he saw as a similar response to the New Zealand landscape. For Tomory, van der Velden was the first to recognise 'monumental symbols of human passion and integrity, hope and suffering' in the New Zealand landscape, and to resolve the landscape into a 'symbol of anger and hope'. ${ }^{98}$ Similarly, he saw in McCahon's work 'symbols of Man's hope and anguish. ${ }^{99}$ Tomory clarified this relationship in a discussion of McCahon's landscape painting in Painting 1890-1950: 'Not since Van der Velden had the New Zealand landscape been given such a majestic and expressive interpretation.' ${ }^{100}$ Using his notion of self-identification, Tomory in this way created a line of descent - a tradition of serious painting - from the late 19th century to the 1960s. In 1961 Tomory stated that the 'original romantic aptitude for self-identification' had been transformed over time into a subconscious act, concluding that 'since the end of the war there has been the invention of a coherent language of forms in all the visual arts significant within the regional environment of New Zealand.' 101

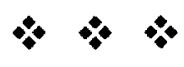

An analysis of Tomory's writing shows that his attitude towards the possibility of a national school of New Zealand painting evolved significantly between 1956 and 1968. In the catalogue for the 1956 exhibition New Zealand painting, Tomory

\footnotetext{
97 Tomory, Pattern (1968), p. 178.

${ }^{98}$ Tomory, Painting 1890-1950 (1968), p. 3; Pattern (1968). p. 179.

${ }^{94}$ Tomory, Pattern (1968), p. 179; Painting 1890-1950 (1968), p. 5.

${ }^{100}$ Tomory, Painting 1890-1950 (1968), p. 5.

101 Tomory, Distance (1961), p. 77.
} 
wrote:

there is the hope that within the next few decades, which will see in any case the fruition of a national character for New Zealand, will be seen the birth of a native school of painting ... Already Australia may boast of her own school of painting [and it] is therefore not too much to hope that within a few years New Zealand may also be proud of its artists and the independent styles and conceptions which they will have evolved out of New Zealand. ${ }^{102}$

By 1964, in the catalogue for Contemporary painting in New Zealand, the show sent to London, Tomory was expressing doubt over the possibility of a national school of painting. While acknowledging that 'the search for a national identity is a very real endeavour for a young country', he continued:

Much is written and spoken about a regional style, particularly by the seekers of a national identity. But it is very doubtful whether this exists in any marked degree, other than in the hard-edged black and white images that come through some artists' work and in the rather blunt brush work ... which is in part due to the subconscious antipathy shared by all excolonial countries to le bon facture..$^{103}$

As is indicated here, Tomory gave the term 'regional' two inflections. While he could, as noted earlier, describe Woollaston as an intensely regional artist, with a 'will to express his own region', he also viewed regionalism in a wider context, a context demonstrated by the exhibition Painting from the Pacific. From the early 1960s Tomory increasingly positioned New Zealand's contemporary painting in relation to that of other Pacific nations, on the basis of possible stylistic similarities, that he in turn related to geographical similarities.

Tomory took a connoisseurial approach to art history, and emphasised the use of the trained 'eye'. Hamish Keith describes him as an 'art historian of the old

102 Tomory, New Zealand Painting (1956), n.p.

${ }^{143}$ Tomory, Contemporary painting (1964), n.p. 
school', with a great interest in stylistic analysis. As Keith recalls, 'the thing that Peter Tomory encouraged was [that] art was a very interesting forensic business. You would find some clues and look for more clues and then make some assumptions and then you'd find some more clues which changed those assumptions.' ${ }^{104}$ These beliefs underpinned Tomory's ideas about the regional nature of New Zealand painting. In 1964, in an article for the Listener titled 'What's different about New Zealand art?', Tomory recalled disputing with Herbert Read about the validity of this approach:

He was saying that the regional aspect of art is almost done for. I disagree profoundly. I think you can even tell West Coast American painting from East Coast. You certainly can tell American abstract expressionism from the European variety.

It's difficult to say what these differing characteristics are for New Zealand because they are literally painted into the picture. There are certain ways of applying paint to canvas or hardboard by which you detect a particular artistic style. It's like handwriting. You can tell a Rembrandt from a Rubens without looking at the whole painting. You just look at three or four square inches. And you can actually say whether it's a Flemish or a Dutch painting, whether it belongs to the north or the south. 105

'So if you are looking for regional characteristics', Tomory concluded, 'you look at the paintwork, rather than the subject or the other more literary implications.' ${ }^{106}$ Tomory saw in New Zealand painting - as in Australian painting and some American painting- $a$ 'conscious rejection of European subtlety in painting. ${ }^{\prime 107}$ At this point Tomory moves into a more speculative tone. He proposes that customs in New Zealand that might seem European are really coloured by the country's colonial background, and suggests that colonial

\footnotetext{
${ }^{104}$ Hamish Keith, personal communication to the author, 9 February 2004.

${ }^{105}$ Tomory, 'What's different about New Zealand art?' (1964), p. 3.

${ }^{106}$ Ibid.

${ }^{107} \mathrm{Ibid}$.
} 
countries tend to regard anything sophisticated as effete:

I think that in the colonial countries there is a conscious rejection, in all forms of life, of the mother country's habits. I suppose it is a move towards a kind of national identity. In painting, this comes out as a revolt against sophisticated arrangements of brushstrokes. You can almost use the word 'brutal'. There is a 'brutal' application of paint. New Zealand painting in this way is closer to the American than to a European kind, although we have some artists who are more sophisticated than others.

Tomory had since his arrival been interested in the quality of the brushwork of New Zealand contemporary painting. His first impression was of flatness; he remembered being 'shocked' at the first exhibition of contemporary painting he saw, stunned by the 'complete lack of interest in the surface.'108 In 1985 he related this flatness to New Zealand artists' reliance on reproductions in art books, and attributed some of the development to the impact of the touring shows of international contemporary art. At this time Tomory also tempered his comments somewhat, noting that some artists had taken an interest in texture and brushwork, giving Woollaston as and example; it was on the basis of Woollaston's interest in painterly effects that Tomory made the comparison to Kokoschka, noted earlier. ${ }^{109}$ It appears that Tomory did feel that this lack of interest had changed dramatically in the time he was in New Zealand, and in 1964 could write that young artists were now appearing who showed a 'feeling for the paint itself.' ${ }^{\prime 10}$

In a recent article, Pound argues that this 'rhetoric of an "ex-colonial brutality" and coarseness of stroke compared to European suavity' was probably borrowed from the American art critics of the 1950s who sought to distinguish

\footnotetext{
${ }^{108}$ Tomory, 'It started in the thirties' (1964), p. 5.

${ }^{109}$ Kirker interview, Te Papa version, part 2.

${ }^{110}$ Tomory, 'It started in the thirties' (1964), p. 5.
} 
their abstract expressionist artists from European movements. ${ }^{111}$ Clement Greenberg, for example, when comparing French and American abstract painting, wrote that the French works are composed so that they 'hit the eye with a certain patness', and concluded that '[I]f "abstract expressionism" embodies a vision all of its own, that vision is tamed in Paris-not, as the French themselves may think, disciplined. ${ }^{\prime 12}$ While Pound's point is that New Zealand nationalists were continuing to import foreign thinking to define a 'national' movement, in Tomory's case it could be said that he was tapping into an international discourse in order to analyse contemporary painting in New Zealand, and in this way explain what differentiated it from - but also how it might be linked topainting internationally. Tomory's discourse of regionalism on an international level allowed New Zealand art to both remain distinct and simultaneously be seen as part of a wider context.

How has Tomory's writing on New Zealand art been received and interpreted by later art historians?

The most intensive criticism of Tomory's approach to the history of New Zealand art was made by Charles Brasch in his review (published in Ascent) of the three books, collectively titled Painting 1827-1967, that Tomory edited in 1968. ${ }^{113}$ In addition to severe reprimands over plate section and production values, Brasch differed strongly in his views on which artists should have been

\footnotetext{
${ }^{111}$ Francis Pound, 'McCahon, Mondrian and masking tape: a reading of the centre from the outermost edge', Journal of New Zealand Art History, vol. 23, 2002, p. 14.

${ }^{112}$ Clement Greenberg, 'Is the French avant-garde overrated' [1953] in John O'Brien (ed.), Clement Greenberg: the collected essays and criticism, vol. 3, Chicago and London: The University of Chicago Press, 1993, p. 156.

${ }^{113}$ Charles Brasch, Review of Peter Tomory (ed.), Painting 1827-1967, Ascent, vol. 1, no. 3. April 1969, pp. 83-86. In this series, Hamish Keith wrote Painting 1827-1890, Tomory Painting 1890-1950 and Mark Young Painting 1950-1967.
} 
discussed in depth and how New Zealand artists should be placed in generational relationships. Brasch addressed the bulk of his criticism to Tomory's text on painting between 1890 and 1950, as he felt that the artistic generations that Tomory outlined did not accurately reflect how painting had developed in New Zealand. As previously noted, by 1968 Tomory's narrative had evolved to the point where New Zealand-based artists were credited with providing the first impetus towards a modern movement, which was fulfilled in the 1940 s by artists such as McCahon and Woollaston. Brasch objected to this approach, writing that Tomory 'is not clear enough about the divisions into which New Zealand painting evidently falls: (1) pre-history (Mr Keith's booklet); (2) first New Zealand-born generation, that of $\mathrm{O}^{\prime}$ Keeffe-Frances Hodgkins-Weeks; and, quite distinct, (3) second New Zealand-born generation, that of Evelyn Page-Rita Angus-McCahon; (4) post-war (Mr Young's booklet).'114

Although acknowledging that in his book Tomory attributed the first steps towards modern New Zealand art to New Zealand-born artists, Brasch criticised him for not drawing sufficient distinction between van der Velden, Nairn and Nerli and the 'first native-born painters', arguing that the latter were:

painters born in the new world and not in the old. Both what they see and how they see are New Zealand: New Zealand, natural and man-made, is their native ground and element, and in no way strange to them as it was (and is) to men who grew up seeing the old world. The distinction seems to me essential.' ${ }^{\prime 15}$

While Tomory saw a stylistic adaptation in van der Velden's and Nairn's New Zealand paintings, for Brasch they 'could not become New Zealand painters because they did not see as New Zealanders: they had learned to see as

\footnotetext{
${ }_{114}^{114}$ Ibid., p. 83.

115 Ibid.
} 
Europeans.'116 Where Tomory argued that perception was shaped by visual environment, Brasch seems to argue that it is innate. These differing views divided the two writers over New Zealand-born artist Frances Hodgkins. Hodgkins is only briefly mentioned in Tomory's book, and Brasch appears incensed by this:

\begin{abstract}
Although she spent her last thirty years in Britain and made her name there, Frances Hodgkins remains the finest New Zealand painter just as Katherine Mansfield is still the finest New Zealand writer. To omit any account of her work as Mr Tomory does is nonsensical; lack of space will not excuse it. ${ }^{17}$
\end{abstract}

Tomory responded to this charge (and Brasch's other criticisms) in a letter to the editor published in Ascent:

Elsewhere, your reviewer castigates my brief reference to Frances Hodgkins. I can assure him, that if I was to write a short survey of Cretan art, I would exclude El Greco's work in Venice and Toledo ... what precisely are the New Zealand characteristics in Hodgkins' mature style, or does your reviewer base his statement on the evidence of her passport? ${ }^{118}$

This question of what constitutes a New Zealand artist or New Zealand art is still debated today. What is particularly interesting here is that two writers, both identified by post-nationalist critics as bulwarks of the nationalist tradition, are able to disagree fiercely over answers to this question.

Likewise, while Tomory's thinking influenced Hamish Keith and Gordon H. Brown's An introduction to New Zealand painting 1837-1969, the authors, although endorsing many aspects of his history, were still able to disagree with some of his assessments. A number of passages echo Tomory's thinking; Brown

\footnotetext{
1"t lbid., p. 84.

117 Ibid., p. 83

118 Peter Tomory, Letter to the Editor, Ascent, vol. 1, no. 4, November 1969, p. 74.
} 
and Keith observe, for example, that the colonial painters who 'derived their style from an immediate response to the landscape, or successfully adapted their existing style to what they saw around them' achieved 'by far the better results.' 1199 The authors' comment that later colonial painters 'did little more than impose on the New Zealand landscape the forms and light of a landscape concept which they had carried with them from Europe ${ }^{\prime 20}$ bears a close resemblance to Tomory's 1956 observation that these artists:

subjected what they saw to the same formula as they used for Lake Nemi or Conway Castle. In painting they did what settlers intended to doestablish their physical dominion over an alien land and impose the European pattern of life on whatever existing pattern there was. ${ }^{121}$

Like Tomory, Brown and Keith identify 1890 as the beginning of a new period in New Zealand art, and see the development of professional attitudes towards painting as one of the most significant changes at the end of the 19th century. Brown and Keith also see the promise of the 1890s as unfulfilled, and note the negative impact of the exodus of artists overseas in the following decades.

At times, however, the authors maintain a critical distance from Tomory's statements. Brown, for example, observes that Tomory's description of the years between the First World War and the depression as a 'wasteland' is a 'justifiable,

\footnotetext{
${ }^{119}$ Brown and Keith, Introduction (1969), p. 13.

120 Ibid.

121 Tomory, New Zealand painting (1956), n.p. These recognitions by Tomory, Brown and Keith undermine somewhat Pound's assertion that the main purpose of his 1983 book Frames on the land was to "undo the official twentieth century nationalist myth about early New Zealand landscape painting: to show that eighteenth and nineteenth century landscape painting here imposed various imported European conventions on the land' and dispute the "twentieth century nationalist myth of a purely New Zealand eye, innocent of all foreign conventions.' Tomory's recognition that the actions of colonial painters and colonial settlers were comparable also foreshadows the second strand of Pound's argument in this book, that 'not only was nineteenth century New Zealand landscape aesthetically' far from innocent: it was not politically. innocent' and that 'the political function of the depiction of land was its symbolic appropriation from its native inhabitants, the Maori.' See Francis Pound, 'The land, the light and the nationalist myth in New Zealand art', in Jock Philips (ed.), Te whenua, te iwi: the land and the people. Wellington: Allen \& Unwin and Port Nicholson Press, 1987, p. 48. Hereafter abbreviated as Pound, 'The land, the light and the nationalist myth in New Zealand art' (1987).
} 
though over-simplified assessment of the general artistic situation' in New Zealand at the time. ${ }^{122}$ Brown's assessment of the artists who emerged after the 1940s also differs from Tomory's. Brown does not take up Tomory's emphasis upon urbanisation, nor does he share Tomory's reluctance to assert similarities between contemporary painters, as shown by his statement that:

If anything, developments over the last ten years have been remarkable for their variety. No greater contrast could be imagined than that between the uncompromising realism of Don Binney ... and the elegant, sophisticated abstraction of Milan Mrkusich or Don Peebles. Binney's origins are in the Coonskin preoccupations with his immediate environment while those of Mrkusich and Peebles are undoubtedly in the careful observation of European models, yet all three painters exhibit stylistic similarities. The specific interest in the light and rigidly defined forms obvious in their work is equally obvious in the work of other New Zealand painters. ${ }^{123}$

It is interesting to contrast this assessment of Binney and Mrkusich with the following comment by Tomory, from 1968:

If some continuity of conception and attitude can be detected, then it is in the most general way, and perhaps not occasioned by familial ties, but through coincidence or accident. One might say, therefore, that Milan Mrkusich and Don Binney exhibit, in the former's emblematic paintings and in the latter's bird and landscape pictures, the same medievalism that inspired Rita Angus. ${ }^{124}$

Brown's assessment is based on painter's interpretation of the New Zealand landscape and light. Tomory was more interested in the effects of an increasingly urbanised culture on contemporary painters. Thus while for Tomory Hanly represented 'urbanized and more sophisticated trends' in New Zealand painting,

\footnotetext{
${ }^{122}$ Brown and Keith, Introduction (1969), p. 97. As noted, Tomory (in his texts from the 1960s) had also felt the need to moderate his earlier assessments of this period, and his revised opinions, as displayed in Painting 1890-1950, although far briefer than Brown's, canvas the same ideas.

${ }^{123}$ Ibid., p. 179.

${ }^{124}$ Tomory, Pattern (1968), p. 184.
} 
for Brown he is an example of a painter who was significantly affected by the New Zealand light and whose experiences in Europe allowed him to discover elements apparently essential to New Zealand painting.' ${ }^{125}$

Tomory's and Brown's positions, however, are not that far apart. Both examine New Zealand art in terms of a response to the environment; it is the process by which they arrive at their conclusions that differentiates the two. Tomory, using ideas drawn from Empathy theory, seeks a 'feeling' response to the landscape. In Brown and Keith's history the link between art and environment is more direct. In their introduction they famously wrote:

\begin{abstract}
However, while the attempt to trace such patterns provides a theme in this book, the general purpose in writing it springs more from a desire to present some sort of introduction to New Zealand painting rather than a sustained thesis. At least two main patterns emerge: a general orientation towards landscape, not only as a readily available subject matter but as a source of imagery capable of profound implications, and a positive response on the part of a number of more important New Zealand painters to the distinctive qualities of New Zealand light. ${ }^{126}$
\end{abstract}

In their introduction Brown and Keith also noted Tomory's thinking on

New Zealand light, quoting his description of the Pacific light which burns and bleaches, resulting in a characteristic black and white contrast. ${ }^{327}$ As Damian

Skinner has noted, it was at the end of the 1960 s that the history of New Zealand art began to be seen as a 'series of linked moments':

What held this new approach together was the idea that New Zealand's 'hard light' produced a hard-edged style in New Zealand painting. By reference to the hard light, art historians could cope with differences in contemporary art (say the abstract paintings of Milan Mrkusich and the realist paintings of Don Binney) as well as link artists from different centuries (both Kinder and Binney responded to the bright light and thus

\footnotetext{
${ }^{125}$ Ibid.; Brown and Kenth. Introduction (1969), p. 177.

${ }^{126}$ Brown and Keith, Introduction (1969), p. 13.

:27 Tomory, 'What's different about New Zealand art?' (1964), p. 3.
} 
produced images of great clarity). The hard light and landscape tradition was just the ticket for countering the lack of previous art history and historical research. ${ }^{128}$

Francis Pound has convincingly shown that the claim for hard clear New Zealand light and the argument that this light should cause a hard-edged style of painting (what Pound calls 'meteorological determinism') is directly related to wider stylistic concerns in this period. ${ }^{129}$ Pound associates the call for a clarity of style with the 'wider move in painting, in the 1930s, here and in England, towards a clarified, formalized naturalism' tied to the writing of Clive Bell and Roger Fry. ${ }^{130}$ Pound traces a history of the hard clear light rhetoric from the $1930 \mathrm{~s}$ through to Tomory's comments on Pacific light and to Brown and Keith's Introduction. These claims, he contends, can 'easily be countered, for in every case where a painter or critic calls for clarity ... it can be shown that the call reflects current stylistic concerns.' ${ }^{131}$ Pound observes that the 'cult of clarity' was not specific to New Zealand, but can be found in America, Australia and England; logically, it should therefore have been rejected as foreign, but nonetheless nationalist writers and artists claimed it as a product of New Zealand nature itself.

Pound views Tomory's adoption of the rhetoric of harsh clear light in the 1950 s as 'another instance of nature used as an alibi for style'. ${ }^{132}$ Tomory certainly entered wholeheartedly into the dialogue concerning New Zealand's unique light and artists' response to it. From 1956: artists 'came to see ... that the wide,

\footnotetext{
${ }^{128}$ Damian Skinner, Don Binney: ngā manu ngā motu-birds/islands, Auckland: Auckland University Press, 2003, p. 4.

${ }^{129}$ See Pound, 'The land, the light and the nationalist myth in New Zealand art' (1987), pp. 48-60, and Francis Pound, 'Harsh clarities: meteorological and geographical determinism in New Zealand art commentary refuted', Parallax, Winter 1983, pp. 263-269. Hereafter abbreviated as Pound, 'Harsh clarities' (1983).

${ }_{130}$ Pound, 'Harsh clarities' (1983), p. 148.

${ }^{131}$ Ibid.

${ }^{132}$ Pound, 'The land, the light and the nationalist myth in New Zealand art' (1987), p. 54.
} 
bright Pacific light bleached out the colours and threw the contours of forms into sharp relief.' 133 From 1961: painters who returned from Europe to New Zealand came back 'conditioned to the grey north light of Europe and ... were shocked and puzzled by the brilliant Pacific light' ${ }^{134}$ And in 1968 he continued to discuss the ways that Nerli, van der Velden and Nairn adapted their styles in response to the New Zealand conditions. ${ }^{135}$ In 1964 Tomory explained that light was important because of what it did to colour, and 'hence the difference between New Zealand painting and European painting is startling. ${ }^{136}$ The light in New Zealand, Tomory continues, 'tends to turn everything to black and white'; he made a comparison in this respect to Greece, surrounded, like New Zealand, by water and sharing the same brilliant light. ${ }^{137}$ Likewise, the coastal nature of Japan, Australia, New Zealand and West Coast America had underpinned the 1961 exhibition Painting from the Pacific.

Yet elsewhere Tomory observed, as Pound highlighted in the 1980s, that the use of light by New Zealand painters was a conscious stylistic decision. Tomory connected the use of strong light casting deep shadow to international movements. He described how Perkins added to the traditional English romantic interpretation of the landscape the surrealist technique of 'over-sharply defining an object or objects and bathing them in a clear, unnatural light, thus emphasising the romantic magnification or personification of an individual natural or man-made form. ${ }^{\prime}{ }^{138}$ Tomory cast this trend (which he identified as existing simultaneously in Britain, America and Australasia in the 1930s) into the past and saw in Buchanan's Milford Sound and Heaphy's Mt Egmont from the

\footnotetext{
${ }^{133}$ Tomory, New Zealand Painting (1956), n.p.

${ }_{137}^{137}$ Tomory, Distance (1961), p. 71.

${ }^{135}$ Tomory, Painting 1890-1950 (1968), p. 3

${ }^{136}$ Tomory, 'What's different about New Zealand art?' (1964), p. 3.

${ }^{137}$ Ibid., p. 5.

${ }^{138}$ Tomory, Painting 1890-1950 (1968), pp. 4-5.
} 
southward 'manifestations' of this surrealist technique of an isolated object 'lit by a hard, unnatural light', and (jumping forward in time) connected these artists to the writing of Bell and Fry, and the promotion of significant form and the elimination of the subject. ${ }^{139}$

None of this is to deny, however, that there was a deep interest in the quality of New Zealand's light-a deeply self-conscious interest - that persisted in the 1950s and 1960s, as evidenced by this exchange between Hamish Keith and Patrick Hanly in 1979:

H.K.: Looking back now, there was a lot of talk then about light. We'd put the Great New Zealand Light on the front of our bicycles-for illumination, we thought. Did that have any influence?

P.H.: It must've done. We were all there at the same time talking about light, so one was contributing to that discussion. It wasn't something that someone else was doing and you were joining in. It was happening all at the same time. ${ }^{140}$

\section{$* *$}

Francis Pound frames Tomory as the first in a new generation of New Zealand art critics who assumed the authority previously held by the 'literati', or those writers and commentators, primarily interested in New Zealand writing, who also wrote on the visual arts. Although Pound acknowledges Tomory's difference from this previous generation, his conviction remains that Tomory still subscribed to the nationalist myths. ${ }^{141}$ Pound regards the re-shaping of the canon in Tomory's writing and actions as director as the next evolution of the

\footnotetext{
139 Tomory, Ascent (1968), p. 10.

141) Hamish Keith, 'Patrick Hanly: a conversation with Hamish Keith', Art New Zealand 14, 1979, p. 46.

${ }^{141}$ See Francis Pound Headlands (1992) and 'Painting and Landfall, and painting as literature's death', Landfall, vol. 185, April 1993, pp. 78-85.
} 
Nationalist canon; the new generation of museum professionals, he writes, rejected the literati's canon as 'too literary, too illustrative, too lacking in formal interest', but the similarities between the two generations are strong; both sought a national style, both presumed this style will be figurative, and both repeated the mantra of harsh clear light. ${ }^{142}$

Tomory's place in Pound's discussion is as a late nationalist writer who, aithough familiar with modernist art history, continued to propagate what Pound identifies as nationalist myths of light, landscape and place. Pound therefore uses extracts from Tomory's writing in order to support or illustrate his revision of these myths. I would argue, however, -along with Wystan Curnow - that in Pound's writing the original context of the texts he draws upon is often overlooked in favour of adding strength to his polemic. In his review of Pound's The space between: Pakeha use of Maori motifs in modernist New Zealand art (1994) Curnow noted that he was as concerned about the methods of Pound's argument as about the argument itself. ${ }^{\prime 13}$ Curnow chose in his review to interrogate Pound's use of quotation, as he felt it related to 'the broader issue of appropriation, the use of intellectual "property", and is crucial to his construction of Bad Nationalism.'144

Curnow tackled Pound's use of quotation head-on. Focusing on the first page of Pound's book, where Pound quotes twice from the work of New Zealand poet and anthologist Allen Curnow, Curnow took the quotations selected by Pound, reinserted them into their original context and removed ellipses to restore sentences to their full length. In doing so, Curnow showed how Pound had manipulated Allen Curnow's texts. As Curnow writes: 'All this cutting and pasting changes the meaning; it constructs the author as a dogmatic proponent of

14.2 Pound, Headlands (1992), p. 192.

${ }^{142}$ Curnow, 'Sewing up the space between' (1995), p. 18

${ }^{144}$ Ibid. 
insularity, and makes him appear as one-eyed as Pound would want him to be for the purposes of his argument. ${ }^{145}$ Allen Curnow is not the only figure to have received this cut-and-paste treatment. As the following example shows, Pound has also selectively used quotations from Tomory's texts to support his arguments. On page 58 of The space between, Pound writes:

The 'absorption' of the Polynesian 'primitive' answered also to that Nationalist New Zealand revolt which Auckland City Art Gallery director Peter Tomory proclaims: 'a revolt against sophisticated arrangements', 146 fuelled by that 'subconscious antipathy shared by all excolonial countries' for the 'effete aspects of European culture.'147 What Tomory had remarked of Rita Angus' recourse to the 15th century European 'primitives', might be equally applied to Pakeha recourse to the traditional arts of the Maori: 'this selection of unsophisticated influence would come naturally to the painter concerned with an ex-colonial regionalism.' ${ }^{\prime 48}$ If New Zealand art sought 'something strong, and, perhaps, primitive', it was also in order to 'find a New Zealand school of painting' suited to 'express that strength and vitality which has produced the Kiwis and the All Blacks'. ${ }^{149}$ It was to assert what Tomory called 'a quality of virility totally lacking in the art of previous generations' of New Zealand artists. It was to announce the fruition of a national character for New Zealand ... the birth of a native school of painters who have not since their cradle days had their art emasculated by the fevers of Europe'. .50

A reader unfamiliar with Tomory's writing could easily assume from this assemblage that Tomory argued that a specifically New Zealand art might 'naturally' or logically find its origins in the 'primitives', whether this was the 15th-century Italian painters or traditional Maori art. An unfamiliar reader might also assume that all the quotations in this paragraph - as it is not otherwise

\footnotetext{
145 Ibid.

${ }^{146}$ Tomory, 'What's different about New Zealand art?' (1964), p. 3. Pound cites this article as 'What's new about New Zealand art'.

147 Tomory, Contemporary painting in New Zealand (1964), p. 3.

148 Tomory, Pattern (1968), p. 181.

149 Anon, 'Art notes', Art in New Zealand, vol. 17. no. 6, January-February 1946, p. 46.

${ }^{150}$ Tomory, New' Zealand painting (1956), n.p.
} 
indicated in the text-are drawn from Tomory's writing, and equally easily assume that they might all be drawn from the same text. Neither of these assumptions is true. The quotations are from five different texts; four by Tomory (a 1956 catalogue essay, a 1964 catalogue essay, a 1964 article and a 1968 essay) while the quotations in the third sentence are drawn from an anonymous writer in The Arts in New Zealand in 1946. Nor does Tomory in his texts ever encourage the notion that contemporary art (which is always contemporary European or Pakeha art in his narrative) might find its roots in traditional Maori art.

The first quotation comes from the 1964 article 'What's different about New Zealand art?'. It is drawn from the section where Tomory considers how excolonial countries share a conscious rejection of the 'habits of the motherland', manifested in painting by 'a revolt against sophisticated arrangements of brushstrokes. ${ }^{\prime 151}$ The second and third fragments are drawn from Contemporary painting in New Zealand (1964), also concerning the possibility of a regional style, which Tomory feels can not be pinned to anything more than:

the hard-edged black and white images that come through some artists' work and in the rather blunt brush work-coarse, some Europeans might say - which is in part due to the subconscious antipathy shared by all ex-colonial countries to le bon facture, connoted generally with some of the effete aspects of European culture. ${ }^{152}$

Though the original meaning of the fragments is not lost, the speculative and somewhat tentative tone of their original context is. Through conflating these sentences, Pound gives these speculative statements more force than they were originally voiced with, so that they indeed sound like proclamations of a revolt.

In the next sentence Pound writes:

\footnotetext{
151 Tomory, 'What's different about New Zealand art?' (1964), p. 3. The section of the sentence that Pound cites is in bold.

${ }^{152}$ Tomory, Contemporary painting (1964), n.p. The sections of the paragraph that Pound cites are in bold.
} 
What Tomory had remarked of Rita Angus' recourse to the 15th century European 'primitives', might be equally applied to Pakeha recourse to the traditional arts of the Maori: 'this selection of unsophisticated influence would come naturally to the painter concerned with an ex-colonial regionalism.'

This quotation comes from Tomory's contribution to The pattern of New Zealand culture. Suggesting that Tomory's observation of the early-Renaissance influence upon Angus might equally be applied to 'Pakeha recourse to the traditional arts of the Maori' does not accurately reflect Tomory's opinions on European artists' use of Maori motifs. In his endnotes Pound acknowledges this, writing: 'Tomory's constant rhetoric of anti-sophistication and refusal of the European effete is itself primitivist, even though Tomory advised against the 'absorption' of Maori motifs, since he associated them with touristic advertising, and thought the conditions appropriate to a properly primitivist use of non-European art did not exist in New Zealand.' 153

Even in this qualification Pound simplifies Tomory's argument. He is right to assert that Tomory felt New Zealand painters had no need to ape the early-20th-century modernist enthusiasm for 'primitive art'. Tomory in his Landfall article argued that 'enthusiastic reception' of primitive art by European painters from the end of the 19 th century stemmed from the stagnation of European imagery at this time and the growing 'disillusion' among 'thinking men' as 1914 approached; the continuation of the European painting tradition, he wrote, has been dependant on its ability to absorb such influences. ${ }^{154}$ This however was not the case in New Zealand:

In New Zealand, anyone may see that none of these particular

\footnotetext{
${ }^{153}$ Pound in this footnote advises readers to refer to Leonard Bell's 'Landfall, the 'primitive', and the visual arts in the 1950s', Landfall, vol. 185, April 1993, pp. 106-113.

${ }^{154}$ Tomory, Landfall (1958), p. 167-168.
} 
circumstances occurred to produce this rush of primitive blood to the head. Here is a land embedded in the Pacific with its own virile indigenous art and inhabited by Europeans who over a hundred years have produced the beginnings of a civilization quite different to that of Europe. And yet suddenly there is this same yearning for the 'impact of primitive art'. This is a book-learnt yearning sprouting from busy browsers in bookshops. 155

Tomory did note that it was 'of course, possible for the European artist in New Zealand to borrow from Maori art, but any mouthful he takes must be fully digested.' ${ }^{156}$ Tomory's objection here was the same as it was to-in fact, follows on from his discussion of - the importation of the British neo-romantic traditions masked as a New Zealand style. Half-digested adaptations were not, for Tomory, 'serious' art. While Tomory did link the use of Maori motif with touristic kitsch, he notes that Maori motifs had come to be perceived in this way because of the manner in which they had been appropriated for use in advertising, rather than because such motifs were inherently kitsch. Tomory was most concerned by the appropriation of these motifs into a pseudo-primitive art:

What is more serious is the rather sorry attempt made by certain New Zealand artists in adapting the elements from these indigenous cultures into European idioms. There were first the illustrator ethnologists whose work had historical value but no painterly value, and I think their case can be allowed to rest, but what needs examining more closely is the adaptation of elements in the more serious painterly sense. It is almost simply a case of too much book learning..$^{57}$

As this shows, to cite Tomory's texts in an argument for the validity of traditional Maori art as a well-spring of contemporary New Zealand art is to seriously misrepresent his ideas.

${ }^{155}$ Ibid., p. 168.

${ }^{156}$ Ibid.

${ }^{157}$ lbid., p. 167. 
The next sentence in Pound's paragraph is more easily dealt with - it is not actually by Tomory, although Pound does not indicate this in the paragraph, and the reader must refer to the endnotes to discover this. Pound links this search for 'something strong, and, perhaps, primitive', to Tomory's detection of 'a quality of virility totally lacking in the art of previous generations' of New Zealand artists. This and the final quotation in Pound's paragraph come from Tomory's catalogue essay New Zealand painting (1956). This 'virility' has nothing to do with the inspiration drawn from the primitive, but rather refers to those modernist artists who emerged during the depression, and who were prevented from leaving New Zealand by the Second World War. In full, the sentence reads: 'Therefore there is a hope that within the next decades, which will see in any case the fruition of a national character for New Zealand, will be seen the birth of a native school of painters who have not since their cradle days had their art emasculated by the fevers of Europe. ${ }^{\prime 158}$ What is framed as an announcement in Pound's text is actually a hopeful prediction in the original. Moreover, by the end of his time in New Zealand Tomory had himself come to question what he had written here, feeling that he had not known enough about the history of New Zealand art when he voiced the very definite opinions the essay contains. ${ }^{159}$ This in itself reveals one of the major flaws of Pound's practice; he occludes the fact that the texts come from a range of sources and from a 12-year period, within which - as has been shown-Tomory's ideas about New Zealand art developed markedly.

1 accept that criticism such as this opens my own use of quotation and provision of an adequate context for extracts up for scrutiny. However, given that Tomory's texts are not usually read in the original but more often by way of

\footnotetext{
${ }^{158}$ Tomory, New Zealand painting (1956), n.p. The sections of the paragraph that Pound cites are in bold. ${ }^{159}$ See footnote 25.
} 
quotation in other, better-known texts (how many readers, for example, will have read Tomory's 1958 essay in Landfall rather than Pound's extracts from that text in Headlands?) I think it important to show that at certain times his writing, removed from its context, has been used to reinforce arguments Tomory did not make and to exemplify ideas that he did not support.

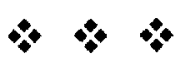

As noted in previous chapters, Tomory's various endeavours at the Gallery - the consolidation of the collection, the showing of international modern art-were undertaken in an attempt to educate audiences about art in order that they might come to support New Zealand's artists of their own volition. The lack of a receptive audience for the visual arts in New Zealand was exacerbated, in Tomory's opinion, by a lack of good art criticism. For Tomory the role of the critic was not to find fault with works of art, nor to instruct the artist, but to analyse art and interpret it for the 'interested audience'. ${ }^{160}$ Van der Velden served as Tomory's example of how the lack of an understanding audience could negatively affect the artist. Noting that van der Velden had limited success in New Zealand, he painted a sorry scenario of an embittered, alcoholic old man, the 'tragedy of the serious artist brought to his knees, not by antagonism but by the sheer indifference of society. ${ }^{\prime 161}$

Amateur art criticism, exemplified by that published in the literary quarterly Landfall, was the focus of Tomory's critique. Tomory felt that New Zealand's writers on the arts were largely unable to mediate between artist and audience: they were generally ill-equipped for the task they performed, and he

\footnotetext{
${ }^{160}$ Tomory, Landfall (1958), p. 164.

${ }^{161}$ Tomory, Pattern (1968), p. 179.
} 
concluded that the combination of a lack of properly informed opinion on the part of art commentators, and a lack of professionalism on the part of painters, resulted in a cult of amateurism. Amateur critics could, to his mind, only mouth indiscriminate encouragement; they did not possess the ability to 'sweep away the dross and explore what is good' and as a result were unable to encourage serious painting. ${ }^{162}$

Francis Pound has identified Landfall as the most influential site of New Zealand art criticism from the late 1940s to the late 1960s. ${ }^{163}$ In Landfall during this period Pound sees the first attempt to establish a canon of New Zealand art; the 'literati', he observed, were 'already practised canon makers in their own field' and felt the need to be selective in their regard, both for intellectual reasons and because space for the reproduction of works in the journal was restricted. ${ }^{164}$ The writing in Landfall, he argues, was closely tied to the nationalist project of defining a New Zealand identity and the search for a national style of arts and letters. Most art of the nationalist period, writes Pound, was literary in nature and the literati formed the first audience for this art:

from about 1930 to about 1970 in New Zealand, during what may be called the regionalist or Nationalist period, art was inextricably literary.... The kind of audience Nationalist art had first, the kind of audience which inaugurated it, and which published criticism about it, was very largely, or most noisily, a literary audience. Nationalist painting shared with the literati all their myths and predispositions. ${ }^{165}$

In his essay, Pound constructs an opposition between 'a nationalist rhetoric of words and paint', typified by the Landfall school of art writing, and 'a

\footnotetext{
162 Tomory, Landfall (1958), p. 165.

163 Pound, Headlands (1992), p. 187.

164 Ibid.

165 Ibid.
} 
new professionalism', of which Tomory was the first exemplar. ${ }^{166}$ Pound's contrast is between the 'literati' and a 'new generation of critics' - the museum professionals. Pound describes a scenario where the 1950s saw a shift in influence from the literati to writers like Tomory, who were more interested in the formal or painterly qualities of painting. Pound pinpoints the shift in critical dominance to 1958 and in particular to Tomory's essay 'Looking at art in New Zealand', published in Landfall that year.

In the 1940s and 1950s, Pound explains, Colin McCahon, Doris Lusk and Toss Woollaston were identified by the literati as among New Zealand's leading artists, while John Weeks and T.A. McCormack were also occasionally favoured. ${ }^{167}$ In the 1950s, however, Eric Lee-Johnson was increasingly singled out as the artist who embodied nationalist ideals. As evidence, Pound cites E.H. McCormick's Eric Lee-Johnson (1956), the first monograph published on a living New Zealand artist. ${ }^{168}$ In the introduction to the book, editor Janet Paul explained why Lee-Johnson was selected as the first subject of what was intended to be a series of monographs:

Eric Lee-Johnson has an awareness and an accuracy of observation rare in New Zealand. He also has a fine perception of the character of place or person or inanimate object; and he is a good draughtsman. It is his double ability as a good draughtsman to comment on the nature of what he draws, that gives to Lee-Johnson's work its special character. ... It is particularly in [his] character-revealing paintings of house or landscape that Lee-Johnson stands out as a peculiarly New Zealand artist. ${ }^{169}$

In the Landfall essay, published two years after the Lee-Johnson monograph, Tomory decried the poor state of art criticism in New Zealand, the

\footnotetext{
150 Ibid., pp. 189-90.

167 Ibid., p. 190.

${ }^{168}$ Ibid. E.H. McCormick, Eric Lee-Johnson. Hamilton: Paul's Book Arcade, 1956. Hereafter abbreviated as McCormick, Eric Lee-Johnson (1956).

${ }^{109}$ Janet Paul, 'Introduction' in McCormick, Eric Lee-Johnson (1956), n.p.
} 
literary nature of art writing in Landfall, its support of the Lee-Johnson school, and the consequences of this support for New Zealand art. Pound extracts from this essay at length for his own argument. In the essay, Tomory deplored the amateur nature of art criticism in New Zealand, noting that:

many a serious artist has been ignored partly through the fact that critics have been singularly insensitive to painting. ... One must respect at all times the ability of many New Zealanders who have a wide interest in the arts ... but it is true, unfortunately, that it is not Philistinism necessarily that depresses the sensitive artist, but the misguided criticism administered by those that profess to cherish him. ${ }^{170}$

Pound identifies the last sentence of this passage as an unspoken reference to Fairburn's derision of McCahon's painting in a 1948 Landfall review. ${ }^{171}$ Tomory also criticised the literary art critics for supporting the strain of New Zealand neo-romanticism, which 'might be called the early colonial house o'ergrown by the native bush cliché. ${ }^{172}$ Pound sees this passage as another unspoken reference, this time to McCormick and Lee-Johnson. He writes:

This art is damned as merely 'illustrative'-and, by implication (an implication Tomory was soon to spell out elsewhere), illustrative of the poems and prose of those literary men and women who presume to play the role of art critic. ${ }^{173}$

In Distance looks our way, Tomory wrote that there was a 'marked imbalance of evaluation ... of the illustrator and the serious artist. ${ }^{174}$ In 1985 Kirker asked Tomory about this statement. Tomory replied that it was a problem in Britain at the time as well-literary people with little visual sense who saw art as

\footnotetext{
${ }^{170}$ Tomory, Landfall (1958), pp. 165-166.

${ }^{171}$ Pound, Headlands (1992), p. 191; A.R.D. Fairburn, 'Art in Canterbury: some notes on the Group show', Landfall 5, vol. 2, no. 1, March 1948, pp. 49-50.

${ }_{172}^{17}$ Tomory, Landfall (1958), p. 167.

${ }_{173}$ Pound, Headlands (1992), p. 191.

${ }^{174}$ Tomory, Distance (1961), p. 78.
} 
illustration. He considered Beaglehole, Brasch and Fairburn to all write 'extremely well, but [not] particularly perceptively' on the visual arts, as they had a 'blinkered view that paintings were there to illustrate their poetry or illustrate some aspect of New Zealand.'175 Tomory felt that this was a problem that had to be surmounted in order to 'get contemporary art anywhere at all', and recalled that efforts in this direction resulted in considerable friction. ${ }^{176}$

'Illustration' has a second meaning in Tomory's writing, linked to the neoromantic movement. The romantic interpretation of New Zealand was given a particular place in Tomory's art history. In his description of the modern movement, Tomory saw painting as taking two directions, one that he considered to be serious, the other more illustrative. The first direction was exemplified by Angus and Woollaston, who emerged in the 1930s as 'the first consistently serious painters, concerned essentially with the contemporary attitude.' ${ }^{\prime 17}$ In contrast, the second direction stemmed from the tendency of romantic movements to arise in times of social upheaval, manifested here in the romantic tendencies of New Zealand painting during the depression. Tomory also acknowledged the impact of the poets of the period, who sought 'symbols which would define the land as New Zealand and themselves as New Zealanders' and the influence of Roland Hipkins' and Perkins' introduction of British neo-romanticism. ${ }^{178}$

In Tomory's opinion the New Zealand neo-romantic movement could amount only to illustration 'for the idea behind it was English romanticism lifted whole without a thought being spent on adapting it. ${ }^{\prime 179}$ In the Landfall essay,

\footnotetext{
${ }^{175}$ Kirker interview, Te Papa version, part 1.

${ }_{176}^{176}$ Ibid.

177 Tomory, 'It started in the thirties' (1964), p. 5.

178 Tomory, Painting 1890-1950 (1968), p. 4.

179 Tomory, Landfall (1958), p. 167.
} 
Tomory placed great weight upon this distinction between 'art' and 'illustration':

I have been trying to stress the painterly qualities of painting, because I think these the most important. There are hidden dangers lying in wait for the person who reads off the subject of a painting, as though it were a literary statement. The subject ... requires to be 'read' or discovered in the language of paint ... it is the artist's manipulation of this language which will communicate his idea ...We should therefore be able to distinguish quite clearly what is art and what is illustration. ${ }^{180}$

Illustration, for Tomory, was art that depicted the familiar without any 'critical acuteness' - what in the eighteenth century had been called 'furniture painting'. In late 1950s New Zealand:

The process has been going on for so long that what is at best mediocre illustration of the familiar, has become art in the eyes of most of us, so that when we are shown a painting which sets our eyes exploring and makes us think, we almost instinctively reject it because instead of being an air cushion of placid familiarities, it is a nettlebed of sharp stimulants. ${ }^{181}$

By relocating an English style to New Zealand, painters of the Lee-

Johnson school were working in terms of the illustrative and familiar. 'To replace a Nash oak root with a kauri root', wrote Tomory, 'does nothing for New Zealand painting except to send it up a picturesque $c u l$-de-sac. ${ }^{\prime 12} \mathrm{He}$ saw this particular style as 'propped up largely by the literary art critic', and stated that painting and sculpture had suffered at the hands of such critics, as their interpretation of art works in terms of a literary idea meant that 'the fact that both painting and sculpture are visual arts is quite forgotten. ${ }^{\prime 183}$ Tomory made it amply clear that the romantic realist painting favoured by some critics as a

\footnotetext{
${ }^{180}$ Ibid., p. 162.

${ }^{181}$ Ibid., p. 163.

182 Ibid., p. 167

${ }^{183}$ Ibid., p. 164.
} 
potential national style was in fact the New Zealand version of British neoromanticism, absorbed largely by way of Perkins' teachings. ${ }^{184}$

Tomory's criticism must be seen in the context of the British art world that he had recently left. As Richard Lummis has noted, Tomory's previous position with the British Arts Council would have 'afforded him a front row seat to the downfall of neo-romanticism in England. ${ }^{185}$ In Britain in the mid 1930s a new representation of landscape had emerged, a modernist reconsideration of the topographical tradition led by Paul Nash and Graham Sutherland. ${ }^{186}$ British critic Raymond Mortimer was among the first to use the term 'neo-romantic' in relation to British painting; he identified Frances Hodgkins, Sutherland, Ivon Hitchens and Henry Moore as artists whose approach shared 'an identification with Nature, a visionary quality and a rejection of European humanism. ${ }^{187}$ In a 1947 article on the 'new romanticism in British painting', Kenneth Clark emphasised the importance of the neo-romantic identification with nature, naming Moore, Sutherland and John Piper as leading exponents in the movement. ${ }^{188}$ Critiquing the post-impressionist movement in Britain, which

\footnotetext{
${ }^{184}$ As the comment about the 'Nash root' demonstrates, Tomory noted early on that romantic realism was by no means a 'homegrown' style of the type the some commentators were searching for. He observed again in Distance looks our way that Nash's neo-romanticism had a general influence on New Zealand art from the 1930s to the 1950s (p. 74) and in The pattern of New Zealand culture noted that Perkins was implicated in its importation (p. 181). Tomory believed any artistic concept that was adopted unaltered from another culture could not contribute to the development of a New Zealand style. He expresses this opinion in Landfall, in relation both to the importation of British neo-romanticism and modernist primitivism, and also in Distance, where he acknowledged that while New Zealand's remoteness may make borrowing a necessity, all borrowings must be adapted: 'although the personification of natural forms is characteristic of English romantic attitudes, it is not so in New Zealand' (p. 74).

${ }^{185}$ Lummis, 'Dennis Tumer in context' (1996), fn. 49, p. 118.

${ }^{186}$ David Mellors, 'A British chronicle: a chronology of neo-romantic art and culture 1935-55', in $A$ paradise lost: the neo-romantic imagination in Britain 1935-55, London: Lund Humphres in association with the Barbican Art Gallery, 1987, p. 11.

${ }_{187}$ Iain Buchanan, 'Frances Hodgkins and neo-romanticism' in James Ross, Linda Gill and Stuart McRae (eds.), Writing a new country: a collection of essays presented to E.H. McCormick in his 88th year. Auckland: J. Ross, 1993, p. 156.

${ }_{188}$ Kenneth Clark. 'The new romanticism in British painting', Art News, February 1947, pp. 24-29, 56-58. Hereafter abbreviated as Clark. 'The new romanticism in British painting' (1947).
} 
Clark considered to have been 'blind to certain values inherent in English art', he wrote:

\begin{abstract}
Now the English are a literary and a poetical people, and to cut out of English painting anything which can be described as literary is seriously to impoverish it. Yet this is what Roger Fry, in reaction against the trivial anecdotalism of the Royal Academy, felt bound to do. He thus cut off English painting from one of its most fruitful traditions, that to which belonged Blake, Turner and Samuel Palmer... These are the three native painters who have inspired the group of younger British artists whom 1 have called the New Romantics. I must, however, immediately dispel the idea that these artists look back wistfully on the past, like the Gothic revival; on the contrary, they have all been deeply influenced by Picasso, and nearly all have at one time or another worked in an abstract style. They are romantic only in the sense that they allow their visions of nature to be coloured by associations, and that they are often inspired by those mysterious, solemn or arresting aspects of nature which inspired the romantic poets. ${ }^{189}$
\end{abstract}

The heavily literary style was, as Frances Spalding puts it, a movement 'fuelled by nostalgia and inclined towards the melodramatic [but which] provided an appropriate style for wartime subjects' ${ }^{\prime}{ }^{190}$ After the Second World War the neo-romantic movement, with its nostalgic and literary aspects, lost most of its prestige. As David Mellors writes, the movement was 'first discredited by the cool sneers of Pop Art critics ... and then destroyed by the tide of formalism and the impact of American Abstract Expressionism.'191 By the time that Tomory left England neo-romanticism had become unfashionable. In his article, Clark had identified the dangers that the new romanticism faced. His description of one of these - the peril of 'linear decoration' - is remarkably similar to Tomory's comments on New Zealand neo-romanticism:

\footnotetext{
${ }^{184}$ Ibid., pp. 25-26.

${ }^{190}$ Frances Spalding, British art since 1900, London: Thames and Hudson, 1986, pp. 133-4.

${ }^{191}$ David Mellors, 'Preface' in A paradise lost. the neo-romantic imagination in Britain 1935-55, London: Lund Humphries in association with the Barbican Art Gallery, 1987, p. 9
} 
But romantic art, being basically organic, must spring from absorption in nature: and when it aims too directly at picture-making it becomes merely decorative. So the imitators of Sutherland who use his properties-the roots of twisted trees, for example-without having experienced them as expressive elements in nature, soon degrade them to hieroglyphs, with about as much significance as a cloud pattern on a Chinese pot. ${ }^{192}$

Tomory's criticism of the New Zealand adaptation of the movement is therefore consistent with the critical attitude in Britain at the time he left.

Pound sees the ideas about illustration that Tomory expressed in his Landfall essay as being fulfilled in his contribution to Distance looks our way. 'Several years later,' Pound writes, 'from the vantage point of the new canon his views and his position of institutional power had helped to achieve, Tomory is confident enough to name some artists' names'. ${ }^{193}$ Pound then quotes the following extract from Tomory's essay:

The writer and the poet tend to look for illustrations to their work. Thus they will tend to admire the artists in whose work they can find some literary element and will dismiss those who are purely painterly. This would not matter so much if New Zealand at the same time had a perceptive audience for the visual arts, but it had not ... the writers and the poets did a double shift as art critics. They delivered themselves of some well written misinterpretations because, in their new-found confidence, they were unaware that they were ignorant in the main of the art of painting. ... Therefore it was not difficult for the writers and poets to go astray, not so much in whom they selected but in whom they ignored. Subject painters like Eric Lee-Johnson and Russell Clark, with their realistic drawing, their romantic colour and their choice of significant subjects were quickly admired. ... But the image makers like Rita Angus and M.T. Woollaston failed to generate the same enthusiasm. ${ }^{194}$

\footnotetext{
${ }^{102}$ Clark, 'The new romanticism in British painting' (1947), p. 57.

${ }_{193}$ Pound, Headlands (1992), p. 191.

${ }^{194}$ Tomory, Distance (1961), pp. 73-74. Pound's ellipses.
} 
This is the end of the argument for Pound. He concludes: 'So one of the first canons of twentieth-century New Zealand painting, that of the "old colonial house and dead tree school", with Lee-Johnson confirmed as its head master by a monograph in 1956, is no sooner decided upon by the literati than it begins in 1958 aggressively to be undone by a museum professional, Peter Tomory.' ${ }^{195}$ However, it is important to recognise that Tomory assigned 'subject painters' like Clark and Lee-Johnson a specific role in the history of New Zealand art. Tomory felt these painters contributed little to the development of the modern movement, but acknowledged nonetheless the role the neo-romantic school had played in raising the awareness of painting as an art form in New Zealand. ${ }^{196} \mathrm{He}$ also credited this school with the creation of a 'popular symbology of New Zealandisms', which the 'image makers' would later convert into the 'feeling' works that Tomory sought. ${ }^{197}$

For Pound, the similarities between the literary critics and the new museum professionals are as important as the differences:

That this new generation are museum professionals, and that the old generation are mostly literary people, is less important, perhaps, than the differences in their critical concerns. Both share the concern that there be a national style, both call for it to be one of harsh clarity, and both assume it will be figurative (abstraction is still out of the question) but for the new critics, the old canon was too literary, too illustrative, too lacking in formal interest. ${ }^{198}$

In 1985 Tomory described how he saw the vision of New Zealand art put forward by literary-minded writers as something that had to be overcome in order for contemporary art to progress. This is perhaps why he was so critical of

\footnotetext{
${ }^{105}$ Pound, Headlands (1992), p. 192.

196 Tomory, Distance (1961), p. 74.

197 Tomory, Pattern (1968), p. 181.

198 Pound, Headlands (1992), p. 192. Pound's emphasis.
} 
these writers' efforts. While Tomory notes that these writers were doing 'doubletime' as art critics in the absence of anyone better qualified for the task, neither he nor Pound acknowledge that some of these writers openly admitted their limitations, and added caveats to their art criticism.

McCormick, for example, (singled out by Pound as one of the most influential voices of the literati) was one writer who acknowledged his limitations as a writer on art. In the Lee-Johnson monograph McCormick opened what is clearly termed a 'biographical introduction' with a disclaimer:

I am not attempting here in any real sense an estimate of Lee-Johnson's achievement as a painter. I am content to resign that task to qualified critics or ... leave it to posterity. ${ }^{199}$

Compare this to his earlier disclaimer in Letters and Art in New Zealand:

The terms used in the discussion of graphic art ... are a 'literary' observer's, not those of an artist or critic of art; for this reason the sections on art may be best regarded as pendants to the larger literary undertaking. ${ }^{200}$

Gordon H. Brown has noted that Landfall to some extent stopped the gap left when the Arts Year Book ceased publication in 1951, and in this way the journal became the most important forum for art criticism in New Zealand. Yet as Wystan Curnow observed in 1963, Landfall contributors (of whom he was one) were not trained for the role they had assumed:

Our art criticism remains, by and large, the hobby of versatile poets, journalists, historians and literary critics; in other words, of people whose training and practice is primarily to do with another thing. ${ }^{201}$

\footnotetext{
${ }^{199}$ McCormick, Eric Lee-Johnson (1956), p. 1.

${ }^{200}$ E.H. McCormick, Letters and art in New Zealand, Wellington: Department of Internal Affairs, 1940 , preface.

201 Wystan Curnow, 'Auckland Gallery lectures', Landfall, vol. 17, no. 2, June 1963, p. 196.
} 
Such statements indicate that these writers did not necessarily claim for themselves the authority on artistic matters that others have attributed to them. While Tomory's (and Pound's) observations about the affinity between literary critics and literary art are well grounded, Tomory also understood that 'proselytising' was a necessary component of promoting contemporary art in New Zealand in the late 1950s. ${ }^{202}$ The literary critics and the fondness shown in the art market for the works of 'sentimental' painters like Goldie and Lindauer were for Tomory the biggest obstacles to creating an appreciation for modern art, and his writing on art critics and sentimental painting discourages the reader from taking either seriously. Tomory's polemic was purposeful; as he told Kirker in 1985; 'I wrote something pretty hard about [Goldie and Lindauer] and that was what you had to do in those days - I found that in Britain - I mean you really had to be very tough and of course you made enemies. ${ }^{203}$

Tomory's proselytising appears to have some impact. In a 1963 letter to Woollaston, Ron O'Reilly discusses a recent review of Woollaston's work by Wystan Curnow, which appears to have puzzled or upset Woollaston:

I didn't think his point about Shelley was meant to be derogatory of S. or your taste in liking him but rather that he as an artist is a rather different proposition from Cézanne, so that the link between these two affinities of yours requires more explaining. Even though this could be argued it seems to say something-perhaps however rather more about Curnow whose pose is that of Tomory's art critic who is not (or not primarily) a literary critic, as against us literary gents..$^{2114}$

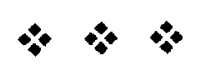

\footnotetext{
$2 n 2$ As Tomory said in 1985, 'At some stage, such as the late 'fifties, we had to proselytize a great deal about establishing a New Zealand contemporary art'. Kirker. Art New Zealand 41 (1986-87), p. 76.

${ }_{203}$ Kirker interview, Te Papa version, part 1.

${ }^{204}$ Ron O'Reilly, letter to Toss Woollaston, 10 July 1963. Museum of New Zealand Te Papa Tongarewa Archives, CA000457/3 Box 4 Item 3.
} 
Tomory's history of New Zealand art sought to define a line of artistic descent over the century of European settlement in this country by way of artists who developed styles that allowed them to convey a feeling response to the New Zealand landscape. His history eschewed those artists who he believed employed styles or conventions inappropriate to this effort. Despite this, his narrative allowed artists, such as Angus and Woollaston, to be connected to or understood in terms of international movements. Tomory emphasised the need to develop a style suitable to communicating the nature of New Zealand, but it is important to note that he did not argue for or attempt to define a single, 'national' style. As his discussion of the work of McCahon, Angus and Woollaston reveals, Tomory's use of Lipps' theory enabled him to easily encompass different stylistic approaches to the depiction of New Zealand in his history.

In Tomory's history a number of artists, movements, and periods (for example, Eric Lee-Johnson, late-19th-century history painting and the years 1905 to 1930) are treated as generally unprofitable offshoots from the central progress towards modern New Zealand art. His writing on art produced since the mid1950s shows little attempt to group or analyse contemporary painting; Tomory seems content to remark that artists were now (to use an anachronistic term) responding to an increasingly globalised world, and observe that contemporary art was lively and diverse. This is consistent with Tomory's art-historical attitude. It is the task of the art historian, working with the benefit of critical distance, to trace patterns and trends, while it is the task of the critic to explicate contemporary practice. And while Tomory lobbied passionately for more professional, better-informed art criticism, he did not identify himself as a critic.

The impact of Tomory's formulation of a history of New Zealand art, both at the time and in subsequent reincarnations and revisions, is undeniable. It is 
unfair however-unfair to Tomory, and unfair to other figures in this period-to treat him as simply one of a group of commentators homogenised by the epithet 'nationalist writers'. While his thinking bears similarity to those who went before him, and those who succeeded him, it is also strongly individual and at times even idiosyncratic. Indeed, if this study has achieved anything, it reveals that the period from the mid 1950s to the late 1960s was both more and less than it has been portrayed in later criticisms. It was more diverse, more complex, more debated; but less dogmatic, less insular, and decidedly less 'nationalistic'. 


\section{Conclusion}

I always intended, wherever I went, to build up the best thing I could. ${ }^{1}$

Looking back, Tomory saw his time in Auckland as his most fruitful in terms of achieving for an institution an 'extraordinary influence and general breakthrough'.2 Tomory left the Gallery in late 1964, for a lectureship in art history at the University of Auckland School of Arts; he had previously taught part-time at the University, between Fairburn's death in 1957 and the appointment of Kurt von Meier in 1963. In 1968 he left Auckland for New York, to an appointment as associate professor in art history at Columbia University. ${ }^{3}$ After two years at Columbia Tomory moved to Florida and the Ringling Museum of Art in Sarasota, where he was chief curator for two years, working with the Museum's significant baroque collection.

Tomory's final professional appointment came in 1973, when he became head of Art History at La Trobe University, Melbourne, where he was given the opportunity to build a new department from scratch. Tomory said in 1985 that he still firmly believed that art history was not a bread-and-butter subject, and that the majority of graduates would not pursue a career in the field; the best possible outcome, he believed, was the creation of a highly informed public able to appreciate and support the arts. ${ }^{4}$ This strongly reflects his attitude as director in Auckland, where he felt the Gallery's core role was to build up a discerning

\footnotetext{
${ }^{1}$ Kirker interview, Te Papa version, part 2.

${ }^{2}$ Ibid.

In an interview with Robert Leonard and Wystan Curnow, Jim Allen remembered seeing Tomory at Columbia soon after the 1968 student riots: 'Peter Tomory was teaching at Columbia. Well, he was taking his classes in the park under the trees. The blood was still being washed from the steps of the University following the suppression of the recent student strike. Most of the University staff remained locked in their rooms but Peter had elected to continue outdoors.' Wystan Curnow and Robert Leonard, 'Contact: Jim Allen talks to Wystan Curnow and Robert Leonard'. Art New Zealand 95, Winter 2000, p. 51.

${ }^{4}$ Kirker interview, Te Papa version, part 2.
} 
audience for the visual arts. Tomory retired from La Trobe in 1987, at which time he was made an Emeritus Professor. In 1992 he returned to Britain, settling in Dorset, where he lives now. He continues to publish, and in 1997 produced with Anne Kirker the summary catalogue British painting, 1800-1990, in Australian and New Zealand public collections.

An evaluation of Tomory's strengths and weaknesses as director of the Auckland City Art Gallery could be made using his own criteria. This extract was cited in the discussion of Tomory's initial vision for the Gallery:

Our main concern must be for the public and not for the artist, for true and lasting support for the artist must come from the patronage of the public and not from the Art Gallery. No cultured civilisation has yet owed its existence to an art gallery. This is not to deny the position of the Gallery in the cultural life of a city. It plays, or must play, the part of the preserver of standards and the authority in visual arts matters. Its collections and exhibitions must provide a comprehensive view of all periods of art which will interest and inform the public and stimulate the artist. In fact the heir to the well endowed private patron of the past is the art gallery. It must therefore be well informed so that its authority is unquestioned. It must be well-endowed with works for all to see. It must be host and mentor to the public and artists of serious intent. It must be quick to quash the second rate and resist with all its might any attempt to undermine its prestige and weaken its authority. The Gallery must never become the unprotected king on the board of local art politics, nor the Hyde Park of every art orator. For the Gallery has a serious duty to perform and it must be allowed to perform this duty under the care of its professional staff and to follow a policy which will bring with it increasing respect and importance..$^{5}$

Tomory believed that the Gallery should primarily concern itself with the education of the public. To this end he consolidated the Gallery's collection in order to, as he wrote, 'provide a comprehensive view of all periods of art which will interest and inform the public and stimulate the artist.' The Italian collection, the print collection and the collection of modernist sculpture still bear

\footnotetext{
5'Auckland City Art Gallery Director's Report April 1956'. p. I.
} 
his mark. Through the Gallery's exhibition programme-particularly the touring shows-audiences around the country were exposed to international and local art from all periods, including challenging contemporary work.

Tomory felt it was not the Gallery's role to be at the forefront of contemporary art but rather, as he noted, to be 'the preserver of standards and the authority in visual arts matters'. For this reason, the Gallery must be 'well informed so that its authority is unquestioned'; the emphasis placed upon scholarship at the Gallery is evidenced by the careful research into and accurate cataloguing of the permanent collection, and the Gallery's impressive publishing record. Tomory felt the Gallery had to be 'quick to quash the second rate and resist with all its might any attempt to undermine its prestige and weaken its authority'; this statement accords with his opposition to both the Kelliher Prize exhibition and the imposition of an advisory committee. To exercise such authority the Gallery's own professionalism had to be indisputable, and Tomory's emphasis upon staff training can also be seen in this context. Building on the foundations laid by Westbrook, Tomory firmly established the Gallery as New Zealand's leading authority on the visual arts. As Hamish Keith observed, when asked what he thought to be the Gallery's greatest achievements at this time:

Its professionalism and its ability to maintain itself with a minimum of public scandal. ... I think that was good management, we didn't invite controversy but that didn't mean to say we didn't avoid it either ... you always had a feeling with the Gallery that it was serious, you didn't have the feeling that you were being duped or somebody was experimenting on you. ${ }^{6}$

\footnotetext{
${ }^{6}$ Hamish Keith, personal communication to the author, 9 February 2004.
} 
Tomory's emphasis upon professionalism characterises his tenure. If, however, one were to seek Tomory's weakness, one could find it in his somewhat circumscribed approach to New Zealand art. He consistently placed greater emphasis on the international collection than the New Zealand collection. His writing on New Zealand art seems most fluent he discusses style, rather than subject or content. Although abstract artists were shown at the Gallery, their work was only discussed in passing in his writing. Tomory's dismissal of the neo-romantic school of painting in New Zealand has had long-lasting consequences for the appreciation of artists such as Eric Lee-Johnson and Russell Clark. Yet the Gallery undoubtedly advanced the cause of New Zealand art. In the absence of a network of dealer galleries, it provided a high-profile space allowing contemporary artists who did not fit with the attitudes of traditional art societies to show work publicly. Touring exhibitions of contemporary New Zealand art gave audiences the opportunity to see recent painting and sculpture. Shows of historical New Zealand art reinforced the emerging sense of a history of artistic practice in this country, and exhibitions such as Painting from the Pacific aligned New Zealand art with international contemporary art for the first time.

Tomory brought with him the knowledge, contacts and attitudes he developed at Edinburgh University, in provincial art galleries, and with the Arts Council of Great Britain. On his departure from New Zealand he left behind not only a model of professional museum practice, but also a well-defined history of New Zealand art. Tomory's writing has often been employed by critics in attempts to expose the tropes of nationalist art history - of the hard clear light, of the unique New Zealand landscape, of the vitriolic rejection of modernist art and internationalism - but a close study of Tomory's writing reveals the danger of creating a category such as 'nationalist writers', or even the 'nationalist period'. While Tomory's writing certainly reflects the contemporary concern with 
defining a New Zealand identity, his attitude towards the possibility of, or need for, a national school of painting had become lukewarm by the early 1960 s. Tomory's opinions reflected current British thinking, and his history was underpinned by a subtle understanding of the relationship between visual environment, perception and art, built on ideas drawn from German aesthetic theory. Tomory's emphasis on the emergence of a new generation of artists that was concerned primarily with the urban experience undermines the characterisation of nationalist writers as 'pro-rural' and 'anti-urban'.

Tomory's twelve years in New Zealand intersected with a period of rapid growth in the arts infrastructure. By the end of the 1960s, professional practices were being followed by trained staff in New Zealand's public art galleries, and a dealer gallery scene had emerged. Contemporary art was more widely shown and accepted, art criticism was flourishing, artists were on the brink of being able to make a living from art-making, and a sense of New Zealand's artistic history was well established. In all these developments we can trace the influence of Peter Tomory. 


\section{i Unpublished sources}

Ambler, F.N., 'Kelliher Art Exhibition: Points in favour of it being shown in the Auckland Art Gallery', undated report tabled at an Auckland City Council meeting c. early 1964, AAG archives.

Brown, Gordon H., interview with Colin McCahon, 14 March 1979, Alexander Turnbull Library Manuscripts and Archives Collection, MS-Papers-2019.

Brown, Gordon H., letter to Courtney Johnston, 19 January 2004.

Brown, Maria, 'The history and function of the Auckland City Art Gallery in the construction of a canon of modernist New Zealand art', unpublished MA thesis, University of Auckland, 1999.

Cochran, Chris, 'Cultural heritage assessment of the Sarjeant Gallery', Wanganui, 1998.

Dunn, Michael, letter to Laurence Simmons and James Ross, editors of Order and Intuition. Museum of New Zealand Archives Te Papa Tongarewa Archives. Gordon Walters papers, General Correspondence, Folder 12 CA00030 MS Papers 90.

Fairburn, A.R.D., 'Control of the Auckland City Art Gallery', letter to the Auckland City Council, 14 August 1955, Alexander Turnbull Library Manuscripts and Archives Collection, MS-Papers-1128-099.

Johnston, Courtney, interview with Hamish Keith, 9 February 2004.

Kirker, Anne, interview with Peter Tomory 25 December 1985. Museum of New Zealand Te Papa Tongarewa Archives, MU466/12 [40] 1985/2 P Tomory.

Kirker, Anne, interview with Peter Tomory 25 December 1985. Museum of New Zealand Te Papa Tongarewa Archives, MU466/12 [41] 1985/2. P Tomory.

Lee-Johnson, Eric; Eric Lee-Johnson collection, 'Correspondence and papers relating to art and photography'. Alexander Turnbull Library Manuscripts and Archives Collection, MS-Papers-5437-135. 
Lummis, Richard, 'Dennis Turner in context', unpublished MA thesis, University of Auckland, 1998.

McCahon, Colin, letter to Ron O'Reilly, 19 March 1956, private collection.

McCahon, Colin, letter to Ron O'Reilly, October 1957, private collection.

McCahon, Colin, letter to Ron O'Reilly, late October 1957, private collection

Minutes of the Parks and Library Committee, 31 October 1960, ACC archives.

Minutes of the Parks and Library Committee meeting, 5 August 1963, AAG archives.

O'Reilly, Ron, letter to Toss Woollaston, 10 July 1963. Museum of New Zealand Te Papa Tongarewa Archives, CA000457/3 Box 4 Item 3.

Shand, Peter, 'Adrift on an ocean of affinities: modernist primitivism and the Pacific 1891-1984', unpublished PhD thesis, University of Auckland, 1998.

Skinner, Damian, interview with Michael Scholes, 7 February 2000. Rotorua Oral History Project, Museum of New Zealand Te Papa Tongarewa Archives.

Tomory, Peter, 'Auckland City Art Gallery director's report April 1956', presented to the Parks and Library Committee 3 May 1956, ACC Archives.

Tomory, Peter, letter to Jackwood Palmer, 20 March 1956, AAG archives.

Tomory, Peter, letter to Joanna Drew, 21 March 1956, AAG archives.

Tomory, Peter, letter to E.K. Waterhouse, 23 April 1956, AAG archives.

Tomory, Peter, letter to E.K. Waterhouse, 29 August 1956, AAG archives.

Tomory, Peter, letter to E.K. Waterhouse, 4 December 1956, AAG archives.

Tomory, Peter, letter to the Auckland Town Clerk, 1 February 1960, AAG archives. 
Tomory, Peter, letter to F.N. Ambler, 1 April 1960, AAG archives.

Tomory, Peter, letter to Nikolaus Pevsner, 18 October 1960, AAG archives.

Tomory, Peter, cable to Auckland City Art Gallery staff, 8 December 1960, AAG archives.

Tomory, Peter, 'Purchases Advisory Committee', memorandum to the Auckland Town Clerk, 1 August 1963, ACC archives.

Tomory, Peter, report to the Auckland City Council, 10 March 1964, AAG archives.

Tomory, Peter, draft of a short text for the 1988 history of the Auckland City Art Gallery, dated 11 May 1987, AAG Archives.

Turner, Dennis Knight, letter to Peter Tomory, 16 January 1957, AAG archives.

Webb, Peter, letter to Courtney Johnston, 10 February 2004. 


\section{ii Peter Tomory's published writings}

Tomory, Peter, Festival of Britain: masterpieces from Yorkshire houses, York, 1951.

Murillo: a Spanish painter, London: The Medici Society, 1954.

The Ellesmere collection of old master drawings, Leicester: Leicester

Museums and Art Gallery, 1954.

New Zealand painting: an exhibition arranged by the Auckland City Art

Gallery and the Auckland Society of Arts on the occasion of the 1956 Auckland Festival of the Arts, Auckland: Auckland City Art Gallery, 1956.

'Drawings by Josef Herman', Home and Building, vol. 19, no. 2, July 1956, pp. $44-47$.

'Henry Moore stirred public profoundly', Star, 4 October 1956, p. 4.

"“The kitchen sink group"', Home and Building, vol. 19, no. 7, December 1956, pp. 40-45.

'An Arts Council for New Zealand?', Home and Building, vol. 19, no. 8, January 1957, pp. 9, 76.

'Contemporary Australian painters', Home and Building, vol. 19, no. 10, March 1957, pp. 42-43.

, 'Old master prints', Home and Building, vol. 19, no. 12, May 1957, pp. 4445.

Mantegna, London: The Medici Society, 1958.

'XXth century French painting', Home and Building, vol. 20, no. 6,

November 1958, pp. 44-45.

'Looking at art in New Zealand', Landfall 46, vol. 2, no. 2, 1958, pp. 153169. 
'The Art Gallery moves to its goal', newspaper clipping from the AAG archive, not dated or sourced, c. late 1958.

Goya, London: The Medici Society, 1959.

'Introduction' in Old Master paintings from the private and public collections of New Zealand, Auckland: Auckland City Art Gallery, 1959, pp. 4-5.

Petrus van der Velden: paintings 1870-1912, Auckland: Pelorus Press, 1959.

'Unifying art-in New Zealand', Connoisseur, May 1959, pp. 9-11.

'Resentment emotional' - gallery director', Star, 3 July 1958, p. 8.

'Difficult year for Gallery', NZH, 12 December 1959, p. 26.

Review of Bernard Smith, European vision and the South Pacific, 1768-1850

[1960], Journal of the Polynesian Society, vol. 69, 1960, pp. 415-417.

'Presidential address by P.A. Tomory', AGMANZ newsletter, no. 9, May 1960, pp. 4-6.

'A gallery's reputation is built on that of its collections', Star, 20

September 1960, p. 4.

Letter to the Editor, NZH, 22 September 1960, p. 4.

'A national colonial museum', Northland: a regional magazine, no. 12, October 1960, pp. 24-25.

Letter to the Editor, NZH, 11 October 1960, p. 4.

'The visual arts' in Sinclair, Keith (ed.), Distance looks our way: the effects of remoteness on New Zealand, Auckland: Paul's Book Arcade for the University of Auckland, 1961, pp. 63-78.

(ed.), Painting from the Pacific, Auckland: Auckland City Art Gallery, 1961. 
'Josef Herman Three Miners Resting and Miners' Canteen', Auckland City Art Gallery Quarterly, no. 17, 1961, pp. 2-3.

'Art market is tough and competitive', newspaper clipping from the AAG archives, not dated or sourced, c. early 1961.

'Contemporary art meets with similar problems everywhere', Star, 6 April 1961, p. 4.

'Jacob Epstein drawings and sculpture', Home and Building, vol. 23, no.

12, May 1961, pp. 58-59, 93-95.

'Painting in the Pacific', Home and Building, vol. 24, no. 2, July 1961, pp. 56-59.

'Juan de Juanes (attributed) Saint Sebastian and Saint Catherine of Alexandria', Auckland City Art Gallery Quarterly, no. 23, 1962, p. 6.

'J.M.W. Turner Westminster Abbey from Saint James' Park and Horseguards Parade, Whitehall', Auckland City Art Gallery Quarterly, no. 23, 1962, p. 7.

'Galleries, museums and the government: an address by the president, Mr. P.A. Tomory to members at the Annual Meeting at Dominion Museum on 28th March, 1962', AGMANZ newsletter, no. 13, May 1962, pp. 1-3.

'Petrus Van der Velden River Landscape', Auckland City Art Gallery Quarterly, no. 25, 1963, p. 2.

'Jannis Spyropoulos Themes and Variations', Auckland City Art Gallery Quarterly, no. 26, 1963, pp. 3-4.

'Sir Peter Lely (studio) Portrait of Oliver Cromwell', Auckland City Art Gallery Quarterly, no. 27, 1963, p. 2.

'Agostino Carracci Design for a cartouche and head studies', Auckland City Art Gallery Quarterly, no. 27, 1963, p. 7.

'Barbara Hepworth Torso II (Torcello)', Auckland City Art Gallery

Quarterly, no. 28, 1963, pp. 2-3. 
'Sculpture in France', Home and Building, vol. 26, no. 6, November 1963, pp. $44-46$.

Contemporary painting in New Zealand, Wellington: Queen Elizabeth II Arts Council of New Zealand, 1964.

A summary catalogue of paintings, drawings and sculpture, Auckland:

Auckland City Art Gallery, 1964.

'Francisco Goya A Crowd Hamstrings a Bull and A Spanish Horseman

Lances the Bull', Auckland City Art Gallery Quarterly, no. 29, 1964, pp. 2-3.

,'Salvator Rosa A Rocky River Landscape with Figures, Giovanni Francesco Grimaldi Two Men on a Hilltop, Giovanni Battista Tiepolo A Woman with her Hands Resting on a Vase', Auckland City Art Gallery Quarterly, no. 29, 1964, pp. 6-7.

'Alexandre Archipenko Gondolier', Auckland City Art Gallery Quarterly, no. 30,1964 , pp. 4-5.

'George Michel Windmill in a Landscape' Auckland City Art Gallery

Quarterly, no. 30, 1964, p. 6.

, 'Colin McCahon Here I Give Thanks to Mondrian', Auckland City Art Gallery Quarterly, no. 31, 1964, pp. 6-7.

'Dirck Santvoort Portrait of a Lady', Auckland City Art Gallery Quarterly, no. 32,1964 , pp. 2-3.

'Willem van de Velde A Harbour Scene with a State Barge', Auckland City Art Gallery Quarterly, no. 32, 1964, p. 5.

'Count Hendrik Goudt Tobias and the Angel', Auckland City Art Gallery Quarterly, no. 32, 1964, pp. 6-7.

'Cornelius Cort Diana and Callisto', Auckland City Art Gallery Quarterly, no. 32,1964 , p. 7. 
'What's different about New Zealand art?', Listener, October 30, 1964, pp. 3, 22.

'It started in the thirties', Listener, 6 November 1964, pp. 5, 21.

'Art can't be taught', Listener, 20 November 1964, p. 3.

Letter to the Editor, Listener, 4 December 1964, p. 10.

A collection of drawings by Henry Fuseli, Auckland: Auckland City Art Gallery, 1967.

Gauguin-French School, London: The Medici Society, 1968.

(ed.), Painting 1827-1967, Wellington: A.H. \& A.W. Reed, 1968.

'Art' in McLeod, A.L. (ed.), The pattern of New Zealand culture, Melbourne and New York: Oxford University Press and Cornell University Press, 1968, pp. 176-208.

'Imaginary reefs and floating islands: the romantic image in New

Zealand painting', Ascent, vol. 1, no. 2, July 1968, pp. 5-19.

Letter to the Editor, Ascent, vol. 1, no. 4, November 1969, p. 74.

Foundations of European art, London: Thames \& Hudson, 1969.

The Bick collection of Italian religious drawings, Sarasota: John and Mable Ringling Museum of Art, 1971.

'Introduction' in Salvator Rosa: his etchings and engravings after his works, Sarasota: John and Mable Ringling Museum of Art, 1971.

The life and art of Henry Fuseli, London: Thames and Hudson, 1972.

Art history past and present, Bundoora, Victoria: La Trobe University, 1973.

(ed.), The role and constitution of Australian art museums, Bundoora,

Victoria: Art Association of Australia, 1976. 
'Three oaths for Gavin Hamilton', Australian Journal of Art I, 1978, pp. 59-64.

The poetical circle: Fuseli and the British, Florence: Centro Di and Australian Gallery Directors' Council, 1979.

'Salvator Rosa: La Menzogna', Paragone XXXI, September 1980, pp. 60-66.

'Cleopatra, pearls and extravagance: Tiepolo's Banquet of Cleopatra', Art Bulletin of Victoria 22, 1982, pp. 4-11.

Old master drawings from the national collection, Wellington: National Art Gallery, 1983.

'Eighteenth-century Italian paintings', Apollo CXVIII, December 1983, pp. $476-485$.

Black and white: an excursion through the media and ideas, Auckland:

Friends of the Auckland City Art Gallery, 1985.

'The fortunes of Sappho: 1770-1850', in Clarke, G.W. (ed.), Rediscovering Hellenism: the Hellenic inheritance and the English imagination, Cambridge: Cambridge University Press, 1989.

'The Bridgehead revisited', Landfall, vol. 185, April 1993, pp. 15-16.

Tomory, Peter, N. Powell and R. Edwards, 'Horrific, macabre and erotic', Apollo, vol. 197, no. 136, 1973, pp. 619-621.

Tomory, Peter and Robert Gaston, European paintings before 1800 in Australian and New Zealand public collections: summary catalogue, Sydney: Beagle Press, 1989.

Tomory, Peter and Anne Kirker, British painting, 1800-1990, in Australian and New Zealand public collections, Sydney: Beagle Press in conjunction with the British Council, 1997. 


\section{Note to the bibliography}

While Tomory is likely to have written many more articles for the Auckland City Art Gallery Quarterly, which was one of his most important initiatives at the Gallery, only those entries which carry his initials have been cited here. The Quarterly was edited by different staff members between 1956 and 1964, and entries (which were not all attributed) were written by Tomory, Colin McCahon, Ross Fraser and Hamish Keith.

For the following catalogues published by the Auckland City Art Gallery, Tomory wrote forewords or brief introductory texts:

1956

An exhibition of drawings by four realist painters

Ecole de Paris

Josef Herman

1957

I. C. Richmond

Recent French graphic work

Rouault's 'Miserere'

J. C. Hoyte

British fine crafts

Costume and daily life in the drawings of three centuries

$X X$ th century French painting

Eight New Zealand painters

1958

Rembrandt: 69 etchings

Picasso: lithographs and aquatints

John Kinder

British abstract painting

A private collection of New Zealand paintings

A colonial view

Twentieth century sculpture (from the permanent collection)

Twentieth century British drawings 
Rowlandson

Eight New Zealand painters II

1959

Contemporary New Zealand drawings

Frances Hodgkins paintings and drawings

Colonial Auckland

James Preston

Petrus van der Velden

Eight New Zealand painters III

1960

Contemporary Australian Art

Old master prints from the Monrad collection

Los Caprichos

Modern European paintings in New Zealand

Prints from France

Contemporary Japanese woodcuts

Old master drawings from the Witt collection [with a historical note]

Contemporary New Zealand painting and sculpture

1961

Epstein

Landmarks in the history of medicine

The wars in New Zealand

International prints

Mina Arndt

Contemporary New Zealand painting 1961

1962

Nineteenth and Twentieth century French prints

Six New Zealand expatriates:

Art in Italy 1500-1800

British taste in the nineteenth century

Contemporary New Zealand painting and sculpture 
1963

A retrospective exhibition: M.T. Woollaston, Colin McCahon

Etchings of Piranesi

Sculpture in France

Contemporary New Zealand painting 1963

1964

Pablo Picasso: 102 linocuts

Three British painters

James Nairn and Edward Fristrom

Captain James Cook: his artists and draughtsmen

Contemporary New Zealand painting 


\section{iii General bibliography}

'Agreement will integrate Gallery's pictures', Star, 2 June 1956, p. 3.

AGMANZ newsletter, no. 8, February 1960.

Alpers, Antony, "No one-man shows' means no-one worthy of them', Star, 23 May 1957, p. 4.

Amoamo, Jacqueline, 'New Zealand painting in perspective', Listener, 29

December 1967, pp. 54-55.

Appleyard, Bryan, The culture club: crisis in the arts, London: Faber and Faber, 1984.

Arnason, H.H., A history of modern art: painting, sculpture, architecture, photography, 3rd edition, London: Thames and Hudson, [1969] 1988.

'Art advisory group sought', Star, 16 July 1963, p. 1.

'Art critics urged to be ruthless', Press, 5 October 1962, p. 14.

'Art gallery compares very well', Star, 7 March 1961, p. 3.

'Art Society will put case to Mayor', Star, 10 August 1955, p. 3.

'Auckland's director-to-be', Auckland Weekly News, 16 November 1955, p. 16.

Barr, Jim and Mary Barr, When art hits the headlines, Wellington: National Art Gallery, 1987.

Barrowman, Rachael, A popular vision: the arts and the left in New Zealand 19301950, Wellington: Victoria University Press, 1991.

Barton, Christina, Louise Henderson: the cubist years 1946-1958, Auckland: Auckland City Art Gallery, 1991. 
Behr, Shulamith, 'Dr Rosa Schapire: art historian and critic in exile', in 'Keine

Klage über England?', Proceedings of the Second International Symposium on German and Austrian Exile Research in Great Britain 1933-45, Brinson, C., R. Dove, A. Grenville, M. Malet and J. Taylor (eds.), Institute of Germanic Studies and Judicium Verlag, vol. 72, 1998, pp. 215-223.

Bell, Clive, Art, [1913] New York: Capricorn Books, 1958.

Bell, G.E., 'The arts in Wellington 1962', Home and Building, vol. 25, no. 5, February 1963, pp. 105-116.

'Australian painting of the XIXth and XXth century', Home and Building, vol. 27, no. 2, September 1964, pp. 61, 109-112.

Bell, Leonard, 'How far, how late, how lonely?' Listener, 1 December 1961, p. 39. 'Landfall, the 'primitive', and the visual arts in the 1950s', Landfall, vol. 185, April 1993, pp. 106-113.

Blackley, Roger, Goldie, Auckland: Auckland Art Gallery Toi o Tāmaki and David Bateman, 1997.

Bloem, Marja and Martin Browne, Colin McCahon: a question of faith, Nelson and Amsterdam: Craig Potton Publishing and the Stedelijk Museum Amsterdam, 2002.

Bogle, Andrew, and Brian Muir, The Mackelvie Collection: a centenary exhibition 1885-1985, Auckland: The Mackelvie Trust, Auckland City Art Gallery and Auckland Institute and Museum, 1985.

Bolster, Tom, 'Five New Zealand watercolourists', Home and Building, vol. 11, no. 8, January 1959, pp. 40-41, 80.

Brasch, Charles, 'Art gallery policy', Landfall 11, vol. 3, no. 3, September 1949, pp. 176-182.

'Round the galleries: Wellington', Landfall 30, vol. 8, no. 2, June 1954, pp. $127-129$. 
'Art galleries and the Arts Council', Ascent, vol. 1, no. 1, November 1967, pp. 24-25.

Review of Peter Tomory (ed.), Painting 1827-1967, Ascent, vol. 1, no. 3, April 1969, pp. 83-86.

Letter to the Editor, Ascent, vol. 1, no. 4, November 1969, pp. 74-75.

Brown, Gordon H., 'Editorial', Auckland City Art Gallery Quarterly, no. 40, 1968, p. 1.

'The visual arts' in Wards, Ian (ed.), Thirteen facets: essays to celebrate the Silver Jubilee of Queen Elizabeth the Second 1952-1977, Wellington:

Government Printer, 1978, pp. 317-334.

New Zealand painting 1940-1960: conformity and dissension, Wellington: Queen Elizabeth II Arts Council of New Zealand, 1981.

Colin McCahon: artist, Auckland: Reed, 1981.

Elements of modernism in Colin McCahon's early work, Wellington: Art History, Victoria University of Wellington, 2003.

Brown, Gordon $\mathrm{H}$. and Hamish Keith, 10 years of New Zealand painting in Auckland 1958-1967, Auckland: Auckland City Art Gallery, 1967.

An introduction to New Zealand painting 1839-1967, Auckland: Collins, 1969.

Brown, Maria, 'The public art gallery and the construction of a canon of modernist New Zealand art', paper presented at the conference of the Art Association of Australia and New Zealand, Victoria University of Wellington, 2-5 December 1999, published as Pre/dictions: the role of art at the end of the millennium, pp. 142-146.

Buchanan, Iain, 'Frances Hodgkins and neo-romanticism' in Ross, James, Linda Gill and Stuart McRae (eds.), Writing a new country: a collection of essays presented to E.H. McCormick in his 88th year, Auckland: James Ross, 1993, pp. 155-164. 
Butterworth, Susan, The Suter: one hundred years in Nelson, Nelson: Nikau Press, 1999.

Cape, Peter, New Zealand painting since 1960: a study in themes and developments, Auckland: Collins, 1979.

Clark, Kenneth, 'The new romanticism in British painting', Art News, February 1947, pp. 24-29, 56-58.

The study of the history of art, reprinted by The Bowering Press, Plymouth from Universities Quarterly, vol. X, no. 3, May 1956.

Clark, Nigel, "Imaginary reefs and floating islands': speculations on the digital refiguring of the Antipodes', Sites, no. 31, Spring 1995, pp. 1-30.

Cochran, Vita and Jill Trevelyan, Rita Angus: live to paint and paint to live, Auckland: Godwit/Random House in association with City Gallery Wellington and Hocken Library, Dunedin, 2001.

'Confidence motion proposed-Art Gallery director', NZH, 19 July 1963, p. 1.

'Cup of tea leads to art coup of a lifetime', NZH, 27 February 1965, section 3, p. 5.

Curnow, Allen, 'The Art Gallery controversy-A precedent to be avoided', NZH, 12 August 1955, p. 13.

Curnow, Wystan, 'Painting from the Pacific', Landfall, vol. 15, no. 3, September 1961, pp. 259-262.

'Auckland Gallery lectures', Landfall, vol. 17, no. 2, June 1963, pp. 196199.

'Sewing up the space between', Midwest 7, 1995, pp. 16-19.

Curnow, Wystan and Robert Leonard, 'Contact: Jim Allen talks to Wystan Curnow and Robert Leonard', Art New Zealand 95, Winter 2000, pp. 48-55, 99.

Duncan, Carol, Civilising rituals: inside public art museums, London and New York: Routledge, 1995. 
Duncan, Carol and Alan Wallach, 'Museum of Modern Art as late capitalist ritual: an iconographic analysis', Marxist Perspectives, Winter 1978, pp. 28-51.

Dunn, Michael, A concise history of New Zealand painting, Auckland: David Bateman, 1991.

Edmond, Lauris (ed.), The letters of A.R.D. Fairburn, Auckland: Oxford University Press, 1981.

Entwisle, Peter, Treasures of the Dunedin Public Art Gallery, Dunedin: Dunedin Public Art Gallery, 1990.

Fairburn, A.R.D., 'Literature and the arts' in Belshaw, Horace (ed.), New Zealand, Berkeley and Los Angeles: University of California Press, 1947.

'Art in Canterbury: some notes on the Group show', Landfall, 5, vol. 2, no. 1,1949 , pp. $49-50$.

'The culture industry' [1956] in Glover, Denis and Geoffrey Fairburn (eds.), A.R.D. Fairburn: The woman problem and other prose, Auckland: Blackwood and Janet Paul, 1967, pp. 136-152.

'Afterthoughts on an art exhibition', Home and Building, vol. 19, no. 3, August 1956, pp. 37, 72-73.

Fairburn, G.E., Letter to the Editor, Listener, 20 November 1964, p. 10. Letter to the Editor, Listener, 24 December 1964, p. 8.

Fraser, Ross, 'In search of New Zealand painting', Home and Building, vol. 20, no. 8 , January 1958, pp. 44-45, 69.

'The gallery's first eighty years', Quarterly of the Auckland City Art Gallery, no. 49, March 1971, pp. 15-19.

'Looking back: memories of painting in Auckland through the 1950s', Art New Zealand 66, Autumn 1993, p. 57. 
Fry, Roger, Vision and design, [1920] New York: Meridian Books, 1956.

'Gallery trying to avoid local 'art politics", Star, 17 May 1957, p. 5.

Gamble, Brenda, and Peter Shaw, Auckland City Art Gallery: a centennial history, Auckland: Auckland City Art Gallery, 1988.

Garland, Margaret, 'New Zealand painting in the National Gallery', Arts Yearbook 7, 1951, pp. 130-135.

Geraets, John, 'A second life-literary culture and Landfall in the 1950s', Landfall, vol. 185, April 1993, pp. 114-124.

Gilbert, Katherine Everett and Helmut Kuhn, A history of esthetics, [1953] New York: Dover Publications, 1972.

Gombrich, E.H, Art and illusion: a study in the psychology of pictorial representation, [1960] Oxford: Phaidon, 1991.

'On physiognomic perception', Daedalus 89, 1960, pp. 228-241.

Green, Tony, 'Peter Webb's Gallery', Bulletin of New Zealand Art History, vol. 1, 1972, pp. 12-24.

'McCahon's visit to the United States: a reading of letters and lecture notes', Bulletin of New Zealand Art History, vol. 3, 1975, pp. 19-42.

'Modernism and modernization', in Barr, Mary (ed.), Headlands: thinking through New Zealand art, Sydney: Museum of Contemporary Art, 1992, pp. 147-159.

'Making space', LOG Illustrated, issue 4, Winter 1998, p. 5.

Woollaston: origins and influence, Wellington: Art History, Victoria University of Wellington, 2004.

Greenberg, Clement, 'Is the French avant-garde overrated' [1953] in O'Brien, John (ed.), Clement Greenberg: the collected essays and criticism, vol. 3, Chicago and London: The University of Chicago Press, 1993, pp. 155-157. 
Grunenberg, Christoph, 'The politics of presentation: the Museum of Modern Art, New York', in Pointon, Marcia (ed.), Art apart: art institutions and ideology across England and North America, Manchester and New York: Manchester University Press, 1994, pp. 192-211.

Hall, David, Portrait of New Zealand, [1955] Wellington: A.H. \& A.W. Reed, 1966.

Harris, Jonathan, 'Cultured into crisis: the Arts Council of Great Britain', in Pointon, Marcia (ed.), Art apart: art institutions and ideology across England and North America, Manchester and New York: Manchester University Press, 1994, pp. 179-191.

Harrison, Charles, 'Modernism', in Nelson, Robert S. and Richard Schiff (eds.), Critical terms for art history, Chicago and London: The University of Chicago Press, 1996, pp. 142-155.

Hay, Daniel, Letter to the Editor, NZH, 24 August 1960, p. 8.

H.M., 'Other N.Z. artists deserve place in exhibition', Star, 19 October 1959, p. 6.

Hoffmann, Detlef, 'The German art museum and the history of the nation', in Sherman, Daniel J. and Irit Rogoff (eds.), Museum culture: histories, discourses, spectacles, Minneapolis: University of Minnesota Press, 1994.

Holcroft, M. H., Deepening stream: cultural influences in New Zealand, Christchurch: The Caxton Press, 1940. 1943.

The waiting hills, Wellington: The Progressive Publishing Company, Encircling seas: an essay, Christchurch: The Caxton Press, 1946.

'Hothouse of art interest: aim of new director', NZH, 6 April 1956, p. 13.

'How new director views art galleries' NZH, 6 March 1956, p. 13.

Johnston, Alexa, and Francis Pound, NZ XI, Auckland: Auckland City Art Gallery, 1988. 
Keith, Hamish, 'Patrick Hanly', Home and Building, vol. 25, no. 4, September 1962, pp. 60-61.

'Drawings from the West Coast of the U.S.A', Home and Building, vol. 25 , no. 5, October 1962, pp. 62-63, 111.

,Why buy works of art?', Home and Building, vol. 25, no. 6, November 1962, pp. 58-59, 83.

'Contemporary New Zealand Painting and Sculpture', Home and Building, vol. 25, no. 7, December 1962, pp. 48-49, 91-93.

Letter to the Editor, Listener, 4 December 1964, p. 10.

'Patrick Hanly: a conversation with Hamish Keith', Art New Zealand 14, 1979, pp. 45-51.

Letter to the Editor, Art New Zealand 101, Summer 2001-2002, p. 92.

Kelly, Mary, 'Re-viewing modernist criticism' in Wallis, Bryan (ed.), Art after modernism: rethinking representation, New York and Boston: The New Museum of Contemporary Art and David R. Godine, 1984, pp. 87-103.

Kenny, Nelson, 'Last show in "Eight New Zealand Painters" series the best', Press, 23 June 1960, p. 17.

'Woollaston dominates N.Z. painting exhibition', Press, 22 July 1960, p. 5 .

King, Richard, The Kelliher: 67 award winning paintings, Auckland: Orakau House. 1979.

Kirker, Anne, 'Peter Tomory's New Zealand years', Art New Zealand 40, Spring 1986, pp. 70-74.

Kirker, Anne, 'Peter Tomory's New Zealand years', Art New Zealand 41, Summer 1986-1987, pp. 75-78.

Lee-Johnson, Eric, Letter to the Editor, Listener, 11 December 1964, p. 10. 
Eric Lee-Johnson: no road to follow, Auckland: Godwit Press, 1994.

Leonard, Robert, 'The adventure that never was', Antic 2, March 1987, pp. 111119.

'Lindauers inferior says Mr Tomory', Star, 29 July 1960, p. 1.

Lipps, Theodor, 'Empathy and aesthetic pleasure' [1905] (trans. Karl Aschenbrenner) in Aschenbrenner, Karl and Arnold Isenberg (eds.), Aesthetic theories: studies in the philosophy of art, Englewood Cliffs, N.J.: Prentice-Hall Incorporated, 1965, pp. 403-412.

'Major purchases lift City Gallery standard', Star, 16 March 1961, p. 4.

'Mayor's response', NZH, 11 August 1955, p. 12.

Mane-Wheoki, Jonathan, 'Buck Nin and the origins of contemporary Maori art', Art New Zealand 82, Autumn 1997, pp. 61-65.

'Mayor's response', NZH, 11 August 1955, p. 12.

McCahon, Colin, Colin McCahon / a survey exhibition, Auckland: Auckland City Art Gallery, 1972.

McCormick, E.H., Letters and art in New Zealand, Wellington: Department of Internal Affairs, 1940.

Eric Lee-Johnson, Hamilton: Paul's Book Arcade, 1956.

Review of Bernard Smith's European vision and the South Pacific, 17281850 [1960], Landfall, vol. 15, no. 1, 1961, pp. 91-94.

McLeod, A.L. (ed.), The pattern of New Zealand culture, Melbourne and New York: Oxford University Press and Cornell University Press, 1968.

McLintock, A.H., 'Introduction' in National centennial exhibition of New Zealand art, Wellington: Department of Internal Affairs, 1940. 
Mellor, David (ed.), A paradise lost: the Neo-Romantic imagination in Britain 1935-55, London: Lund Humphries in association with the Barbican Art Gallery, 1987.

'More small art galleries: new director's advice', NZH, 28 March 1956, p. 13.

'Mr Gross says Board is 'not too happy', NZH, 10 August 1955, p. 12.

'Mr Tomory against advice procedure', Star, 19 July 1963, p. 3

Murray, Chris (ed.), Key writers on art: the twentieth century, London and New York: Routledge, 2003.

Murray, Stuart (ed.), Not on any map: essays in postcoloniality and cultural nationalisms, Exeter: University of Exeter Press, 1997.

Never a soul at home: New Zealand literary nationalism and the 1930s, Wellington: Victoria University Press, 1998.

National Art Gallery of New Zealand, A guide book to the National Art Gallery of New Zealand, Wellington, 1969.

'New gallery director has the right experience', Star, 8 March 1956, p. 4

'New director wastes no time', Star, 5 March 1956, p. 1

Nin, Buck and Baden Pere, New Zealand Maori culture and the contemporary scene, Christchurch, 1966.

'On world's art map', Weekly News, 22 July 1959, p. 22.

O'Reilly, Ron, Letter to the Editor, Landfall, vol. 15, no. 3, 1961, pp. 288-291.

'Paintings source of pleasure', NZH, 2 August 1956, p. 12.

Paton, Justin, Don Peebles: the harmony of opposites, Christchurch: Robert McDougall Art Gallery, 1996.

Paul, Janet, 'Introduction' in McCormick, E.H., Eric Lee-Johnson, Hamilton: Paul's Book Arcade, 1956, n.p. 
'Painting from the Pacific', Comment, vol. 3, no. 9, Spring 1961, pp. 910.

Petersen, G.C. (ed), Who's who in New Zealand [7th edition], Wellington: A.H. \& A.W. Reed, 1961.

Who's who in New Zealand [9th edition], Wellington: A.H. \& A.W. Reed, 1968.

Pick, John, Vile jelly: the birth, life and lingering death of the Arts Council of Great Britain, Doncaster: Brynmill, 1991.

Platts, Una, Nineteenth century New Zealand artists: a guide and handbook, Christchurch: Avon Fine Prints, 1980.

Porsolt, I.V., 'Gallery addition to festival: three painters exhibit', New Zealand Herald, 3 June 1959, p. 9.

'Eight artists seen in group show', New Zealand Herald, 19 October 1959 , p. 15.

'Recent British sculpture', Home and Building, vol. 25, no. 2, July 1962, pp. $62-63,103-107$.

'Festival exhibition of sculpture at Elam School of Art', Home and Building, vol. 26, no. 3, August 1963, pp. 52-53, 69.

'Piranesi etchings at the Auckland Art Gallery', Home and Building, vol. 26, no. 4, September 1963, pp. 52-53.

'New Zealand's Landfall-and mine', Landfall, vol. 185, April 1993, pp. 13-15.

Pound, Francis, Frames on the land: early landscape painting in New Zealand, Auckland: Collins, 1983.

'Harsh clarities: meteorological and geographical determinism in New Zealand art commentary refuted', Parallax, vol. 1, no. 3, Winter 1983, pp. 263-269. 
'Nationalist antitheses: a compendium', Antic 1, June 1986, pp. 73-84.

'The land, the light, and the nationalist myth in New Zealand art', in Philips, Jock (ed.), Te whenua, te iwi: the land and the people, Wellington: Allen \& Unwin and Port Nicholson Press, 1987, pp. 48-60.

'Walters and the canon' in Ross, James and Laurence Simmons (eds.) Gordon Walters: order and intuition, Auckland: Pelorus Print, 1989, pp. 5170.

'Silence, solitude, suffering, and the invention of New Zealand (A fictitious story)', Interstices, 1, 1991, pp. 61-83.

'Distance looks our way' in Distance looks our way: ten artists from New Zealand, The Trustees, Distance Looks Our Way Trust, 1991, pp. 21-30.

'The word and the art: New Zealand art criticism c. 1950-c. 1990' in Barr, Mary (ed.), Headlands: thinking through New Zealand art, Sydney: Museum of Contemporary Art, 1992, pp. 185-202.

'Emerging abstraction' in The 1950s show, Auckland: Auckland Art Gallery and New Zealand Home and Building, 1992, pp. 35-43.

'Painting and Landfall, and painting as literature's death', Landfall, vol. 185, April 1993, pp. 78-85.

The space between: Pakeha use of Maori motifs in modernist New Zealand art, Auckland: Workshop Press, 1994.

Stories we tell ourselves: the paintings of Richard Killeen, Auckland: Auckland Art Gallery Toi o Tämaki, 1999.

'McCahon, Mondrian and masking tape: a reading of the centre from the outermost edge', Journal of New Zealand Art History, vol. 23, 2002, pp. 11-20.

'A memory inhering in forms: new sources in the later paintings of Gordon Walters,' Art New Zealand 107, Winter 2003, pp. 71-77, 88-91. 
Preziosi, Donald, 'Collecting/museums' in Nelson, Robert S. and Richard Schiff (eds.), Critical terms for art history, Chicago and London: The University of Chicago Press, 1996, pp. 281-291.

Pringle, John Douglas, Australian painting today, London: Thames and Hudson, 1963.

Read, Herbert, The philosophy of modern art, [1952] New York: Meridian Books, 1957.

A concise history of modern painting, London: Thames and Hudson, 1959.

The forms of things unknown: essays towards an aesthetic philosophy, New York: Horizon Press, 1960.

Art now, [5th edition] London: Faber and Faber, 1968

Read, Herbert and T.E. Hulme, Speculations: essays on humanism and the philosophy of art, [2nd edition] London: Routledge and Kegan Paul, 1936.

Renshaw, Sue, 'We take a look at art in New Zealand: "It's in a healthy state" says art director', The New Zealand Woman's Weekly, 27 March 1961, pp. 1619.

Robert McDougall Art Gallery, The Canterbury Society of Arts 1880-1980, Christchurch: Robert McDougall Art Gallery, 1980.

Roberts, Julie, 'The role of the art museum: the Auckland City Art Gallery', Art New Zealand 65, Summer 1992-1993, pp. 72-74.

Roberts, Neil, The Robert McDougall Art Gallery: a profile of the Art Gallery of the city of Christchurch, Christchurch: Christchurch City Council, 1982.

Rothenstein, John, Summer's lease: autobiography 1901-1938, London: Hamish Hamilton, 1965.

'Sculpture decision short-sighted says Mr Tomory', NZH, 12 July 1963, p. 1. 
Simpson, E.C., A survey of the arts in New Zealand, Wellington: The Wellington Chamber Music Society, 1961.

Simpson, Peter, 'Ways to the museyroom: poetry anthologies in the fifties', Landfall, vol. 185, April 1993, pp. 95-105.

Sinclair, Andrew, Arts and cultures: the history of the 50 years of the Arts Council of Great Britain, London: Sinclair-Stevenson, 1995.

Sinclair, Keith (ed.), Distance looks our way: the effects of remoteness on New Zealand Auckland: University of Auckland, 1961.

A destiny apart: New Zealand's search for cultural identity, Wellington: Allen \& Unwin, 1986.

Skinner, Damian, Off the beaten track: modernism in Rotorua, Rotorua: Friends of Rotorua Museum of Art and History, 2000.

'Making modernism: Helen Stewart and the Wellington art scene 1946-1960', Art New Zealand 96, Spring 2000, pp. 102-106.

Don Binney: ngā manu/ ngā motu-birds/islands, Auckland: Auckland University Press, 2003.

Smith, Bernard, European vision and the South Pacific, 1768-1850, Oxford: Clarendon Press, 1960.

Spalding, Frances, British art since 1900, London: Thames and Hudson, 1986. Dance till the stars come down: a biography of John Minton, London: Hodder and Stoughton, 1991.

Taylor, Brandon, Art for the nation: exhibitions and the London public 1747-2001, Manchester: Manchester University Press, 1999.

Taylor, Robert, 'Tiki: the return of Dennis Knight Turner', Art New Zealand 67, Winter 1993, pp. 58-62.

Thistlewood, David, Herbert Read: formlessness and form, an introduction to his aesthetics, London: Routledge and Kegan Paul, 1984. 
Thomas, Nicholas, Possession: indigenous art / colonial culture, London: Thames and Hudson, 1999.

Tizard, R., The Auckland Society of Arts 1870-1970: a centennial history, Auckland: Auckland Society of Arts, 1970.

‘To examine advisory plan-Public packs Torso debate', NZH, 23 July 1963, p. 1.

'Tomory denounces talk of Gallery clique', NZH, 25 November 1964, p. 2.

'Travelling exhibitions and the Arts Advisory Council', AGMANZ newsletter, no. 15, May 1963, pp. 7-10.

Trevelyan, Jill, 'Leonard Mitchell: a cautionary tale', Art New Zealand 67, Winter 1993, pp. 85-87.

Trussell, Denys, Fairburn, Auckland: Auckland University Press and Oxford University Press, 1984.

Upton-Hughes, Betty, 'At home with Mr Tomory-The incoming man also has ideas', Star, 24 November 1955, p. 4.

Vincent, Mac, 'The Aucklander's Diary', Star, 20 November 1956, p. 6.

'The Aucklander's Diary', Star, 6 January 1965, p. 6.

Volkerling, Michael, with Christina Barton and Jenny Harper for McDermott Miller Limited, New vision: a critical view of New Zealand's visual arts infrastructure, Wellington: Creative New Zealand, 1998.

Walters, Gordon, 'A difficult time for artists', Landfall, vol. 185, April 1993, pp. 21-23.

Waterfield, Giles, 'The origins of the early picture gallery catalogue in Europe, and its manifestation in Victorian Britain', in Pearce, Susan (ed.), Art in museums, London and Atlantic Heights, NJ: The Athlone Press, 1995, p. 4273.

Webb, Peter, 'Notes from a fifties diary', Landfall, vol. 185, April 1993, pp. 16-21. 
Wedde, Ian, 'Colin McCahon: a question of faith', Landfall 206, November 2003, pp. 61-70.

Welch, Graham Kemble, 'Painters and pictures', Northland Magazine, no. 2, May 1958, pp. 11-13.

Westbrook, Eric, An exhibition of acquisitions 1952-1953, Auckland: Auckland City Art Gallery, 1953.

,'What should a gallery try to be?', Star, 24 November 1955, p. 4.

'Public art collections should not be haphazard', Star, 1 December 1955, p. 4.

'The artist's dilemma', Star, 8 December 1955, p. 4.

White, Eric W., The Arts Council of Great Britain, London: Davis-Poynter, 1975.

Williams, Mark, 'Crippled by geography? New Zealand nationalisms' in Murray, Stuart (ed.), Not on any map: essays in postcoloniality and cultural nationalisms, Exeter: University of Exeter Press, 1997, pp. 19-42.

Wilson, Arnold, 'Beginning to bubble', Landfall, vol. 185, April 1993, pp. 23-27.

Wilson, Rođney, 'Formal abstraction in post-war New Zealand painting', Art New Zealand 2, October-November 1976, pp. 13-20.

Worringer, Wilhelm, Abstraction and empathy: a contribution to the psychology of style [1908] (trans. Michael Bullock) London: Routledge \& Kegan Paul, 1967. 